\title{
Plazmonikus struktúrák tervezése, előállítása és alkalmazása
}

\author{
PhD értekezés
}

Sipos Áron

Témavezetö:

Dr. Csete Mária

egyetemi adjunktus

Fizika Doktori Iskola

Optikai és Kvantumelektronikai Tanszék

Szegedi Tudományegyetem Természettudományi és Informatikai Kar

Szeged

2012 


\section{Tartalomjegyzék}

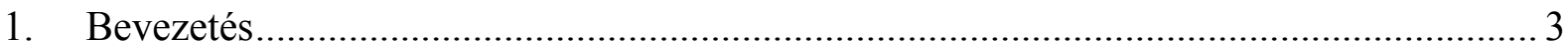

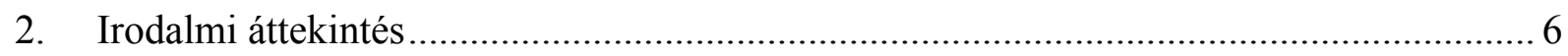

2.1. Periodikus és hullámhossznál kisebb struktúrák előállítására alkalmas módszerek .. 6

2.2. Periodikus és nano-plazmonikus struktúrák hatásai............................................ 9

2.3. Plazmonikus detektorok: biodetektálás ................................................................. 10

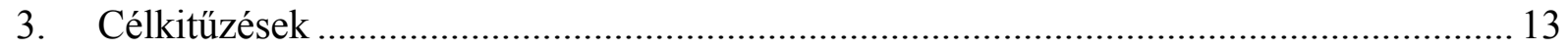

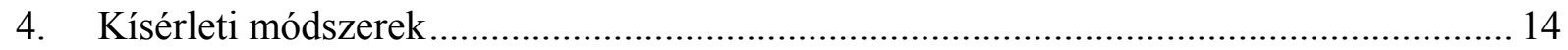

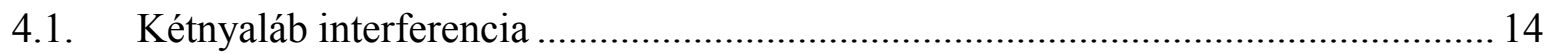

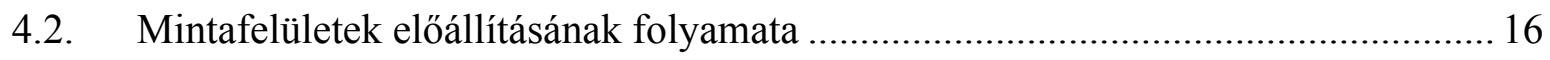

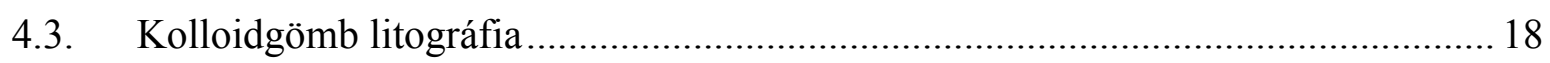

4.4. A felületek plazmon rezonancia spektroszkópiai jellemzése ................................ 19

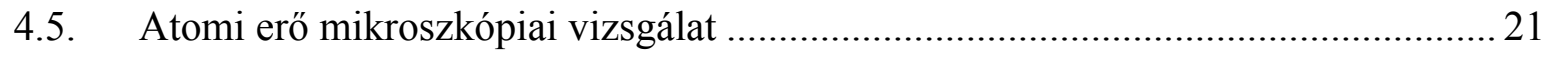

4.6. Pásztázó elektronmikroszkópos vizsgálat ............................................................ 23

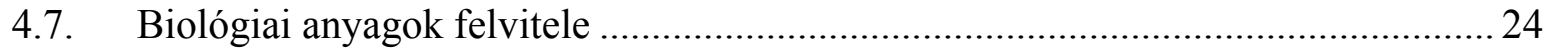

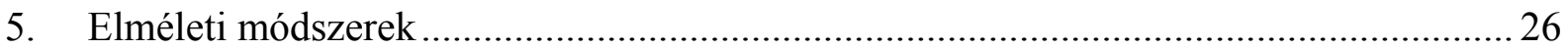

5.1. Végeselem módszeren alapuló modellezés ....................................................... 26

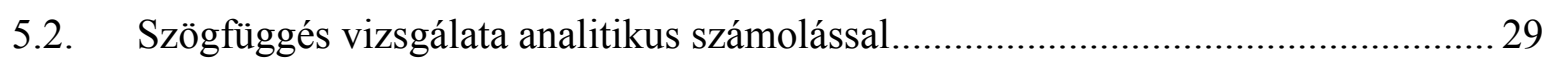

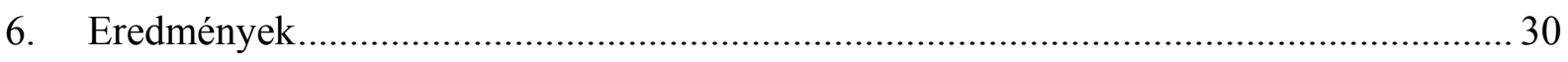

6.1. Plazmonikus struktúrák tervezése és előállítása..................................................... 30

6.2. Plazmonikus struktúrák plazmon rezonancia karakterisztikájának vizsgálata......... 47

6.3. Plazmonikus struktúrák alkalmazása a biodetektálás érzékenységének növelésére 58

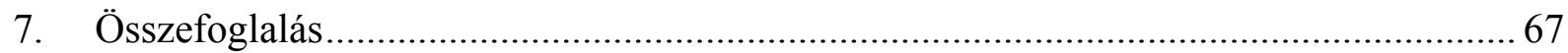

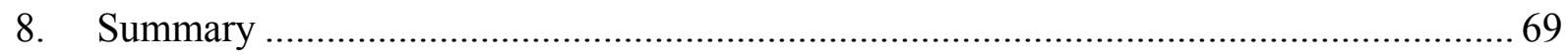

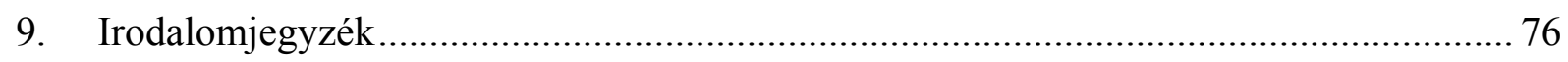

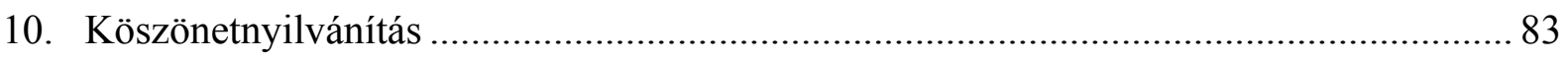

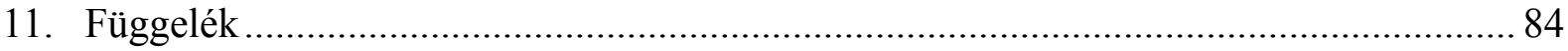




\section{Bevezetés}

Felületi plazmonnak nevezzük a dielektrikumok és vezetök (legtöbb esetben fém) határfelületén a kivilágító fény hatására létrejövő rezonáns kollektív elektromos töltésrezgést. A plazmonika, mint a fotonika plazmonokat tárgyaló ága ezen rezgések létrehozásával, karakterizálásával és befolyásolásával foglalkozik. A felületi plazmonok elektromos tere a felületre merőleges irányban, attól távolodva exponenciálisan csökken és kisebb a terjedési hossznál, ami a gerjesztő fény hullámhosszától és a fémfelület függően a néhány $10 \mathrm{~nm}$-től néhány $100 \mu \mathrm{m}$-ig terjed [1]. A miniatürizálás fejlődésével elérhetővé vált eléggé kisméretü struktúrák kialakítása, melyekkel lehetővé vált a plazmonok rezonanciájának befolyásolása. Kisméretü összetevőkből olyan plazmonikus struktúrákon alapuló eszközök állíthatók össze, amelyeknél a terjedésből adódó inherens veszteség a müködést nem gátolja.

A plazmonok egyedi tulajdonságain alapuló eszközök széles felhasználási kört fednek le, a hullámhosszal összemérhető periódusú plazmonikus struktúrák felhasználásával számos optikai elem [2], például kétdimenziós tükrök, nyalábosztók hozhatóak létre [3]. A plazmonikus struktúrák az adattárolásban [4], mikroszkópiában [5] és napelemek hatásfokának növelésére [6] is felhasználhatóak. Jelentős alkalmazási terület a biológiai anyagok detektálására alkalmas plazmonikus érzékelö-felületek kialakítása is [7], ezekkel egyetlen molekula kimutatása is elérhető [8]. A bioszenzorokban alkalmazott struktúrák jelentős hányadát a periodikus struktúrák adják, pl. fotonikus kristályokkal analóg plazmonikus kristályok [9] vagy nanoplazmonikus anyagok [10].

Azonos frekvenciájú foton és plazmon esetén a plazmon $\boldsymbol{k}_{\text {plazmon }}$ hullámvektora nagyobb, mint a fotoné, a felületi plazmon diszperziós relációja miatt, így a plazmonok keltése csak akkor lehetséges, ha ezt a különbséget valahogyan kompenzáljuk [11]. Erre a problémára több megoldás is létezik, a legelterjedtebb kísérleti eljárásban prizmát használnak erre a célra. A fény és a plazmon hullámvektora felületi modulációt, leginkább fémrácsot használva csatolható [12]. Rács segítségével a fény egy eszközbe be- és kicsatolható, így lehetőséget nyújt plazmonikus áramkörök létrehozására, ami a jelenleg elérhető mérethatároknál kisebb elektronikai eszközök felé mutat, ami a fény alapú számítástechnika előképe lehet.

Periodikus nanostruktúrák kézben tartható előállítása a sokrétű plazmonikai felhasználási terület szempontjából fontos, megfelelő mintázatokkal több tudományos és technikai kérdés megoldható. A klasszikus pásztázó elektronnyaláb technikával nagy felbontással lehet tetszőleges struktúrát létrehozni egy felületen, de a lassú megmunkálás és a 
meglehetősen nagy költség miatt ez a technika széles körben nem tudott elterjedni [13]. A gyakorlati felhasználás szempontjából sokkal praktikusabbak a nagy felületek megmunkálására egy lépésben alkalmas módszerek.

A lézeres anyagmegmunkálási eljárások párhuzamos technikák, azaz egy lépésben viszonylag nagy felületen alkalmazhatóak az anyag átstrukturálására. Lézeres litográfiai eljárásokban a felület maradandó módosítása a lézer paramétereitől és az alkalmazott anyagtól függően lehet abláció (anyag eltávolítással és/vagy átrendezéssel járó folyamat), vagy fotokémiai változás az adott anyagban (sugárzásra érzékeny vékonyréteg, fotoreziszt), vagy ezek kombinációja. Az ablációs eljárások általában egylépéses viszonylag gyors és egyszerübbnek tekinthető technikák, de bonyolultabb struktúrák előállítása ezzel a módszerrel is nehézkes. Összetett szerkezetű felületek állíthatóak elő rezisztek többlépéses litográfiájával. A lézeres többlépéses litográfiás eljárások a legtöbb esetben bonyolult felszerelést és nagy szaktudást igényelnek, megfelelő méretű megmunkálás pedig nagyfokú tisztaszobával rendelkező laboratóriumokban valósítható meg, ami nem mindenhol áll rendelkezésre. Lézeres interferencia litográfia alkalmazásával hullámhossz nagyságrendü struktúrák állíthatók elő [14]. A lézeres eljárások széles körben alkalmazhatóak tudományos és ipari területen. Azonban ezen alkalmazások közös hátránya, hogy a nanométeres tartományba eső felületmódosítás a diffrakciós határ miatt csak nehezen befolyásolható önszerveződő folyamatok segítségével lehetséges [15].

Jól kontrollálható viszont a lézeres kolloidgömb litográfiával létrehozható felület. A módszer lényege, hogy a megmunkálandó felületre különböző technikákkal kolloid gömböket visznek fel, ezek a rájuk eső lézerfényt fókuszálják és módosítják a szubsztrát felületét. A legtöbb esetben a gömbök szorosan illeszkedő hatszöges elrendezésben monorétegben helyezkednek el a felületen, így a kivilágítás ezt a szimmetriát örökíti tovább. A felület megmunkálásának eredménye a gömb és a hordozófelület anyagától, a kivilágító lézer paramétereitől függ. Többlépcsős eljárásokban a kolloid gömböket vagy az azokkal megmunkált felületet további anyaggal vonják be és úgy állítanak elő kisméretü objektumokat, de ezek a mintázatok a szorosan illeszkedő hatszöges mintázat szimmetriáját átörökítik. Ettől eltérő mintázat csak maszkfelületekkel való tereléssel vagy a gömbök közötti kémiai erők befolyásolásával érhető el.

A plazmonikus detektorok kutatásának eredményeként az első plazmon rezonancia spektroszkópián alapuló detektor 90-es évek elején jelent meg a kereskedelemben. A svéd Biacore céget több más követte az évek folyamán, így a folyamatos fejlesztéseknek köszönhetően az allergénektől és tumormarkerektől kezdve (Spreeta) antitesteken keresztül 
(Autolab Esprit) baktériumokig (Biacore 3000) biológia anyagok széles skálája mutatható ki. Az ilyen típusú eszközök általában egy áramlási csőben keringetett megfelelő koncentrációjú anyag optikai tulajdonságait vizsgálják meg és előzetes hitelesítés alapján következtetnek a mennyiségre. Többcsatornás készülékek is léteznek, ezekkel egyszerre akár több mérés is végezhető egy időben, de ezeknél viszonylag bonyolult a mérendő anyag megfelelő keringetése.

Ezen eszközöknél egyszerübb lehet az úgynevezett lab-on-chip koncepción alapuló plazmonikus detektor, amikor egy felületen akár többféle, de jól meghatározott anyag kimutatására célzottan kifejlesztett detektorrészt helyeznek el, és a fény ezekbe való be- és kicsatolása pl. plazmonikus struktúrákkal megoldott. Ezek akár szárazon is működhetnek és litográfiás eljárásokkal gyorsan és kis költséggel nyomtathatóak lehetnek.

Munkám során a fent kifejtett elgondolás mentén azt vizsgáltam, hogy fém és polikarbonát felületen előállított rácsok hogyan alkalmazhatóak biodetektálásra. Az egyszerü rácsfelülettől a bonyolultabb, részletgazdagabb felületek előállítása felé haladva kompozit maszk alapú kolloid litográfiás elrendezéssel kísérletileg vizsgáltam, hogy lineáris struktúra hogyan állítható elő és a mintázat méretparaméterei hogyan változtathatóak. Végeselem modellezéssel a maszkos elrendezésnél kevesebb lépésből álló kombinált litográfiás elrendezés lehetőségeit tanulmányoztam, mellyel az előző megoldásnál egyszerübb és szintén szabályozható módon állítható elő lineáris struktúra. A plazmonikus struktúrákat tanulmányozva kerestem, hogy mely tulajdonságok esetében alkalmasak sztreptavidin detektálására.

Dolgozatom a következő fejezetekre tagolható: a bevezető utáni 2. fejezetben az irodalom alapján a periodikus struktúrák elöállítására alkalmazott módszereket, eszközöket, majd a struktúrák hatását és felhasználását mutatom be. A célkitüzéseket a 3 . fejezetben fogalmazom meg, majd a 4. fejezetben a kutatás során alkalmazott kísérleti, az 5 . fejezetben az elméleti módszereket ismertetem. A 6. fejezetben foglaltam össze az elért eredményeket, amit a magyar és angol nyelvü összefoglalás (7., 8. fejezet), majd az irodalomjegyzék követ. 


\section{Irodalmi áttekintés}

\subsection{Periodikus és hullámhossznál kisebb struktúrák előállítására alkalmas módszerek}

Az alábbiakban röviden áttekintem azokat az eljárásokat, melyekkel megfelelően kisméretű, periodikus mintázat állítható elö, kiemelve az egyes módszerek előnyeit és hátrányait. Ezek alapot adnak a megfelelő módszer kiválasztására, mellyel a detektorfelületként használni kívánt felület elöállítható.

Az optikai litográfiás eljárások széles körben alkalmazottak kisméretü struktúrák előállítására a tudományban és az iparban egyaránt. Ezek az eljárások a legtöbb esetben maszkok mintázatának a felületre való átvitelén alapulnak. Legegyszerübb esetben úgynevezett kontaktmaszkot alkalmaznak, azaz egy megfelelö mintázattal lefedik a megmunkálandó felületet, majd ezen keresztül történik a kivilágítás. A maszk által ki nem takart részek maradnak meg vagy távolíthatók el megvilágítás után, attól függően, hogy pozitív vagy negatív rezisztet alkalmaznak, de már a maszk kialakítása a felületen is feladat ebben az esetben. Ha nemcsak egy, hanem többféle mélységü mintázat elkészítésére van szükség, akkor újramaszkolással és kivilágítással további profilmélységek képezhetők, ez megfelelő technikát és viszonylag hosszú időt vesz igénybe.

Az elérhető feloldás a kivilágító fény hullámhosszától és az alkalmazott leképező rendszer numerikus apertúrájától függ. Ez az oka annak, hogy a félvezető iparban alkalmazott litográfiás berendezések egyrészt a nagy megmunkálandó felület, másrészt az alkalmazott, jellemzően UV hullámhosszon való müködés miatt nagyméretü, speciális anyagú, bonyolult optikai elemeket igényelnek, ami a költségeket jelentősen növeli.

Litográfiás technikák csoportjába tartozik a részecskék irányított nyalábját felhasználó elektron- vagy ionnyalábos litográfiai eljárás is. Az elektronnyalábos litográfia előnye, hogy akár néhány nanométeres feloldás is elérhető a segítségével, de hátránya a fényt használó eljárásokkal szemben magas ára és a lassú megmunkálás is. Ionnyalábos litográfiával akár fém rácsok is előállíthatók, azonban ez esetben is hátrány a berendezés bonyolultsága, és hogy a fémfelületen maszkolással alakítható ki a megfelelő mintázat [16].

Egyszerü és gyors eljárás a lenyomat-készítéses technika, mellyel a viszonylag puha megmunkálandó felületbe elöre gyártott mintázatú kemény maszkot nyomnak bele és annak negatívja használható fel. Ez az eljárás gyors és kis költséggel jár, de fémstruktúrák direkt kialakítására nem alkalmas, csak egy létrehozott mintázat utólagos bevonásával [17]. 
A száraz maratási eljárások lényege, hogy a reaktív plazma a felülettel fizikai kölcsönhatás mellett megfelelő anyagválasztás esetén kémiai reakciót is eredményez, ezzel a maratás sebességét meggyorsítja. A módszer során elektromágneses térrel plazmát hoznak létre, melynek ionjait az elektródákon alkalmazott feszültséggel a megmunkálandó felület felé gyorsítják. Ez esetben is maszkkal fedett felület szabad részeit a részecskék megmunkálják. A módszer itt is többlépéses és megfelelő vákuumtechnikát is igényel [18].

A direkt lézeres eljárásokkal az előző módszerektől eltérően akár egy lépésben is létrehozható a felületi szerkezet. Fémek esetén legtöbbször egy, már meglévő maszk erős kicsinyítéssel való leképezéssel hozható létre a hullámhossz nagyságrendjébe eső méretü felületmódosítás [19]. A kontaktmaszktól eltérően a leképezés lehetővé teszi a nagyobb méretű mestertárgy használatát, ami a nagyobb nyalábátmérőnek (kisebb teljesítménysűrüség) köszönhetően a megmunkálandó felület anyagával megegyező is lehet, mivel a roncsolási küszöböt a lefókuszált nyaláb intenzitása éri el. Itt az optikai leképező rendszer és a megfelelő maszk kiválasztása és elhelyezése érdemel figyelmet, ezek a létrehozott mintázat minőségét erősen befolyásolják. Kis méretek eléréséhez jó tulajdonságú objektívek szükségesek, ezek is meglehetősen költségesek lehetnek. A leképezésnél egyszerübb módszer, hogy a lézernyalábot megfelelően fókuszálják, és a mintafelület felett a kívánt irányban mozgatják, a fókuszálhatóság határa és a lassúság miatt ennek az eljárásnak is megvannak a feloldásbeli korlátai.

Periodikus, a kivilágító lézer hullámhosszának tartományába eső mintázat a felület roncsolási küszöbe alatti teljesítménysürüséggel is előállítható. A lézerrel indukált periodikus felületi struktúrák (laser induced periodic surface structure, LIPSS) változatos anyagú felületen, félvezetökön [20] és polimereken is létrehozható [15,21]. Az így létrehozott struktúrák szintén a hullámhossztartományba esnek, és a létrehozásuk rendszerint kis hullámhosszon történik. A periódus függ a felület anyagától, a hullámhossztól, a keletkező hullámos felület irányultsága pedig a polarizációval hozható összefüggésbe. Bár a mérettartomány megfelelően kicsi, az önszerveződő folyamatok miatt a mintázat nem eléggé rendezett, és a periódus befolyásolása is nehézkes.

Kontrollálható módon állítható elő rácsfelület lézeres kétnyaláb interferenciával. Ebben az esetben nincsen szükség leképező maszkra, az interferenciamintázat megfelelő vizibilitása és teljesítménysürüsége esetén a mintázat a felületbe írható. A technika ns-os impulzushosszú [22] és fs-os [23, 24] lézerekkel rács kialakítására alkalmas akár fém multirétegeken is. A rövid impulzusok előnye, hogy a hőhatás kisebb befolyása miatt nagyobb felületi struktúra állítható elő. A felbontás ez esetben is a kivilágító fény hullámhosszával 
mérhető össze. Atomi erő mikroszkópiás méréssel kimutatható, hogy a direkt megmunkálás mellett a lézerfény okozta fázisátalakulásnak is szerepe van a felület kialakításában, ezt a kihülés után kialakuló szemcsék, cseppek igazolják [25]. A kétnyalábos interferencia nemcsak fémeken, hanem dielektrikum felületen is jól alkalmazható, amennyiben megfelelő abszorpciója van az anyagnak a kivilágító fény hullámhosszán.

Hexagonális szimmetriájú mintázat hozható létre lézeres kolloid litográfiával. melyet széles körben alkalmaznak jól meghatározott alakú, méretü és rendezett eloszlású nanorészecskék előállítására [26]. Az eljárás eredménye általában egy hatszöges mintázatot mutató lyuksereg. A technika a diffrakciós határnál kisebb méretü objektumok előállítására is alkalmas [27, 28]. Dielektrikum gömbök lézeres kivilágítása esetén azok fókuszáló hatásának köszönhetően a gömbök alatti felületen nagy elektromágneses térnövekedés érhető el, mely a gömb méretével és a kivilágító fény hullámhosszával hangolható [29]. Ferde beeséssel homogén kivilágítás esetén is változatos alakú nano-objektumokból álló mintázat hozható létre [30]. Dielektrikum gömbök felhasználása a kolloid litográfiában gyakoribb, de a fém kolloid részecskék is szerepet kapnak, köszönhetően a felületükön létrejövő plazmon rezonanciának, mely nagy közeltérbeli intenzitás kialakulását teszi lehetővé, ami a gömbátmérővel és a gömböket körülvevő közeg törésmutatójával hangolható [31].

Kis laterális kiterjedésű objektumokból álló, de nem hatszöges elrendezésű mintázat elérésére többféle lehetőség is van. Egyik ilyen eljárás előre megtervezett mesterstruktúrák kialakítása a felületen, amelyek meghatározzák a kolloid gömbök csoportokba vagy akár rendezett sorokba való elhelyezkedését a felületen [32]. Láncszerüen felfüzött kolloid gömbsor érhető el kolloid gömbök felületének anizotróppá tételével, majd ezek mágneses erőtérbe helyezésével [33]. Ezek az ún. Janus-kolloidok két szimmetrikus, de eltérő tulajdonságú félből állnak, melyek többféleképpen előállíthatóak, például dielektrikum gömb egyik felének fém vékonyréteggel való bevonásával. A két különböző térfél hatására a részecskék egyfajta dipólusként müködnek, külső erőtér vagy csak a gömb mentén fellépö töltéskülönbség miatt mozgathatóakká és rendezhetőekké válnak [34]. Kolloid monorétegek periodikus mintázattal való kivilágítását is vizsgálták, de a módszer a kolloid gömbméreteknél jóval nagyobb periódusú maszkok használatával történt, ennek következtében a felületen nagy kiterjedésű megmunkált és megmunkálatlan felület volt megfigyelhető, amelyen belül a hatszöges szimmetria maradt domináns $[35,36]$. 


\subsection{Periodikus és nano-plazmonikus struktúrák hatásai}

Periodikus és nanométeres struktúrák nagy hatással vannak az őket tartalmazó fémdielektrikum határfelületek felületi plazmon rezonanciájára (surface plazmon resonance, SPR). A plazmon gerjesztéséhez az eltérö hullámvektorú plazmon és foton csatolására van szükség. Ez többféleképpen történhet, legegyszerübb módon ez egynél nagyobb törésmutatójú anyagon keresztül való kivilágítással oldható meg, az $n$ törésmutató a hullámvektort növeli ami ilyen módon eléri a plazmon hullámvektorának nagyságát. A csatolásra két egyszerü, prizmán alapuló megvalósítást ismerünk. A Kretschmann-féle elrendezésben prizmára párologatott fémréteg és a levegő határfelületén hozható létre plazmon, az ún. Ottokonfigurációban a prizma és a fémréteg között vékony levegőréteg található [37, 38]. A Kretschmann-féle elrendezés vékony filmeken alkalmazható, az Otto-konfiguráció viszonyt tömbanyagok felületén is használható plazmonokba való csatolásra. Mindkét esetben a csatolás jó hatásfokának elérésére a beesési szög és a fémréteg vastagsága is optimalizálandó. Más módszer szerint a felületen található konkáv vagy konvex objektumon való szóródással is lokális plazmon gerjeszthető [39].

Egy elektronhullám valódi kristályban való terjedése hasonlóságot mutat az elektromágneses hullám periodikus struktúrában való terjedésével. A periodikusan változó optikai tulajdonságokkal rendelkező anyagokat fotonikus kristálynak nevezzük [9]. A félvezetők analógiájának megfelelően ezekben is ún. fotonikus tiltott sávok jelennek meg. A legegyszerübb gyakorlati megvalósítás egy fémrács felülete, amely szintén tekinthető fotonikus kristálynak. Ezt bizonyítja, hogy periodikus felület esetén a rács és a rácsvektor segítette foton hullámvektor csatolódni képes, és a hullámhosszfüggő reflektanciát mérve a spektrumgörbén tiltott sávra jellemző alak figyelhető meg [40]. A rács nemcsak csatolásra képes, hanem terjedése során a plazmon a felületi mintázattal kölcsönhat, a diszperziós relációja változik, így a fotonba visszacsatolódhat. A rácson való szóródás a rezonanciacsúcs kiszélesedését okozhatja, így a kiszélesedés vizsgálatával a felület érdessége jellemezhető [41]. A terjedés hosszát a közeg is befolyásolja, szimmetrikus közegben vékony filmen a terjedés hossza jóval nagyobb lehet, mint asszimmetrikus félvégtelen dielektrikum között elhelyezkedő fémfilm határfelületén elérhető távolság [42].

A plazmonok és a felületi struktúrák kölcsönhatása hasonlóságot mutat az optikai elemekkel befolyásolt fény terjedésével, ennek alapján bevezethető a plazmonoptika fogalma. Az elgondolás nagy elönye, hogy a kis lecsengési hossz miatt a terjedés gyakorlatilag kétdimenziósnak tekinthető. 
A plazmonok terjedésének befolyásolására sokféle eszközre lehet szükség, melyek betöltik a terelőelem szerepét, miközben a minimálisra csökkentik a szórásból adódó veszteségeket. A felület adott területrészén az optikai tulajdonságok befolyásolásával vagy a felület geometriájának változtatásával létrehozhatók az optikából ismert elemek analógjai, például interferencia valósítható meg [43]. Megfelelően méretezett kör alakú szerkezetek szintén jól koncentrálhatják a közeltérben a plazmonokat. Nanolyukak és nanorészecskék plazmon lokalizációt hoznak létre, ezáltal közelükben nagy térbeli intenzitás jöhet létre [44-47].

Érdekes jelenség a vékony filmekbe írt lyukmintázatokon történő extraordinárius transzmisszió [44]. Extraordinárius transzmisszióról akkor beszélhetünk, ha a lyukak összfelületének és a teljes felületnek a hányadosával szorzott beeső intenzitásnál nagyobb fény figyelhető meg a lyukas film túloldalán. A lyukmintázatoknál megjelenő extraordinárius transzmisszió azt mutatja, hogy nemcsak a lyukakra, hanem a fémre eső fény is át tud haladni a megmunkált felületen, azaz a felületi nanostruktúra antennaként müködve a plazmonok segítségével becsatornázza az elektromágneses energiát a lyukakba [48-50]. A transzmissziós spektrum a lyukak méretével és periódusával finoman hangolható [48].

Rácsok szögfüggő plazmonrezonanciás vizsgálatakor a rácskarcolatoknak a fénybeesési síkjával bezárt azimuthális irányától függő intenzitásváltozás tapasztalható [51], A fém filmen elhelyezkedő dielektrikum rács is rácscsatolást hoz létre, és ez kettős rezonancia-minimumok megjelenésével jár [52].

\subsection{Plazmonikus detektorok: biodetektálás}

A dielektrikum-határfelületen megjelenő erős elektromágneses tér miatt a plazmon rezonancia karakterisztika érzékenyen függ az optikai vastagságtól [53]. A különböző plazmon spektroszkópiai módszerek az optikai változások függését hullámhossz, beesési szög polarizációváltozás függvényében vizsgálják [54, 55].

Az állandó hullámhosszon történő szögfüggő mérés megfelelő eljárás a fémet bevonó dielektrikum réteg vastagságának meghatározására [56]. A mérés nagy érzékenysége alkalmas a kis vastagságváltozás kimutatására, azaz kis anyagmennyiség eltávolítása vagy a felületre való kitapadása is detektálható [7]. A felületen található fém részecskék nagy közel-terüknek köszönhetően érdekes változást okoznak a plazmon rezonancia karakterisztikában, amelynek vizsgálata esetükben a hullámhosszat változtatva állandó szög mellett történik [40,45]. Fémmel bevont rácsfelületek felületi plazmonrezonanciája szintén jól használható biodetektorként [57]. 
A detektorok általános elve, hogy a plazmon rezonancia spektrumvonalakat vagy szögfüggő minimumhelyeinek változását monitorozza. Ismert anyag és koncentrációval való hitelesítés után kis mennyiségek pontos kimutatására alkalmasak.

A biológiai minták mérése oldott állapotban történik, egyrészt száraz körülmények között tulajdonságaik megváltozhatnak, másrészt legtöbbször a mérés célja éppen meghatározni pontos koncentrációjukat egy adott oldatban. Emiatt a felületi plazmonrezonancia aktív fémrétegei a mérés során sérülhetnek, ezért bio-kompatibilitásuk elősegítésére a felületre biológiai anyagokat kötnek ki [58]. A rácscsatolást szögfüggő mérésben alkalmazó detektorok érzékenysége egyezik a prizmával történő csatolást használó berendezésekével [59].

A részecske körül lokalizált elektromágneses tér lecsengési hossza összemérhető a biomolekulák méretével, így a módszer kinetikai mérésekre is felhasználható. Szintén vizsgálták periodikusan elhelyezett ezüst nanorészecskék hatását, a lokalizált plazmon rezonancia spektroszkópiával az ezekhez csatolt biomolekula hullámhosszfüggő érzékelése valósítható meg [60]. A plazmon-biomolekula csatolás ezüst felületbe mart nano-lyukakra is tanulmányozták vizsgálták [61]. A részecskék körüli erős térnövekmény felületerösített Raman spektroszkópiára (Surface Enhanced Raman Spectroscopy, SERS) is alkalmas [62].

Több kutatás is kimutatta, hogy nemesfém nanorészecskék hozzáadásával a mért plazmonrezonanciás jel jelentősen megnövelhető $[63,64]$.

A plazmon rezonancia spektroszkópián alapuló bioszenzorok érzékenysége a rezonanciagörbén mérhető változás és az azt okozó koncentrációkülönbség vagy anyagmennyiség arányával jellemezhető. A módszer előnye, hogy akár érzékeny biológiai anyagok is mérhetőek hozzáadott radioaktív vagy fluoreszcens jelölés nélkül. Az elérhető felbontás szintén fontos jellemzője a mérési elrendezésnek. Mivel a plazmonba csatolt fény intenzitásváltozását figyelik, a mérhető fény ingadozása, zaja rontja az érzékenységet. Ennek forrása lehet a megvilágító fényforrás, valamint a forodetektor fény-elektromos jel átalakítása során fellépő zaj [65]. A zajszint a mért jelek időbeli átlagolásával, vagy ha a detektorfelület lehetővé teszi, akkor a szenzorchip oszlopairól nyert jel átlagolásával csökkenthető.

Több kereskedelmi forgalomban lévő méröberendezést fejlesztettek a plazmonrezonanciás érzékelés elvére alapozva [66]. Ezek az eszközök gyártótól függően általában robosztusak, viszonylag költségesek, képzett személyzet müködteti laboratóriumi körülmények között. Ezek egyik felhasználási köre az élelmiszeripari minőségi és egészségügyi ellenőrzés. A Texas Instruments által gyártott Spreeta berendezéssel Escherichia coli baktérium volt kimutatható [67], vagy antibiotikum nyomai tejben [68]. A fent felsorolt 
eszközök alkalmasak továbbá hormonok, allergén anyagok, fehérjék, tumor markermolekulák, orvosi diagnosztikában jelentéssel bíró antitestek, gyógyszerek és gyógyszerek kiváltotta antitestek, szívrohamra jellemző szívizomsérülést jelző antitestek kimutatására is.

A fent bemutatott széles felhasználási kör miatt a plazmonikus detektorfejlesztés távlati célja lehet, hogy könnyen hordozható, terepi körülmények között is felhasználható, egyszerüen kezelhető eszközök jelenhessenek meg. Ez irányba tett lépésnek tekinthető a továbbiakban bemutatandó munkám, mivel megfelelö detektorfelülettel a mérés egyszerüsíthető, gyorsítható és adott anyagra érzékennyé tehető. 


\section{Célkitüzések}

A periodikus és nanométeres plazmonikus struktúrákra vonatkozó irodalom áttekintése alapján levonható a következtetés, mely szerint a periodikus és komplex, azaz a diffrakciós limit alatti mérettartományba eső komponensekből felépülő, ugyanakkor a fény hullámhosszával összemérhető periódussal rendelkező struktúrák jelenleg is nagyon széles felhasználási köre még tovább bővíthető. Az ilyen típusú komplex struktúrák létrehozására alkalmas technikák általában időigényesek és a legtöbbször jelentős anyagi ráfordítás sem elhanyagolható szempont. Mindezek alapján szükségesnek látszik új periodikus és komplex plazmonikus struktúrák létrehozására alkalmas eljárások kidolgozása és ezen eljárások megvalósításához új kísérleti elrendezések összeállítása.

Az egyes nanofotonikai és nanoplazmonikai felhasználási területek speciális komplex struktúrákat igényelnek. Számos elméleti módszer alkalmas a felületi plazmonikus struktúrák optikai tulajdonságokra gyakorolt hatásának leírására. A létrehozott nano- és plazmonikus struktúráknak gyakorlati felhasználását megelőzi hatásuk kísérleti és elméleti módszerekkel történő vizsgálata, az előállított felületek biomolekula detektálásra alkalmazhatóságának tesztelése.

Ennek fényében a következő célokat tüztem ki:

Első célom vizsgálni a lézeres besugárzással létrehozható fémrácsok arany-ezüst rétegvastagságaitól függő felületi minőségét, mely a bio-detektáláshoz szükséges ideális rétegkombináció meghatározásához szükséges. Célom kimutatni ezen felületek felületi plazmon rezonancia spektroszkópiás (surface plasmon resonance spectroscopy, SPRS) vizsgálatával, hogy a fémrácsok plazmonikus bio-detektorként alkalmazhatók.

Második célom meghatározni azokat a lézeres strukturálási paramétereket, melyekkel bimetál filmre felvitt polimer réteg felületi topográfiája hangolható. SPRS módszerrel vizsgálni kívántam polikarbonát rács bio-detektorként való alkalmazását, és hogy hogyan változik a sztreptavidin detektálásának érzékenysége a vonalas polikarbonát rácsra felvitt molekulához kötött arany részekék esetén.

Harmadik célom polimer mesterrácsra forgatva bevonással felvitt kolloid gömbökön alapuló kompozit maszk készítése, és ennek homogén lézeres kivilágításával vonalas elrendezésü lyukmintázat létrehozása. Tervezem a lineáris lyukmintázat dielektrikumok detektálására alkalmas szenzorfelületként való alkalmazhatóságának tesztelését.

Negyedik célom végeselem modellezéssel az arany filmre helyezett arany és Stöberkvarc kolloid részecskékből képezett monorétegek két interferáló lézernyalábbal kivilágításának vizsgálata, a létrejövő mintázat tulajdonságainak a monoréteg és a megvilágítás paramétereitől való függésének meghatározása. Tervezem az így létrehozható lineáris komplex struktúrák plazmonikus hatásának elméleti tanulmányozását. 


\section{Kísérleti módszerek}

\subsection{Kétnyaláb interferencia}

A kétnyaláb interferencia jól alkalmazható különböző felületeken rácsok előállítására. $\mathrm{Az}$ irodalom áttekintése során leírt más módszerekkel szemben előnye, hogy egyszerübb elemekkel, költséghatékonyabban, rugalmasan változtatható módon állítható elő megfelelő periódusú struktúra. Két koherens, azonos hullámhosszú, ugyanazon beesési síkban adott szögben találkozó nyaláb interferálva csíkrendszert hoz létre, melynek $p$ periódusát a következő képlettel lehet meghatározni:

$$
p=\frac{\lambda}{2 \sin (\theta / 2)}
$$

ahol $\lambda$ a közegbeli hullámhossz, $\theta$ pedig a két nyaláb által bezárt szög. A nyalábok beesési szögének változtatásával a kívánt periódus elérhető, hangolható.

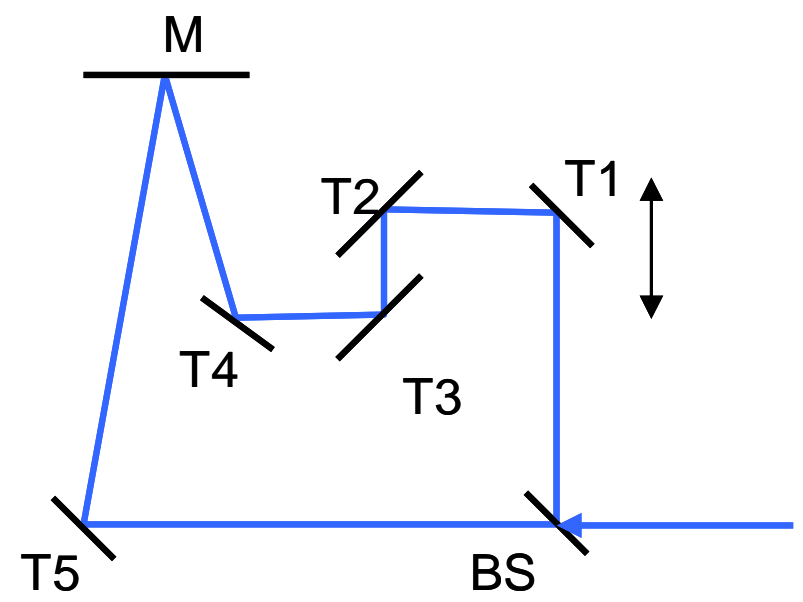

1. ábra. Kétnyaláb interferencia megvalósítása tükrökkel ( $\mathrm{M}$ - minta, $\mathrm{BS}$ - nyalábosztó, T - tükrök )

A kísérletek során a fenti módszernek kétféle megvalósítását alkalmaztam. Az első elrendezés alkalmazása során tükrök segítségével hozunk létre interferenciamintázatot a megmunkálandó felületen (1. ábra). Előnye, hogy az interferáló sugarak szögének változtatásával a létrehozott periódus is hangolható, valamint a tükrök viszonylag nagy roncsolási küszöbe lehetővé teszi nagyobb megmunkáló energiasürüség használatát. Hátránya, hogy a beállítás nehézkes lehet, megfelelő koherenciahosszúságú impulzus szükséges ahhoz, hogy a két nyaláb közti úthossz-különbség beállítása technikailag ne legyen túlságosan nehéz. Ez az elrendezés a mechanikai rezgésekre is meglehetősen érzékeny, egy hosszas kivilágítás során bekövetkező hőmérsékletváltozás pedig befolyásolja az ideális 
mintasík (azon sík, ahol a nyalábok a legnagyobb felületen és legjobb vizibilitással fednek át) helyzetét. Ezek kiküszöbölését a rövidebb megmunkálási idő alkalmazásával érhetjük el.

A másik alkalmazott megoldás a 2. ábrán vázolt mesterrácson alapuló elrendezés volt [69].

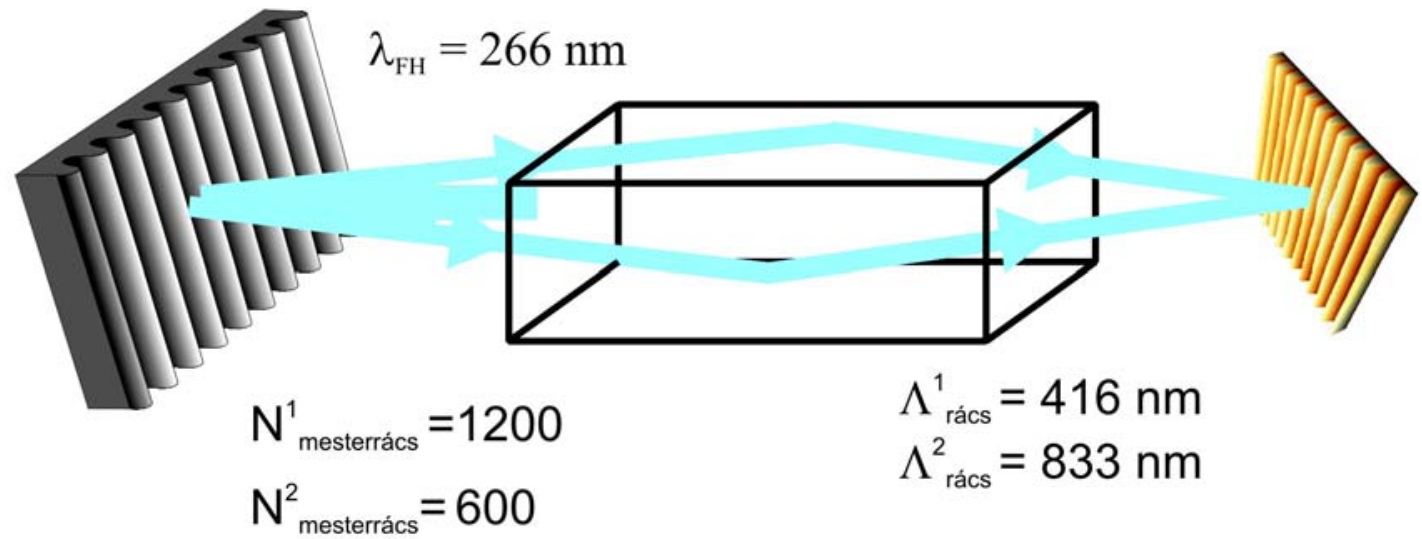

2. ábra. Mesterrácsos elrendezés elvének bemutatása

A módszer lényege, hogy egy mesterrácson létrejövő diffrakció első rendjeit egy téglalap alapú kvarchasábba vezetjük be, a nyalábok pedig a hasáb oldalfalain való teljes visszaverődés után találkoznak a mintafelületen és abba a mesterrács periódusának felével megegyező periódusú rácsot hoznak létre. A módszer nagy előnye, hogy egy interferometrikusan sima kvarctömbbel elérhető az a fontos feltétel, hogy a felhasznált két diffrakciós rend közti optikai úthossz gyakorlatilag nulla legyen, így a módszer rövid koherencia-hosszúságú lézereknél is könnyen alkalmazható. Hátrányt jelent azonban, hogy a mesterrács egyértelműen meghatározza a létrehozható mintázat periódusát, így a periódus változtatása csak a mesterrács cseréjével érhető el. Korlátozza a felhasználhatóságot az is, hogy a rács roncsolási küszöbének valamivel magasabbnak kell lennie a megmunkálandó felület küszöb-energiasűrüségénél, még akkor is, ha azt az ideális esetet tekintjük, amikor a rácsfelületre beeső nyaláb teljes energiája az első rendekbe esik. Mindezen hátrányok ellenére, ha előre jól meghatározható a létrehozni kívánt periódus, akkor a mesterrács és a kvarctömb geometriájának gondos megválasztásával olyan egyszerü és kis alapterületü elrendezés hozható létre, mellyel gyorsan és könnyen nagyszámú minta legyártható.

A fenti előnyöket és hátrányokat figyelembe véve a tükrök alkalmazásán alapuló módszerrel a nagyobb energiasűrüséget igénylő fémfelületeken, míg a rácsot alkalmazó elrendezéssel a polikarbonáttal bevont mintákon állítottunk elő periodikus struktúrákat. 
Az alkalmazott fényforrás egy impulzusüzemü Nd:YAG (Spectra Physics Quanta Ray Pro, $10 \mathrm{~Hz}$ ) lézer volt, negyedik harmonikusának $\lambda_{\mathrm{SH}}=266 \mathrm{~nm}$ hullámhosszú, $\tau=10 \mathrm{~ns}$ impulzushosszú fényével munkáltuk meg a mintafelületet.
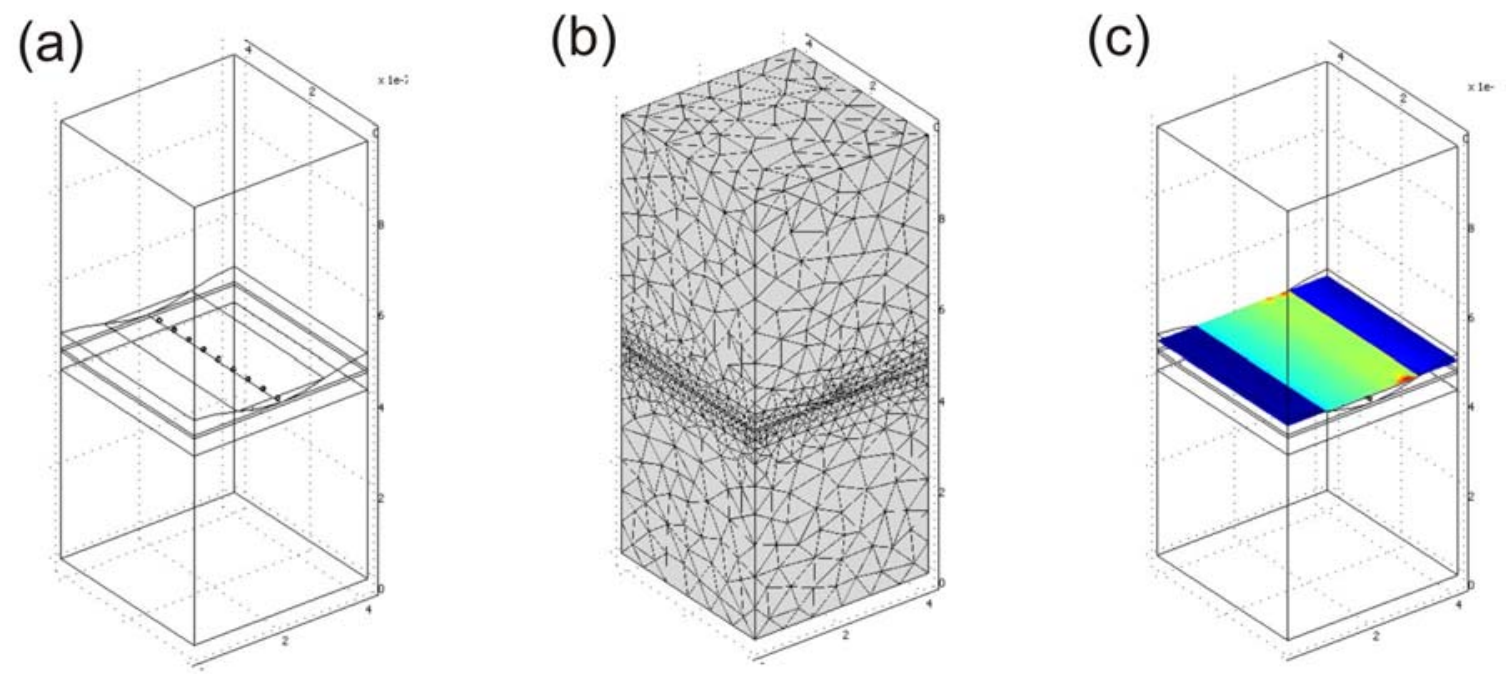

3. ábra. (a) s-polarizált, (b) p-polarizált és (c) kétfázisú s-polarizált kivilágítás

Különböző kivilágítási módokat alkalmaztunk az egyes esetekben: fémrácsoknál spolarizált fénnyel végeztük a megmunkálást (3. (a) ábra) polimer rácsoknál az s-polarizáció mellett p-polarizált fényt is alkalmaztunk, valamint az s-polarizált fénnyel keresztezett rácsokat is létrehoztunk a minta $60^{\circ}$-os elfordításával (3. (b) és (c) ábra). Fém-dielektrikum felületek sorozatos kivilágítása lézer indukált periodikus felületi struktúrák (laser induced periodic surface structure, LIPSS) kialakulásához vezet a szórt nyaláb interferencia következtében [15]. A LIPSS és az interferenciamintázat együttes jelenléte érdekes felületi topográfia kialakítását teszi lehetővé (6.2 alfejezet, 27. ábra, [T2]).

\subsection{Mintafelületek előállításának folyamata}

A felhasznált mintafelületek alapja NBK7 típusú interferometrikusan sima üveghordozóra (Geodasy és EKSMA) vákuumpárologtatott (Optilab Kft.) arany és ezüst nemesfém réteg volt, a legtöbb esetben ezüst-arany bimetál réteget alkalmaztunk különböző rétegkombinációkban. Az ezüst jó plazmonikus tulajdonsággal rendelkezik, de erősen oxidálódik a szabad levegőn, ezért az ezüstrétegre párologtatott, ellenállóbb arany réteg egyrészt védi a környezeti hatásoktól előbbit, másrészt jó hővezetésének és a megmunkáló lézer hullámhosszán való nagyobb abszorpciójának köszönhetően elősegíti annak megmunkálását. A fémrétegek vastagságait az adott alkalmazás céljainak megfelelően választottuk meg [T1]. 


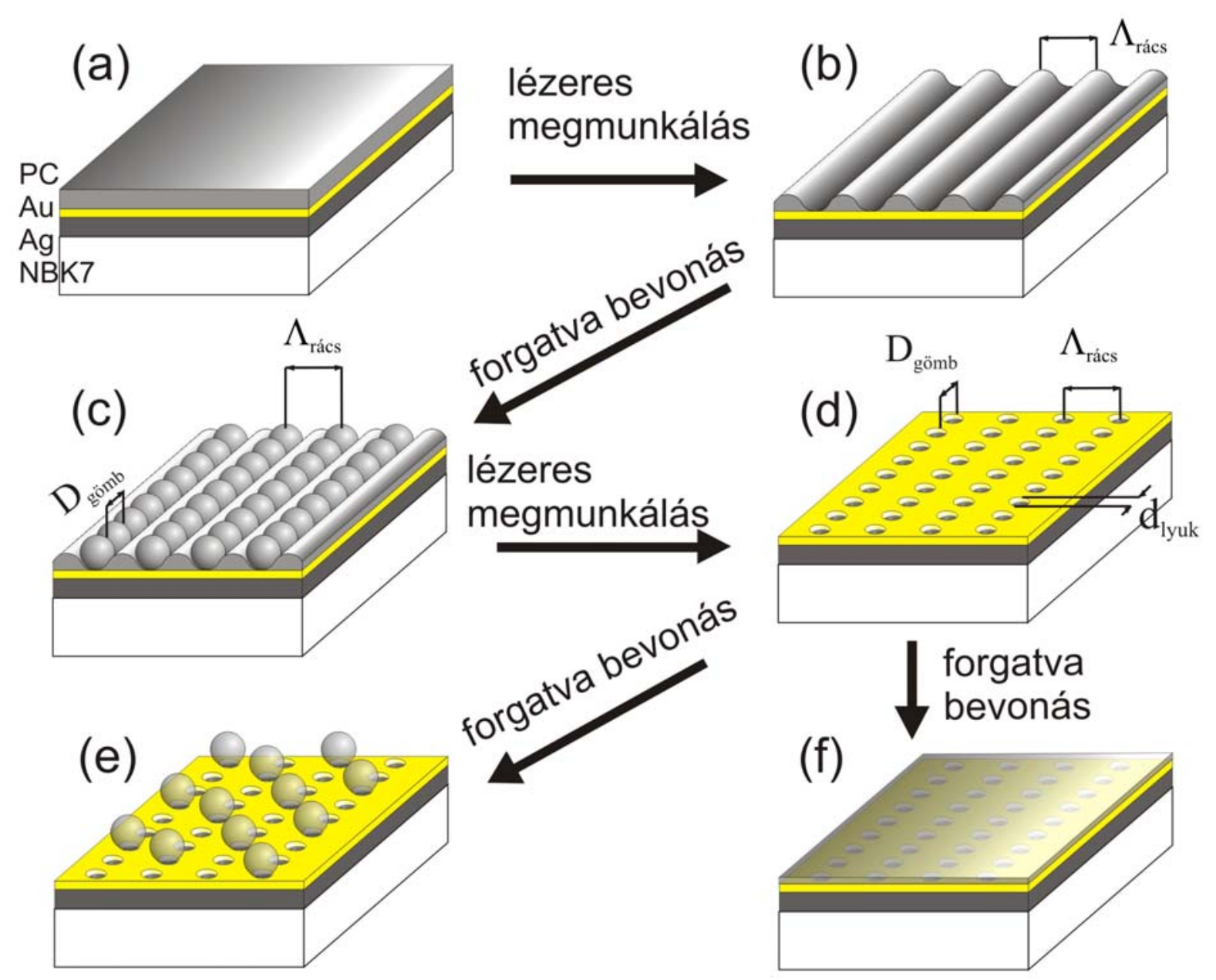

4. ábra. A mintakészítés lépései polimer rács előállításához (a, (b), majd kolloid litográfiás alkalmazáshoz (c-(f).

A fémfelületeket egyes esetekben polikarbonát réteggel (PC, polyoxycarbonyloxy-1,4phenylene-isopropylidene-1,4-phenylene, Bayer) is bevontuk. Ennek előnye, hogy a fémeknél alacsonyabb a roncsolási küszöbe, így rendezett és jól kontrollálható rácsok hozhatók létre a felületen kis energiasürüségeknél (4. (a), (b) ábra).

A polikarbonát réteget az ún. spin-coating, forgatva bevonás technikával vittük fel a felületre (4. (a), (f) ábra). A technika lényege, hogy a szilárd polikarbonátból kloroform oldószerrel megfelelő töménységü oldatot készítettünk, majd az oldatot a forgó mintafelületre cseppentve azon a folyadék szétterül és az oldószer gyors elpárolgása után vékonyréteg képezhető a felületen. A réteg vastagsága függ az oldat töménységétől és a minta forgatásának sebességétől, ez utóbbi jellemzően a 2000-2500 fordulat/perc tartományba esett.

Ugyancsak a forgatva bevonás technikáját használtuk kvarc kolloid gömböknek a rácsok felületére való felvitelénél (4.( c), (e) ábra). Ebben az esetben a $250 \mathrm{~nm}$ és $500 \mathrm{~nm}$ átmérőjű kvarc gömbök Millipore (MilliQ szürőberendezés) vizes kolloid oldatát cseppentettük a már megmunkált felületre, a forgatás pedig a rácsok völgyeibe rendezte a 
részecskéket [T4]. Itt a rács völgyeinek adhéziója és a felület periodikus topográfiája biztosítja a gömbök rendezettségét. A mintafelület közepére felvitt oldatmennyiség mindössze 2-4 $\mu \mathrm{l}$ volt a bevonni kívánt felület nagyságától függően, a forgatás pedig 1000-1500 fordulat/perc sebességgel történt.

A rács völgyeibe felvitt gömbök alkotta komplex maszkot $\mathrm{KrF}$ excimer lézerrel világítottam ki $F_{\text {litográfia }}=100-150 \mathrm{~mJ} / \mathrm{cm}^{2}$ energiasürüséggel (4. (d) ábra), majd a létrehozott lyukmintázatot vizsgálata után további kolloid gömbökkel vagy polikarbonát réteggel vontam vissza a már említett módszerek szerint (4. (e), (f) ábra, [T4]).

\subsection{Kolloidgömb litográfia}

Kolloidgömb litográfia (KGL, colloid sphere lithography, CSL) esetében a modellezés során Stöber-kvarc és fém kolloidgömböket használtam, a kísérleteket Stöber-kvarc gömbökkel végeztem el. A kvarc gömbök szintézisét az irodalomban leírt módszer szerint végeztük [70]. A gömbelőállítás során a felhasznált anyagok (Millipore víz, ammónia, etanol, tetraetil-ortoszilikát) megfelelő arányának beállításával befolyásolható a létrejövő, jó monodiszperzitással rendelkező kolloid oldatban lévő részecskék mérete [71]. A kísérletek során $250 \mathrm{~nm}$ és $500 \mathrm{~nm}$ átmérőjü kvarc kolloid részecskéket alkalmaztunk (4. (c), (e) ábra).

A kvarc kolloid gömbök felületre való felviteléhez két módszert használtam: az egyik a fent említett forgatva-bevonás módszere, a másik pedig a homogén monorétegek előállításra alkalmas Langmuir-Blodgett filmkészítési technika (5. ábra, [72]).

(a)

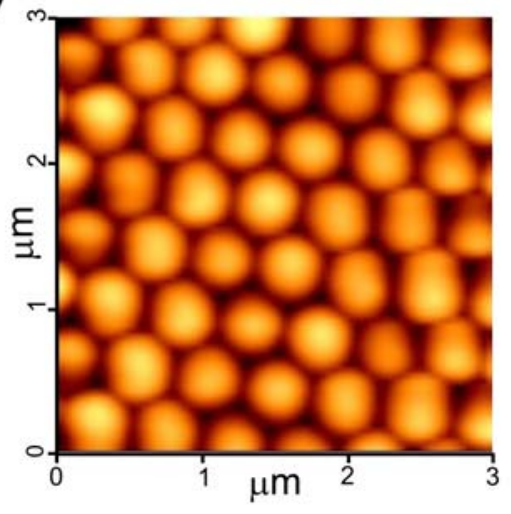

(b)

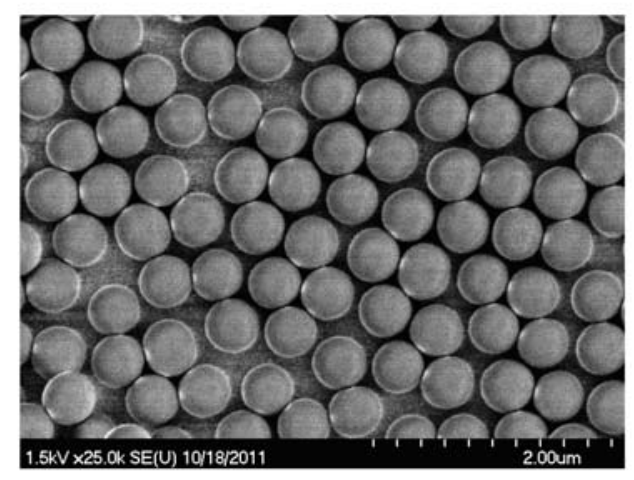

5. ábra. 500 nm-es Stöber kvarc kolloid gömb monoréteg (a) AFM és (b) SEM képe

A Langmuir-Blodgett technika alkalmazása során a felületre felvinni kívánt anyagot olyan folyadék felszínére helyezik, amelyen a felületi feszültség hatására monoréteget alkot. A folyadékot tartalmazó kádba hordozót merítve és azt a monoréteg kialakulása után lassan kiemelve a monoréteg átvihető a felületre. A mi esetünkben a kádba Millipore víz volt a 
felületet adó közeg, majd néhány 10 mikroliter Stöber-kvarc kolloid oldatot cseppentettem a felszínre. A monoréteg kialakulásához mintegy 12-16 órán keresztül nyugalomban hagytuk a lefedett elrendezést, majd az oldalnyomás állandó értéken való tartása mellett a részben vízbe merített üveg vagy üvegen fém-bevonatot tartalmazó hordozót lassan kiemeltem. Így mindkét gömbméret esetén viszonylag jó minőségű kolloid gömb monoréteget sikerült előállítani a mintafelületen (5. ábra).

\subsection{A felületek plazmon rezonancia spektroszkópiai jellemzése}

Az üveg (pl. NBK7) és ezüst fél-végtelen közegek határfelületén gerjeszthető plazmon hullámvektora a határoló fém és dielektrikum optikai tulajdonságainak függvénye:

$$
K_{\text {plazmon_üveg }}=\frac{2 \cdot \pi}{\lambda} \sqrt{\frac{\varepsilon_{\text {ivveg }} \cdot \varepsilon_{A g}}{\varepsilon_{\text {iveg }}+\varepsilon_{A g}}} .
$$

A sík fém-dielektrikum rétegen, a levegő oldali határfelületen gerjeszthető elemi plazmonhullámszámát a $\varphi_{\text {elemi }}$ plazmon rezonancia-szög ismeretében lehet kiszámolni:

$$
K_{\text {plasmon_levego }}=K_{\text {fotonikus }} \cdot \sin \varphi_{\text {elemi }}
$$

ahol

$$
K_{\text {fotonikus }}=\frac{2 \cdot \pi}{\lambda} \cdot n_{\text {üveg }},
$$

Rácsok jelenlétében plazmoncsatolás történhet megfelelő azimutális orientációban [52]. Az n-ed rendủ csatoláshoz szükséges azimutális orientáció (6.(a) ábra):

$$
\sin \gamma_{\text {csatolas }}^{n}=n \cdot K_{\text {rács }} / 2 K_{\text {plazmon }}
$$

ahol a rácsvektor

$$
K_{\text {rács }}=2 \pi / \Lambda_{\text {rács }} .
$$

A plazmoncsatolás eredményeként megjelenő felületi EM-módus hullámvektora:

$$
K_{\text {csatolt plazmon }}^{n}=K_{\text {plazmon }} \cos \gamma_{\text {csatolás }}^{n} \text {. }
$$


(a)

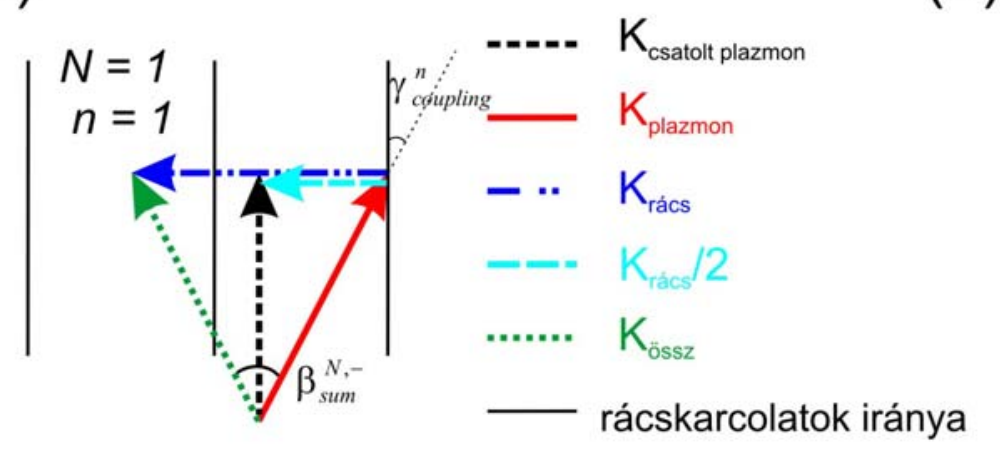

(b)

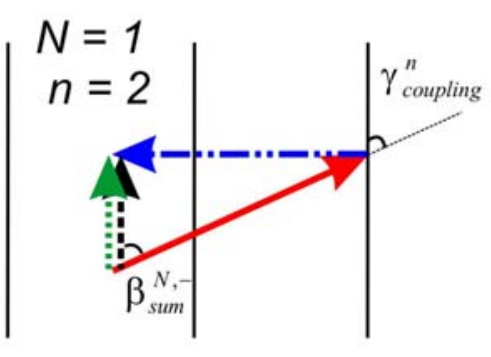

6. ábra. A plazmon rács-csatolásának elve.

A jó hatásfokú csatoláshoz szükséges minimális modulációs amplitúdó is meghatározható $[40,52]$ :

$$
a_{\text {csatolas }}^{n}=\frac{1}{\sin ^{2} \gamma_{\text {csatolas }}^{n}} \frac{\sin \varphi_{\text {elemi }}-\sin \varphi_{\text {csatolas }}^{n}}{\sin ^{2} \varphi_{\text {elemi }}} \cdot \frac{\sqrt{\varepsilon_{1}^{\text {felsö_fém }}}}{4 K_{\text {fotonikus }}} .
$$

A rácson ugyanakkor történhet plazmon szórás elöre/hátra (6.(b) ábra):

$$
K_{\text {szárt }}^{N, \pm}=\sqrt{K_{\text {plazmon }}^{2}+N^{2} K_{\text {rács }}^{2} \pm N \cdot 2 \cdot K_{\text {plazmon }} \cdot K_{\text {rács }} \cdot \sin \gamma},
$$

ahol a szórt plazmon terjedési iránya az alábbi módon számítható:

$$
\sin \beta_{s z o r t}^{N, \pm}=\frac{K_{\text {rács }} \cos \gamma}{K_{\text {szort }}^{N, \pm}}
$$

Az előre és hátraszórásból származó minimumhelyek:

$$
\varphi_{\text {szórt }}^{N, \pm}=\arcsin \frac{K_{\text {szart }}^{N, \pm} \cdot \lambda}{2 \cdot \pi \cdot n_{\text {üveg }}} .
$$

A létrehozott rétegkombinációk és megmunkált mintafelületek gyengített teljes visszaverődés (ATR) módszerén alapuló SPRS vizsgálatára a hagyományos Kretschmann-féle elrendezés egy módosított változatát építettük meg (7. ábra, [52]). Esetünkben a fémréteg nem a fényt becsatoló prizmára volt párologtatva, hanem külön, a lencsével megegyező anyagú üveghordozóval dolgoztunk. A becsatolás nem prizmán keresztül, hanem az üveghordozóval együtt teljes félhengerré kiegészített lencsével történik, így ez a konfiguráció a szögfüggés müszakilag könnyebben megvalósítható vizsgálatát teszi lehetővé. A lencse-hordozó rendszer forgástengelye a vizsgálandó felület síkjába esik, így a forgatás ellenére biztosított, hogy mindig ugyanazt a felületrészt világítjuk meg. Az elrendezés fényforrása egy folytonos 
üzemmódú Nd-YAG lézer (Intelite, GSLN32-20), ennek 2 mW-os nyalábjával világítunk ki egy félhenger-lencsét (Geodasy), a nyaláb párhuzamosítását végző teleszkópot alkotó két hengerlencsével valósítottuk meg. Az NBK7-es üvegből készített mintákat a lencsékkel megegyező törésmutatójú immerziós folyadék (Zeiss, Immersol 518F) segítségével rögzítjük a fél-hengerlencséhez. Az optikai elemek és a detektor szinkronizált, precíziós forgatása kétkörös goniométerrel (OWIS, DMT 65) történik, amellyel a szögelfordulás $0.08^{\circ}$-os léptékben változtatható. A szögfüggő visszavert fényt egy szilícium fotodiódával detektáljuk (Thorlabs, DET210).

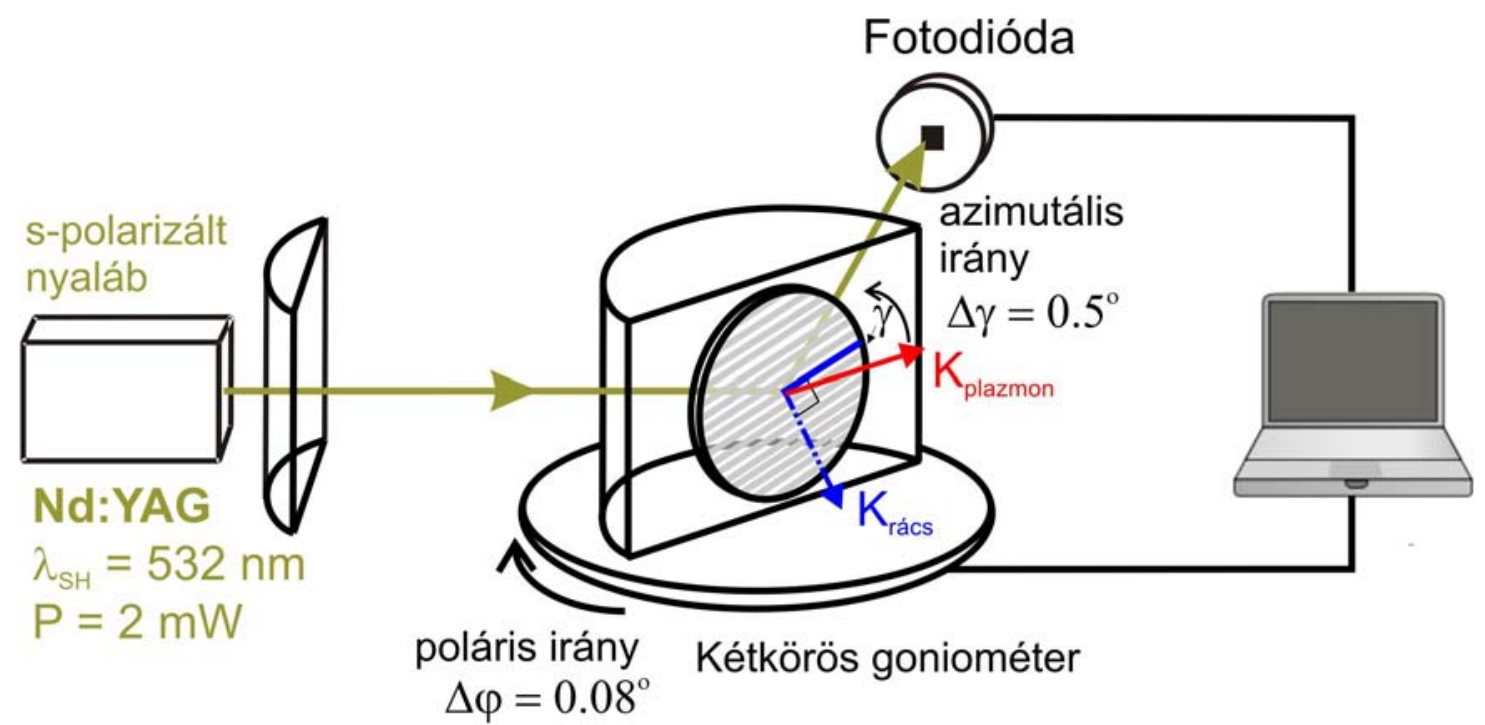

7. ábra. A módosított Kretschmann-féle mérési elrendezés vázlata

\subsection{Atomi erő mikroszkópiai vizsgálat}

A rétegek felületi topográfiájának vizsgálatára az atomi erő mikroszkópia (AFM) módszerét alkalmaztam [73]. A modern atomi erő mikroszkópok felbontása jóval a diffrakciós határ alatti, a nanométer töredékének nagyságrendjébe esik, így a minták olyan részletes tanulmányozását teszi lehetővé, amit más vizsgálatokkal nem vagy csak részben valósíthattam volna meg.

Az AFM alapja egy mikrométeres mérettartományba eső, jellemzően szilícium alapú és egyes esetekben a mérést elősegítő dielektrikum, fémes vagy mágneses bevonattal ellátott tütartó rugó (angol nyelvű szakirodalomban cantilever) és az azon lévő tủ adja. A tủ hegyének görbületi sugara jellemzően a néhány 10 nanométeres tartományba esik, de az ún. supertip-ek akár $\sim 1 \mathrm{~nm}$-es görbületi sugarúak is lehetnek. A tü és tütartó pontos mozgatását a müszerekben piezoelektromos elemekkel valósítják meg. 
A mérés folyamata a következőképpen történik: a tüt a felülethez közelítve a tü és a minta közt fellépő erők - melyek lehetnek mechanikai, elektromágneses, van der Waals, kémiai kölcsönhatásból származók - elhajlítják a mindössze néhány tized N/m-től néhány $\mathrm{N} / \mathrm{m}$-ig terjedő rugóállandójú tủtartót. A tủ és a minta közötti távolság vagy erő állandósága a visszacsatoló rendszer használatával érhető el, ez pontosan megvalósítható úgy, hogy a tütartó hátsó felületéről egy négyszegmensü fotodiódára verődő lézernyaláb pozícióját aktívan központosítja a rendszer (8. ábra.).

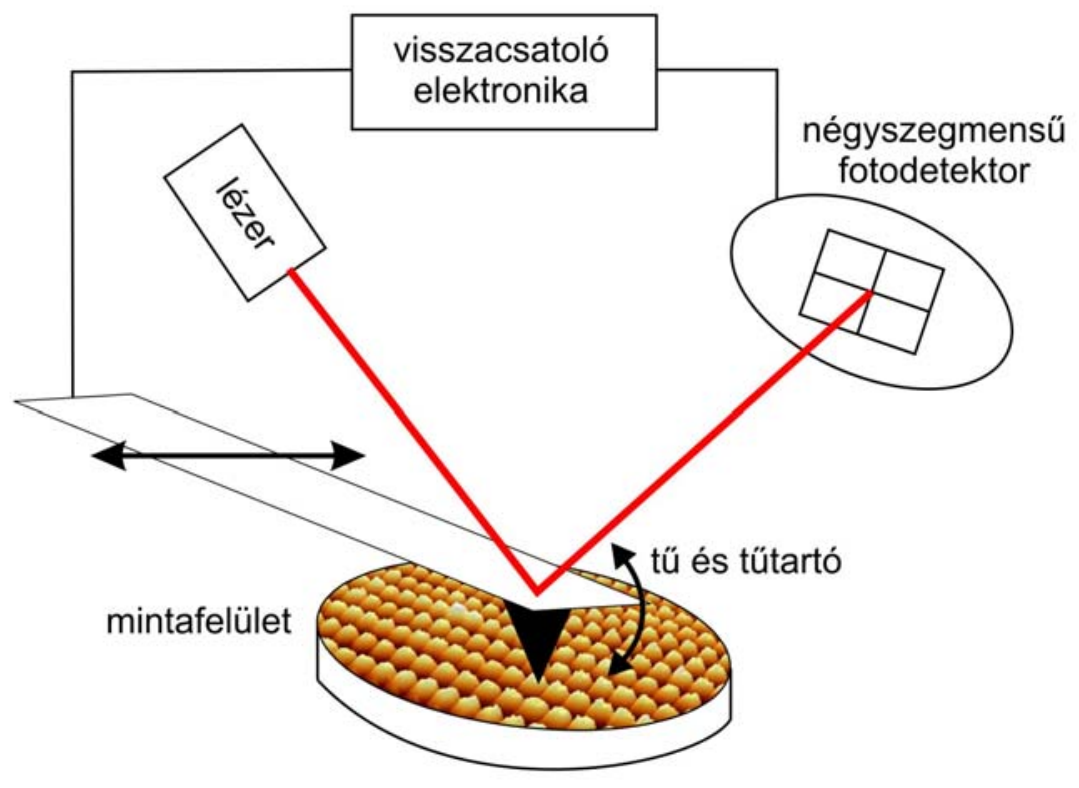

8. ábra. Az atomi erő mikroszkóp működési elve.

Méréseim során a dinamikus ún. tapping üzemmódot használtam, melynek során a tü statikus kontakt móddal szemben nem érintkezik közvetlenül a felülettel, így kényesebb, sérülékenyebb, akár élő biológiai mintafelületek is mérhetők ezzel a módszerrel. Ebben az esetben a tü a felülethez közel jellemezően 100-200 nm amplitúdójú rezgést végez, a saját rezonancia-frekvenciájának közelében, ez tütípustól függően $100 \mathrm{KHz}$-es nagyságrendü. A tü és a felület között fellépő erők hatására a rezgés amplitúdója csökken. A visszacsatoló elektronika az amplitúdó állandó értéken tartása érdekében a tü-mintafelület távolságát a $z$ piezoelektromos elemre kiadott feszültséggel folyamatosan szabályozza, miközben a felületet az $x$ és y tengelyek mentén pásztázza. A piezo-feszültséggel arányos jel adja meg a topográfiai magasságot egy adott pontban, mely koordinátát az $x-y$ mozgatást végző elemek feszültségéből számolja vissza az elektronika, így egy háromdimenziós képet ad az adott felszínről. 
A fáziskép segítségével a felületen elhelyezkedő különböző anyagokat lehet feltérképezni az oszcilláció fázisának a vezérlő jelzéshez képest mért változásából, mivel a fázis eltolódás többek között érzékenyen változik a töltéseloszlás által meghatározott elektrosztatikus tulajdonságaitól, a felület összetételétől, adhéziójától, viszko-elasztikus tulajdonságaitól függően [74, 75].

Az eredmények fejezetben bemutatott topográfia és fázis képeket egy XE-100 típusú (PSIA, Park Systems) készülékkel végeztem [T1-T4].

\subsection{Pásztázó elektronmikroszkópos vizsgálat}

Az elektronmikroszkóp elektromágneses lencsékkel (nyalábeltérítő tekercsekkel) kondenzált elektronnyaláb segítségével ad képet egy tárgyról, a kis hullámhossz nagy felbontást tesz lehetővé [76-78]. A pásztázó elektronmikroszkópban az elektronnyaláb rasztermozgatással vizsgálja a felületet.

A képek egy hideg téremissziós elektronmikroszkóppal (Hitachi S-4700) készültek. Az ilyen típusú mikroszkópok elektronforrása jellemzően wolfram anyagú elvékonyított hengerek, ezeknek kis görbületű sugarú csúcsából az alkalmazott nagyfeszültség hatására a csúcshatás miatt megjelenő erős elektrosztatikus tér miatt lépnek ki az elektronok. A kilépő elektronokat az elektromos tér gyorsítja (ez esetben $0,5-30 \mathrm{kV}$ 0,1 kV lépésközzel), az elektromágneses lencsék pedig fókuszálják. A készülék másodlagos elektronok detektálásán alapuló (Secondary Electron Imaging, SEI) üzemmódját használtuk. Ez az üzemmód a pásztázó elektronnyaláb és a mintafelület közti kölcsönhatás során szóródik, és további elektronokat távolít el, ezek a másodlagos elektronok használhatóak képalkotásra. A másodlagos elektronok a minta felső vékony rétegéből lépnek ki, így a kapott kép erről ad információt.

A pásztázó elektronmikroszkóp előnye az AFM-el szemben, hogy jóval nagyobb, akár milliméteres nagyságú mintákat is lehet vizsgálni az AFM néhány 10 mikronos tartományával szemben, és egy felvétel elkészítése is gyorsabb. Hátránya, hogy 3D topográfiai kép nem készíthető ezzel, valamint a müködéshez elengedhetetlen vákuumkörnyezet nem teszi lehetővé biológiai vagy egyéb párolgó anyagok vizsgálatát. További hátrány lehet, hogy a nem vezető mintafelületet vezető (legtöbb esetben nemesfém) réteggel kell bevonni, ez egyes esetekben sértheti a minta felszínét, előfordulhat, hogy a bevonás nem is lehetséges. 


\subsection{Biológiai anyagok felvitele}

A készített mintákat biológiai anyagok detektálására használtuk, vizsgáltuk a sztreptavidin kis mennyiségű kimutatását különböző esetekben. A peptideket (lgiir-NH2 és biotinilált lgiir-NH2) első szintetizálás után felhasználásig liofilizált formában $-20^{\circ} \mathrm{C}$ fokon tároltuk. A felhasználandó peptid-mennyiséget steril desztillált vízben oldottuk fel, koncentrációjuk $2 \mathrm{mg} / \mathrm{ml}$ volt. Az oldatok elkészítéséhez jelölés nélküli (Szt) és $d_{C G}=10 \mathrm{~nm}$ kolloid arany részecskékkel jelölt sztreptavidin (CG-Szt, S 9059, Sigma-Aldrich) valamint $d_{F N G}=1.4 \mathrm{~nm}$ átméröjü arany részecskéket tartalmazó FluoroNanoGold Sztreptavidin (FNG Szt, 7016, Nanoprobes Inc.) molekulákat használtunk. A mintákra való anyagfelvitel minden esetben frissen készült oldatok használatával végeztük. A sztreptavidin és biotin között az egyik legerősebb nem kovalens kötés jön létre, így a biotin mennyiségének szabályozásával a felülethez kötött sztreptavidin mennyisége, és így a jelölő aranymennyiség állandósága jól befolyásolható, ami a jelöletlen és az egyes jelölt fehérjék adta mérések összehasonlításához elengedhetetlen.

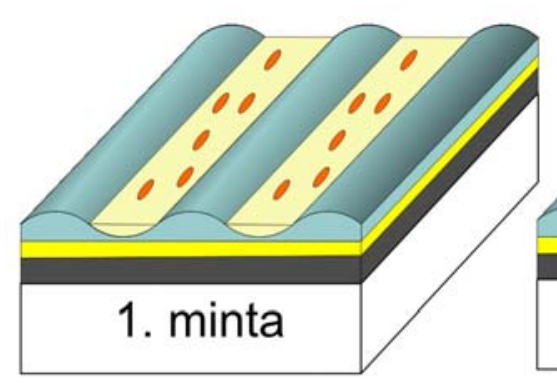

$\mathrm{d}_{\mathrm{Ag}}=38 \mathrm{~nm}$
$\mathrm{~d}_{\mathrm{Au}}=7 \mathrm{~nm}$
$\mathrm{~d}_{\mathrm{PC}} \approx 35 \mathrm{~nm}$
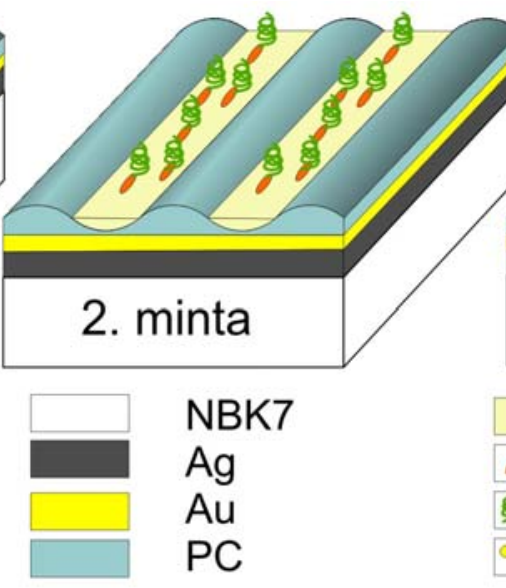

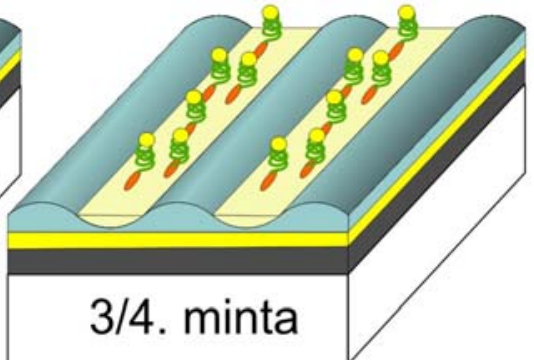

peptid

biotin

sztreptavidin

arany jelölés

9. ábra. A szelektív bio-molekula kikötés elve és lépései.

A mintákat fehérjefelvitel előtt desztillált vízzel öblítve készítettük elő, majd lgiir-NH2 peptid és biotinilált lgiir-NH2 peptid 20 illetve $25 \mu \mathrm{g} / \mathrm{ml}$ koncentrációjú foszfát pufferes oldatába (PBS, $137 \mathrm{mM} \mathrm{NaCl}, 2,7 \mathrm{mM} \mathrm{KCl}, 8 \mathrm{mM} \mathrm{Na} 2 \mathrm{HPO} 4,1,5 \mathrm{mM} \mathrm{KH} \mathrm{KO}_{4}$; $7,4 \mathrm{pH})$ merítettük. A PBS oldatban található foszfátok az állandó $\mathrm{pH}$ értéket biztosítják, az ionkoncentráció pedig az élő szervezeteknek megfelelő. A bemerítéses eljárás célja, hogy az erősen adhezív völgyeket teljesen kitöltse a kis molekulájú peptid, ugyanakkor ebben a bevonatban pedig biztosítsuk a sztreptavidint kikötő kis mennyiségű biotin molekulák egyenletes eloszlását (9. ábra). Tiszta PBS oldattal való háromszori mosás után második lépésben a 2-es számú mintára jelöletlen $\mathrm{c}_{\mathrm{St}}=4 \mathrm{mg} / \mathrm{ml}$ sztreptavidint tartalmazó, a 3-as illetve 
4-es mintára pedig a kolloid arannyal jelölt illetve FNG sztreptavidint vittük fel ugyanolyan koncentrációban inkubálással. A peptiddel bevont minták inkubálási ideje 1 óra, a sztreptavidin felvitele 30 perc volt $37^{\circ} \mathrm{C}$ hőmérsékleten, vízszintes rázatón való mozgatással. Rázatás után desztillált vízzel való háromszori mosás után egy napig szobahőmérsékleten szárítottuk [T3]. 


\section{Elméleti módszerek}

\subsection{Végeselem módszeren alapuló modellezés}

A végeselem módszer (Finite Element Method, FEM) egy numerikus számítási eljárás, mellyel meghatározott parciális differenciálegyenletek közelítő megoldásait lehet kiszámolni egy jól definiált térháló csomópontjaiban, amely megoldás a metszéspontok közötti térre extrapolálható. A FEM módszer változatos fizikai problémák modellezésére alkalmazható a hőterjedéstől kezdve a nyíróerők tanulmányozásán át olajipari csővezetékek szimulálásáig, mindössze az adott alkalmazásnak megfelelő fizikai folyamatok megfelelő matematikai leírása szükséges. Fontos a differenciálegyenletek és számítási megoldási módok megválasztása oly módon, hogy a kapott megoldás numerikusan kezelhető legyen (a számítási erőforrás kapacitásokat megfelelően használja ki) és a megoldás megfelelően extrapolálja a valóságot. Az egyes módszerek és közelítések egyszerübb modellekkel jól tesztelhetőek, a megoldás pontossága és esetleges korlátai jól meghatározhatóak. A módszer matematikája gyakran jól ismert, ezért akár önálló programozással is felállítható egy rendszer, de több, tudományos és ipari alkalmazásoknál használt, már bizonyított kereskedelmi program(csomag) létezik, melyekkel jelentős idő- és energia-megtakarítás érhető el.

A nanofotonikában és nanoplazmonikában a Maxwell-egyenletek numerikus megoldása a cél, ezt valósítottuk meg a Comsol Multiphysics programcsomag (Comsol AB) rádiófrekvenciás $(\mathrm{RF})$ moduljának segítségével (10. ábra).

(a)

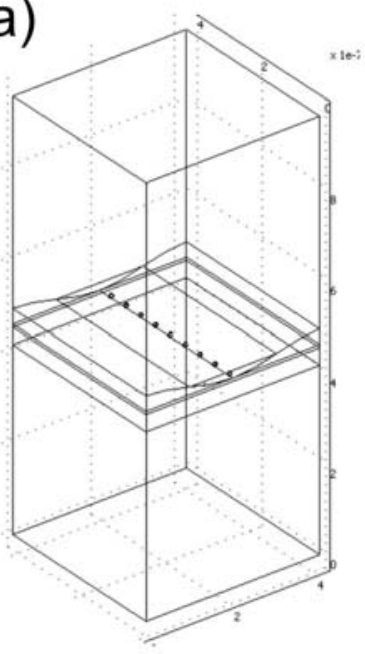

(b)

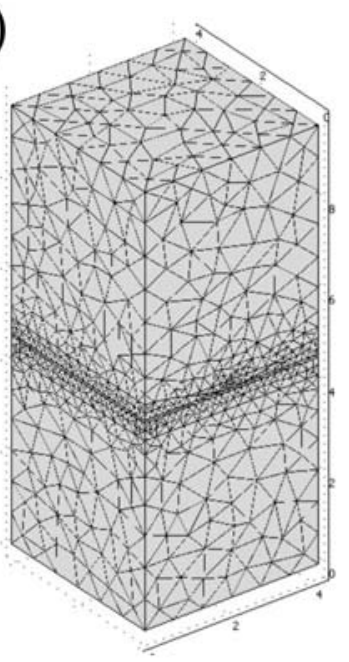

(c)

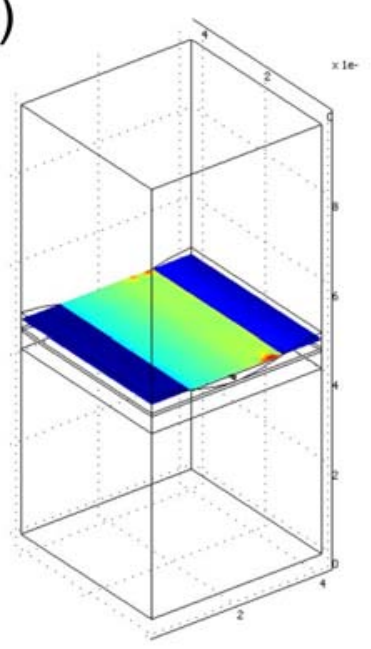

10. ábra. Végeselem modell geometria, térháló és a megoldás egy adott metszetben. 
A modell rendszereket minden esetben síkhullámokkal világítottuk ki, ezek s- vagy ppolarizáltak voltak, tranzverz elektromos (TE) vagy tranzverz mágneses (TM) hullámként definiálva. Az SPR méréshez hasonlóan definiált kivilágítás szögeit a 11. ábra szemlélteti. Általános esetben a felület geometriai tengelyeihez képest határoztuk meg a $\varphi$ poláris és $\gamma$ azimuthális szöget, ezeket megfelelő lépésekben változtatva a teljes modellt a bemenő paraméterkészlet minden kombinációjára lefuttatva egy háromdimenziós szögfüggő térkép határozható meg egy adott fizikai mennyiségről, pl. a normalizált elektromos mezőről.

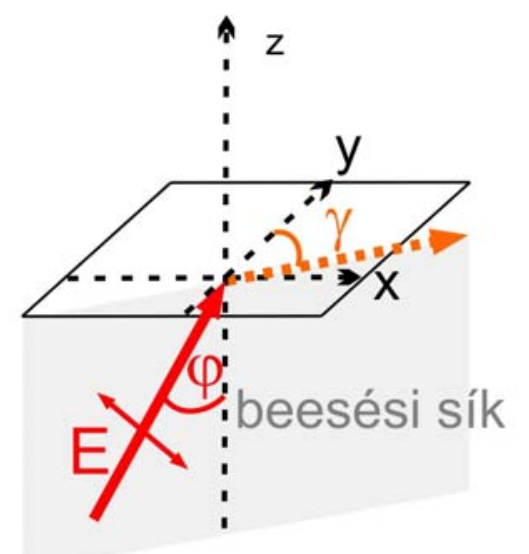

11. ábra. Végeselem modell kivilágítása.

A síkhullámok terjedését az egyes esetekben az alábbi összefüggésekkel írtuk le, ahol az $\mathbf{E}$ és a $\mathbf{H}$ mágneses tér komponensei:

$$
\begin{aligned}
& E_{x} \cdot \exp \left\{-j\left[\left(k_{x} \cdot x\right)+\left(k_{y} \cdot y\right)+\left(k_{z} \cdot z\right)\right]\right\}, H_{x} \cdot \exp \left\{-j\left[\left(k_{x} \cdot x\right)+\left(k_{y} \cdot y\right)+\left(k_{z} \cdot z\right)\right]\right\}, \\
& E_{y} \cdot \exp \left\{-j\left[\left(k_{x} \cdot x\right)+\left(k_{y} \cdot y\right)+\left(k_{z} \cdot z\right)\right]\right\}, H_{y} \cdot \exp \left\{-j\left[\left(k_{x} \cdot x\right)+\left(k_{y} \cdot y\right)+\left(k_{z} \cdot z\right)\right]\right\}, \\
& E_{z} \cdot \exp \left\{-j\left[\left(k_{x} \cdot x\right)+\left(k_{y} \cdot y\right)+\left(k_{z} \cdot z\right)\right]\right\} H_{z} \cdot \exp \left\{-j\left[\left(k_{x} \cdot x\right)+\left(k_{y} \cdot y\right)+\left(k_{z} \cdot z\right)\right]\right\},
\end{aligned}
$$

Az TM és TE polarizációnak megfelelő esetekben ezek az összefüggések egyszerűsödnek, így az elektromos és mágneses tér komponensei TM polarizációra:

$$
\begin{gathered}
E_{x}=-E_{0} \cdot \cos \varphi \cdot \sin \gamma, H_{x}=H_{0} \cdot \cos \gamma, \\
E_{y}=-E_{0} \cdot \cos \varphi \cdot \cos \gamma, H_{x}=-H_{0} \cdot \sin \gamma, \\
E_{z}=E_{0} \cdot \sin \varphi, H_{z}=0 ;
\end{gathered}
$$

A TE polarizáció esetén az EM tér komponensei:

$$
\begin{gathered}
E_{x}=E_{0} \cdot \cos \gamma, H_{x}=H_{0} \cdot \cos \varphi \cdot \sin \gamma, \\
E_{x}=-E_{0} \cdot \sin \gamma, H_{y}=H_{0} \cdot \cos \varphi \cdot \cos \gamma, \\
E_{z}=0, H_{z}=-H_{0} \cdot \sin \varphi .
\end{gathered}
$$

A terjedést jellemző $\mathbf{k}$ hullámvektort minden esetben a következők definiálják:

$$
k_{x}=k_{0} \cdot \sin \varphi \cdot \sin \gamma
$$




$$
\begin{gathered}
k_{y}=k_{0} \cdot \sin \varphi \cdot \cos \gamma \\
k_{z}=k_{0} \cdot \cos \varphi
\end{gathered}
$$

Cirkuláris polarizáció esetén a fent leírt módszerrel határoztuk meg a belépő fény EM tér komponenseit, úgy, hogy $\pi / 2$ fáziskülönbséggel két lineárisan poláros nyalábot határozunk meg a belépési felületen, amelyek kezdeti beesési síkja egymásra merőleges.

Minden modell esetén a fenti leírás valamelyikét használtuk, az ún. port határfelületpáron határoztuk meg a bemenő nyaláb teljesítménysürüségét. Az egymással párhuzamos függőleges határfelületeken ún. periodikus határfeltételt alkalmaztunk (Floquet periodicitás), mellyel az oldalfalakon a fázishelyes csatolás biztosítható, így tulajdonképpen egyetlen egységcella vizsgálatával egy laterálisan végtelen optikai rendszer modellezését végeztük el. A modellbe beépített anyagok törésmutatóit (jellemzően dielektrikumok esetén) Cauchyformulákkal határoztuk meg az adott hullámhosszon, fémeknél pedig, ahol az abszorpció is lényeges szerepet játszik, a komplex dielektromos állandók valós és képzetes részeit irodalmi adatok alapján specifikáltuk [79].

Az új kolloid litográfiás eljárás modellezése során a kétnyaláb-interferencia periódusának megfelelő méretű modell megrajzolása elengedhetetlen volt, így volt biztosítható az interferencia mintázat és a kolloid gömb monoréteg megfelelő szinkronizálása. Ebben az esetben két, a felületek normálisához képest azonos nagyságú, de ellentétes előjelü beesési szögben érkező nyalábot definiáltunk, ezek kezdőfázisának hangolásával értük el, hogy az interferenciamaximumok pontosan a kolloid gömbök középpontjába essenek. A kivilágítás teljesítménysürüségét úgy határoztam meg, hogy a bemenő nyaláb térerőssége $1 \mathrm{~V} / \mathrm{m}$ legyen, így az elektromos térben elérhető erősítés könnyen számolható.

Nemcsak szögfüggő vizsgálatot végeztünk, hanem periodikus lyukmintázatokra a felület transzmissziójának hullámhosszra való érzékenységét is vizsgáltuk. Ebben az esetben az egyes anyagok optikai tulajdonságainak a hullámhosszfüggését is figyelembe vettük, dielektrikumok esetén a törésmutató értékét Cauchy-formula segítségével illesztettük, fémek dielektromos állandóinak komponenseit pedig az irodalmi adatok spline illesztéséből az adott hullámhossztartomány lépéseinek megfelelő kapott értékeket olvastuk be táblázatból.

Stöber-kvar kolloid gömbök modellezése során a nano-objektumok megnyúltságát jellemző $(b-a) / b$ ellipticitás paramétert a 25. (c) ábrán foglaltam össze. A kolloid gömbök alatt elérhető erösítést az elérhető térmaximum és a határfelületen beküldött elektromos térerösség hányadosával jellemzem (25. (d) ábra). 


\subsection{Szögfüggés vizsgálata analitikus számolással}

A mintafelületek tervezésére, modellezésére illetve az SPRS mérések során kapott rezonanciagörbék elemzésére, valamint a FEM modellezésből kapott eredmények ellenőrzésére analitikus számítási módszereket is alkalmaztunk.

Az analitikus számolásra a transzfer mátrix módszert (transfer matrix method, TMM) használtam [80], mellyel vékonyréteg és vékonyrétegek kombinációjának reflexiója, transzmissziója és abszorpciója egyszerủen számolható. A módszer lényege, hogy a rétegek határán egy megfelelő transzfer mátrix segítségével az elektromágneses tér reflexiója, transzmissziója pontosan számolható, több réteg esetén pedig a teljes rendszerre vonatkozó mátrix kiszámítható. A módszer használatával pl. nagyon jó minőségű magas reflexiós vagy antireflexiós tükrök készíthetőek megfelelően megválasztott törésmutatójú és vastagságú dielektrikum rétegek alkalmazásával. A TMM számítás folytonos rétegek viselkedésének jellemzésére alkalmas, ennek ellenére periodikusan modulált felületek esetén is segít megérteni a fizikai folyamatokat, melyek a más módszerrel számolt vagy mért SPRS görbék jellemző karakterisztikáját adják. 


\section{Eredmények}

\subsection{Plazmonikus struktúrák tervezése és előállítása}

Fémrácsok

A kísérletek első lépéseként megmunkálás előtt a hordozóra felvitt ezüst és arany vékonyréteg vastagságát határoztuk meg. A vékonyrétegek dielektromos állandói különböznek a tömbanyagok esetén mérhető értékeknél, így a számolások során az általánosan használt irodalmi értékeket vettük figyelembe (1. táblázat) [79].

\begin{tabular}{|l|l|l|}
\hline Réteg & $\varepsilon_{1}$ & $\varepsilon_{2}$ \\
\hline NBK7 & 2.307 & 0 \\
\hline Ezüst & -10.0534 & 0.33799 \\
\hline Arany & -5.10288 & 2.85921 \\
\hline
\end{tabular}

1. táblázat. A fémrácsokra vonatkozó számolások során használt dielektromos állandók a különböző anyagokra.

A Fresnel egyenleteken alapuló TMM számolásokat a mért görbékkel összehasonlítva megállapítottuk, hogy a bimetál rétegekben az arany és ezüst filmek átlagvastagsága a következőképpen alakult: az 1. fémes minta esetén $\mathrm{d}_{\mathrm{Ag}}=34.9 \mathrm{~nm}, \mathrm{~d}_{\mathrm{Au}}=14.8 \mathrm{~nm}$ ( 12. ábra), $\mathrm{d}_{\mathrm{Ag}}=41.3 \mathrm{~nm}$ és $\mathrm{d}_{\mathrm{Au}}=9.5 \mathrm{~nm}$ a 2. fémes mintán (12. ábra), a 3. fémes mintán pedig $\mathrm{d}_{\mathrm{Ag}}=45.3 \mathrm{~nm}$ és $\mathrm{d}_{\mathrm{Au}}=6.3 \mathrm{~nm}$ értékeket kaptam.

Az ideális megmunkálási paraméterek meghatározása több lépcsőben történt. Alacsonyabb, $\quad F_{a t l}=20-33.5 \mathrm{~J} / \mathrm{cm}^{2}$ átlagos energiasürüségü lézernyalábbal, néhány impulzussal kivilágítva a felületet mindössze néhány nanométer modulációs mélységű rács jellegű struktúrát sikerült előállítani $P_{\text {rács }}=900 \mathrm{~nm}$ periódussal. Az ideális lézeres besugárzási paraméterek elérése elengedhetetlen a megfelelő modulációs mélység eléréséhez. Kísérleteink során amikor az interferencia vizibilitása közelítette az ideális értéket, az interferenciamaximumokban elérhető kétszerezett intenzitás többszörös kivilágítás esetén folyamatos anyagváltozást eredményezett, így a nagyobb lövésszámmal és kisebb energiasürüséggel is rácsot tudtunk előállítani. A rács modulációs mélysége az alkalmazott lövésszámmal növekedett $\mathrm{N}=100$-200 lövésig, ennél nagyobb értékeknél azonban a mechanikai rezgések miatt a felületi struktúra elmosódottá, rendezetlenné vált.

Nagyobb energiasűrűséggel, de az $N=100$ lövésszámot állandó értéken tartva nemcsak a rácsok mélysége növekedett, de azok rendezettsége is javult. $F_{a} t l=39.5 \mathrm{~J} / \mathrm{cm}^{2}$ energiasűrüség alkalmazása esetén a rács modulációs mélysége összemérhető a megmunkált 
fémrétegek összvastagságával, $F_{a}$ atl $=41.6 \mathrm{~J} / \mathrm{cm}^{2}$ értéknél nagyobb energiasürüség alkalmazása esetén pedig már a hordozó felülete is sérült.
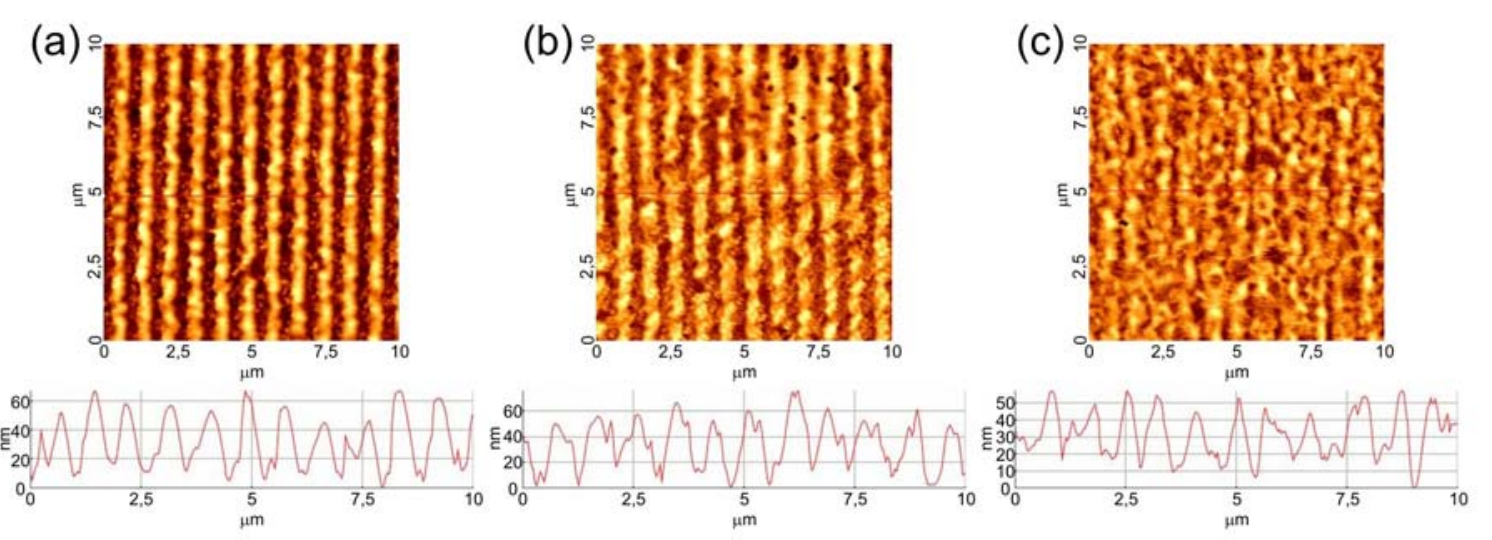

12. ábra. 1-es, 2-es, 3-as fémfilmeken készített rácsok AFM topográfiája.

Az egyes mintákon található különböző rétegvastagság-párok összehasonlítását a fent leírtak alapján ideálisnak tekinthető, $F_{a} t l=39.5 \mathrm{~J} / \mathrm{cm}^{2}$ energiasűrüség és $N=100$ lövésszám alkalmazásával végeztük. A készített AFM képek (12. ábra) összehasonlításából megállapítható, hogy azonos körülmények mellet a vastagabb aranyréteggel bevont minta rendezettebb és nagyobb modulációs mélységű rácsokat eredményezett. Az 1-es fémes mintán $a_{\text {fémrács } 1}=20-25 \mathrm{~nm}$ modulációs mélységü, szorosan elhelyezkedő cseppszerü részecskékből álló rács topográfiáját mutatja az AFM mérés (12. (a) ábra) Valamivel rendezetlenebb struktúrát mutat a 2-es fémes mintán végrehajtott AFM mérés, a kevésbé négyszög jellegü vonalmetszet átlagosan $a_{\text {fémrács } 2}=20-25 \mathrm{~nm}$-es modulációs mélységet mutat (12. (b) ábra). Részben rendezetlen periodikus struktúra figyelhető meg a 3-as fémes mintán, az előzőeknél valamivel kisebb, $a_{\text {fémrács } 3}=20-25$ nm-es modulációs mélységgel (12. (c) ábra). A fém rácsok nanométeres tartományba eső szemcsékből és lyukakból állnak, ezek mennyisége, rendezettsége és mérete a film összetételétől és az alkalmazott lézerkezelés paramétereitől függ [T1].

\section{Polimer rácsok}

Polimer rácsok megmunkálására a mesterrácson alapuló elrendezést választottuk. Három különböző struktúrát hoztunk létre a felületen, mindegyik esetben $416 \mathrm{~nm}$ periódussal, melyek az alkalmazott mesterrács rácsállandója határozott meg. Az első esetben az spolarizált fénnyel kivilágítva a felületet a kétnyaláb interferencia és a szórt nyaláb interferencia párhozamos, így a felületen vonalas rácsot hoztunk létre, melyet a hullámhossznál kisebb méretü LIPPS kialakulása némileg modulál (13.(a) ábra). A második esetben p-polarizált fényt alkalmaztunk, ekkor a kétnyaláb és a szórt nyaláb interferencia adta 
periodikus mintázat egymásra meröleges, ennek következtében a rácsvonulatok mentén rendezett szorosan elhelyezkedő cseppszerü képződmények jönnek létre, az így létrehozott felületet cseppes rácsnak neveztük el (13.(b) ábra). A harmadik elrendezésben ismét s-polarizált nyalábot használtunk, de két megmunkálás között a mintát $60^{\circ}$-al elfordítottuk, miközben a megmunkált területrész ugyanaz maradt. Ezzel az eljárással egymást keresztező rácsok rombuszszerü alakzatokból álló mintázatát sikerült előállítani (13. (c) ábra). A lézer paramétereinek egyszerü változtatásával három különböző felületi morfológiát sikerült elöállítani [T2].

(a) Vonal_1rács

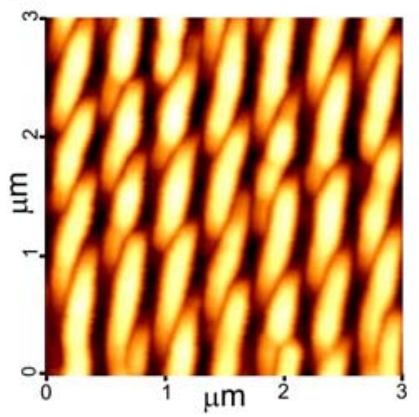

$10.47 \mathrm{~mJ} / \mathrm{cm}^{2}, 90 \mathrm{sec}$ (b) Cseppes_1 rács

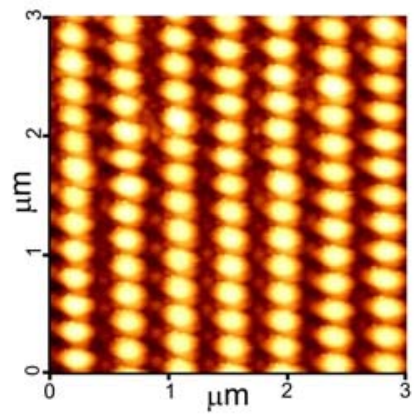

$10.47 \mathrm{~mJ} / \mathrm{cm}^{2}, 90 \mathrm{sec}$ (c) Kereszt_1 rács

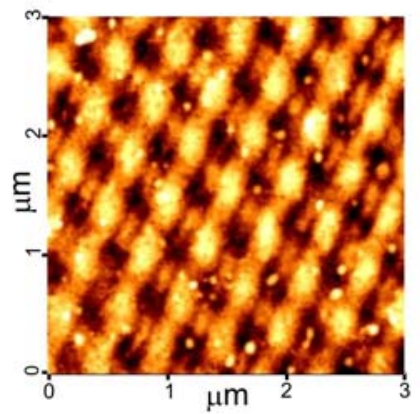

$10.47 \mathrm{~mJ} / \mathrm{cm}^{2}, 2 * 90 \mathrm{sec}$

13. ábra. Polimer rácsok topográfiája (a) vonalrács, (b) cseppes rács, (c) keresztrács.

Kolloid gömbök polimer sablonrácson: kompozit-maszk

A mintakészítési eljárásnál már említett eljárással, forgatva bevonással $250 \mathrm{~nm}$ és $500 \mathrm{~nm}$ átmérőjü kvarc kolloid gömböket vittünk fel $416 \mathrm{~nm}$ és $833 \mathrm{~nm}$ periódusú, mesterrácsot alkalmazó módszerrel előállított rácsokra (4.(c) ábra).

(a)

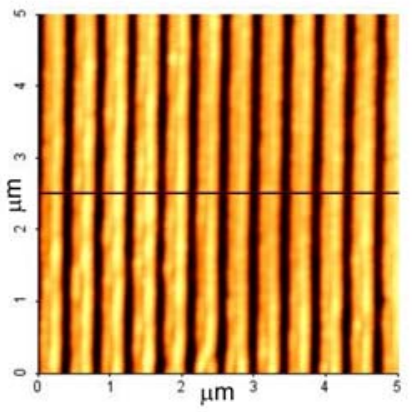

$$
\Lambda_{\text {rács }}^{1}=416 \mathrm{~nm}
$$$$
\Lambda_{\text {rács }}^{2}=833 \mathrm{~nm}
$$

(b)

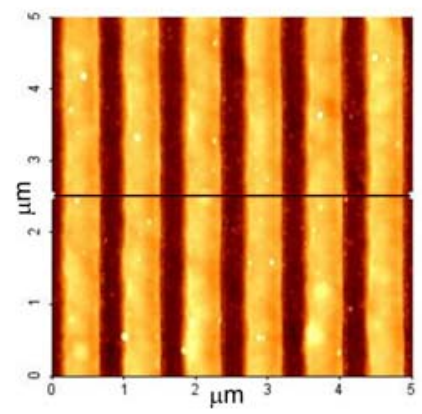

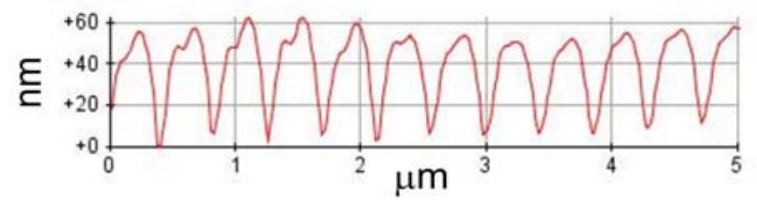

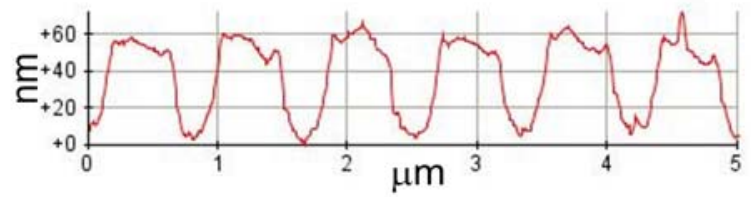

14. ábra. (a) $416 \mathrm{~nm}$ és (b) $833 \mathrm{~nm}$ periódusú maszkként alkalmazott rács 
A megfelelő modulációs mélységű polikarbonátba írt rácsok eléréséhez ez esetben az interferencia litográfiához $\quad \mathrm{F}_{\mathrm{IL}}=12.7 \mathrm{~J} / \mathrm{cm}^{2} \quad$ energiasűrüségű, $\mathrm{N}=300$ lövésszámú impulzussorozat volt az ideális (4.(b) ábra). Az atomi erő mikroszkópiás mérésekből nyert vonalmetszetek igazolják, hogy a polikarbonát réteg vastagságával összemérhető, $50 \mathrm{~nm}$-es modulációs mélységü rendezett rácsokat sikerült létrehozni a felületen ().

(a)

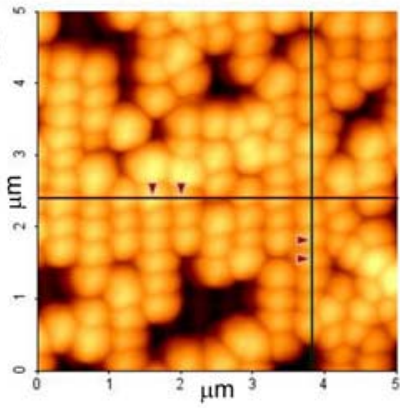

(b)

$$
\begin{aligned}
& \Lambda_{\text {rács }}^{1}=416 \mathrm{~nm} \\
& D_{\text {gömb }}^{1}=250 \mathrm{~nm}
\end{aligned}
$$

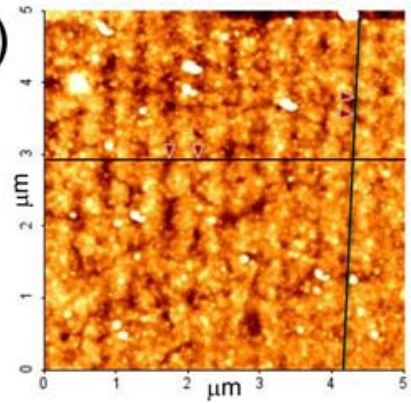

Vízszintes metszet
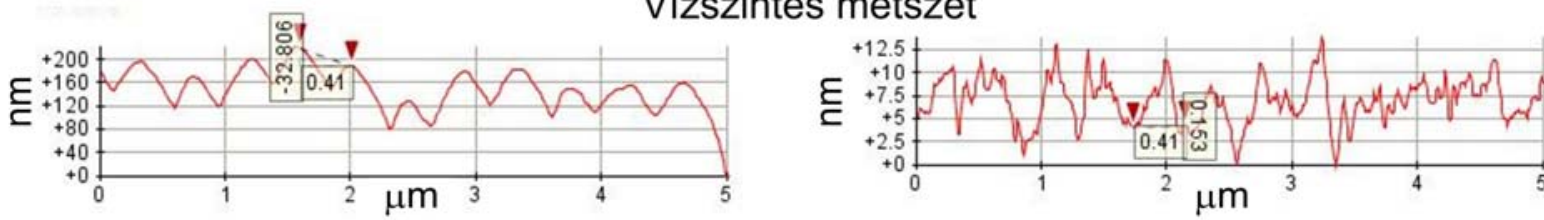

Függöleges metszet
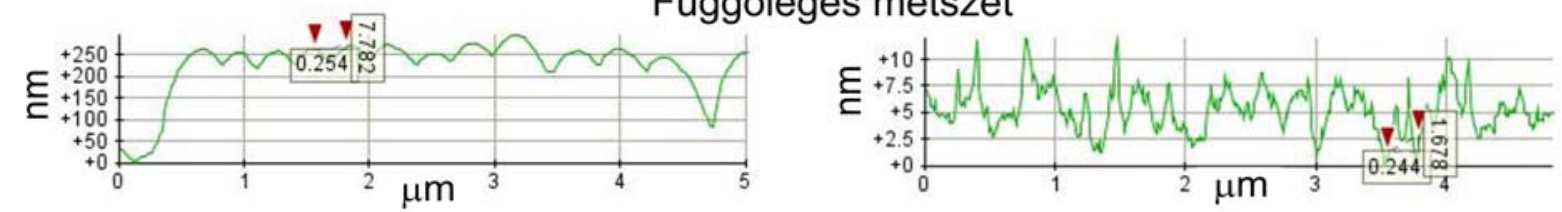

15. ábra. $250 \mathrm{~nm}$-es kvarc gömbök $416 \mathrm{~nm}$ periódusú polikarbonát rácson

Az ideális, a rácsok völgyeiben szorosan illeszkedően elhelyezkedő gömbsorok eléréséhez a forgatva bevonás során alkalmazott oldatmennyiségnek és forgási sebességértéknek és a gömbmérethez kell illeszkednie. Megfelelő rendezettségü, szorosan illeszkedő $\mathrm{D}_{\text {gömb }}^{1}=250 \mathrm{~nm}$ átmérőjű gömbökből álló mintázatot lehetett készíteni 2,5 $\mu$ l-es oldatmennyiséggel és 1000 fordulat/perc forgatási sebességgel mindkét rácsperióduson (15., 16. ábra). $\mathrm{A}_{\text {gömb }}^{2}=500 \mathrm{~nm}$ nagyobb méretü gömb egyenletes felviteléhez nagyobb anyagmennyiség és fordulatszám volt szükséges, ebben az esetben $4 \mu$ l-es oldatmennyiséggel és 1500 fordulat/perc forgatási sebességgel kaptunk hasonló jól elrendezett gömbsorozatokat (17. ábra). Az AFM képek alapján két karakterisztikus periódus azonosítható: vízszintes irányban a rácsperiódusnak megfelelő 416 vagy 833 nm-es érték, a másik pedig függőlegesen, a gömbsorozat hosszanti irányában mérhető, a gömbátmérővel egyező 250 vagy $500 \mathrm{~nm}$ méret. 
Az így létrehozott kvarc gömbsorozatokat kolloid litográfiás maszkként használva a KrF excimer lézer 193 nm-es hullámhosszú fényével, egy lövéssel világítottuk ki. A rövidebb hullámhossz előnyösebb ennél a gömbméret tartománynál, mert kisebb hullámhosszú fény jobban fókuszálható. Azon energiasűrüség, amely a fémfilmben lyukak létrehozására alkalmas, azonban a fémréteg és szubsztrát nem károsodik maradandóan, függ a kolloid gömb méretétöl.

$$
\Lambda_{\text {rács }}^{1}=416 \mathrm{~nm} \text {-es rácson elrendezett } \quad D_{\text {gömb }}^{1}=250 \mathrm{~nm} \quad \text { kvarc gömböket }
$$
$\mathrm{F}_{\mathrm{IL}}=100 \mathrm{~J} / \mathrm{cm}^{2}$ energiasürüséggel világítottuk ki. Ezekkel a paraméterekkel az AFM mérések szerint $\mathrm{d}_{\text {lyuk }}^{1}=100-200 \mathrm{~nm}$ átmérőjü, $\mathrm{t}_{\text {lyuk }}^{1}=5-10 \mathrm{~nm}$ mély gödröcskéket sikerült a felületben létrehozni. A lyukak egymás közötti távolságának mérésekor egyértelműen megjelenik a kolloid részekék átmérőjének és a rácsénak megfelelő periódus, de csak kis felületrészen sikerült egyenletes eloszlású lyukmintázattal borított tartományt mérni. (15. (b)-(c) ábra)

(a)

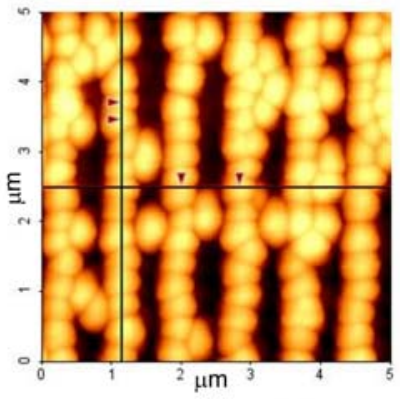

$$
\Lambda_{\text {rács }}^{2}=833 \mathrm{~nm}
$$$$
\mathrm{D}_{\text {gömb }}^{1}=250 \mathrm{~nm}
$$

(b)

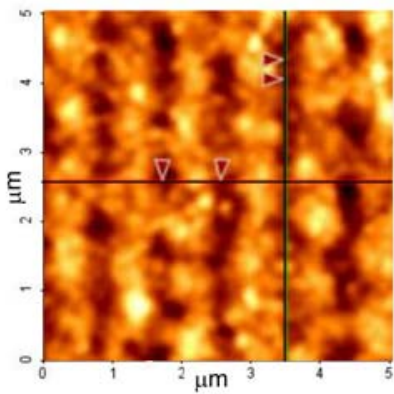

\section{Vízszintes metszet}
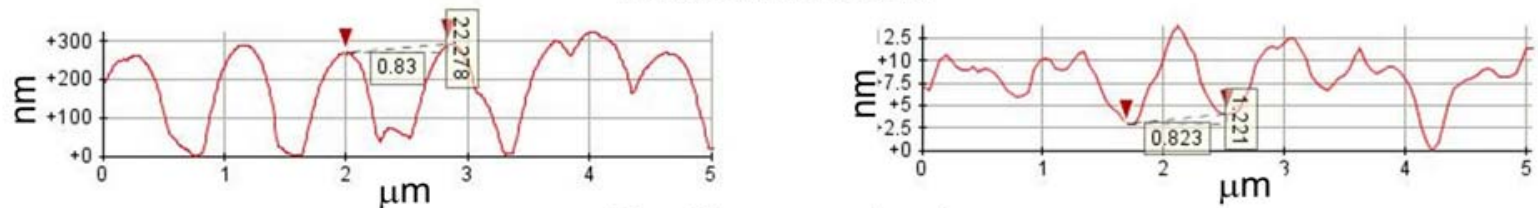

Függöleges metszet
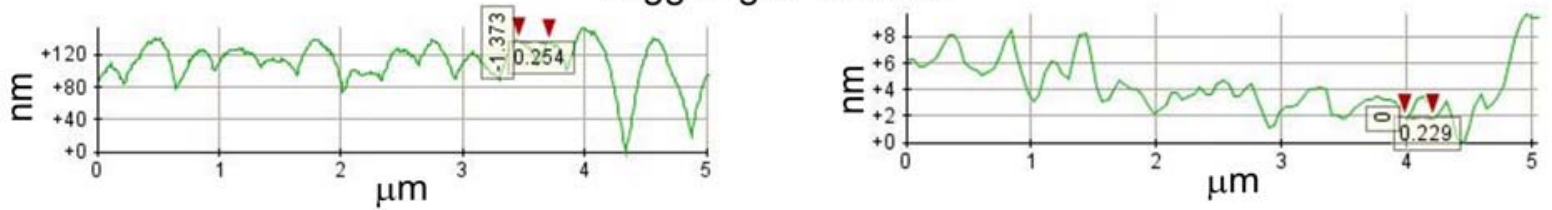

16. ábra. $250 \mathrm{~nm}$-es kvarc gömbök $833 \mathrm{~nm}$ periódusú polikarbonát rácson

$\mathrm{D}_{\text {gömb }}^{1}=250 \mathrm{~nm}$ átméröjü kvarc kolloid gömbökkel borított $\Lambda_{\text {rács }}^{2}=833 \mathrm{~nm}$ periódusú rácson is $F_{I L}^{2 a}=100 \mathrm{~J} / \mathrm{cm}^{2}$ volt a megfelelő megmunkáló energiasűrüség. Ebben az esetben az előző elrendezésből nyert lyukakhoz hasonló paraméterekkel rendelkező, $\mathrm{d}^{2 \mathrm{a}}{ }_{\text {lyuk }}=100-200 \mathrm{~nm}$ átmérőjü $\mathrm{t}_{\text {lyuk }}^{2 \mathrm{a}}=5-10 \mathrm{~nm}$ mélységü lyukakat mértünk AFM segítségével, a karakterisztikus periódusok itt is a gömbátmérő és a rácsperiódus értékének megfelelőek voltak (16. (a) és (b) ábra). 
A megjelenő periódusok karakterisztikussága és a lyukmélység nagyobb a $\Lambda_{\text {rács }}^{2}=833 \mathrm{~nm}$ periódusú rácsra felvitt, $\mathrm{D}_{\text {gömb }}^{2}=500 \mathrm{~nm}$-es gömbök előzőnél nagyobb, $\mathrm{F}^{2 \mathrm{~b}}{ }_{\mathrm{IL}}=150 \mathrm{~J} / \mathrm{cm}^{2}$ energiasürüséggel kivilágításakor. Ezen kísérleti feltételek mellett $\mathrm{d}^{2 \mathrm{~b}}{ }_{\text {lyuk }}=200-300 \mathrm{~nm}$ átmérőjü $\mathrm{t}^{2 \mathrm{~b}}{ }_{\text {lyuk }}=10-20 \mathrm{~nm}$ mélységü lyukakat mértünk atomi erő mikroszkóppal (17. (a), (b) ábra). Ezen határozottabb, a fémfilmben elhelyezkedő kétdimenziós lyukmintázatot használtuk plazmon rezonanciás spektroszkópiai mérések során [T4].
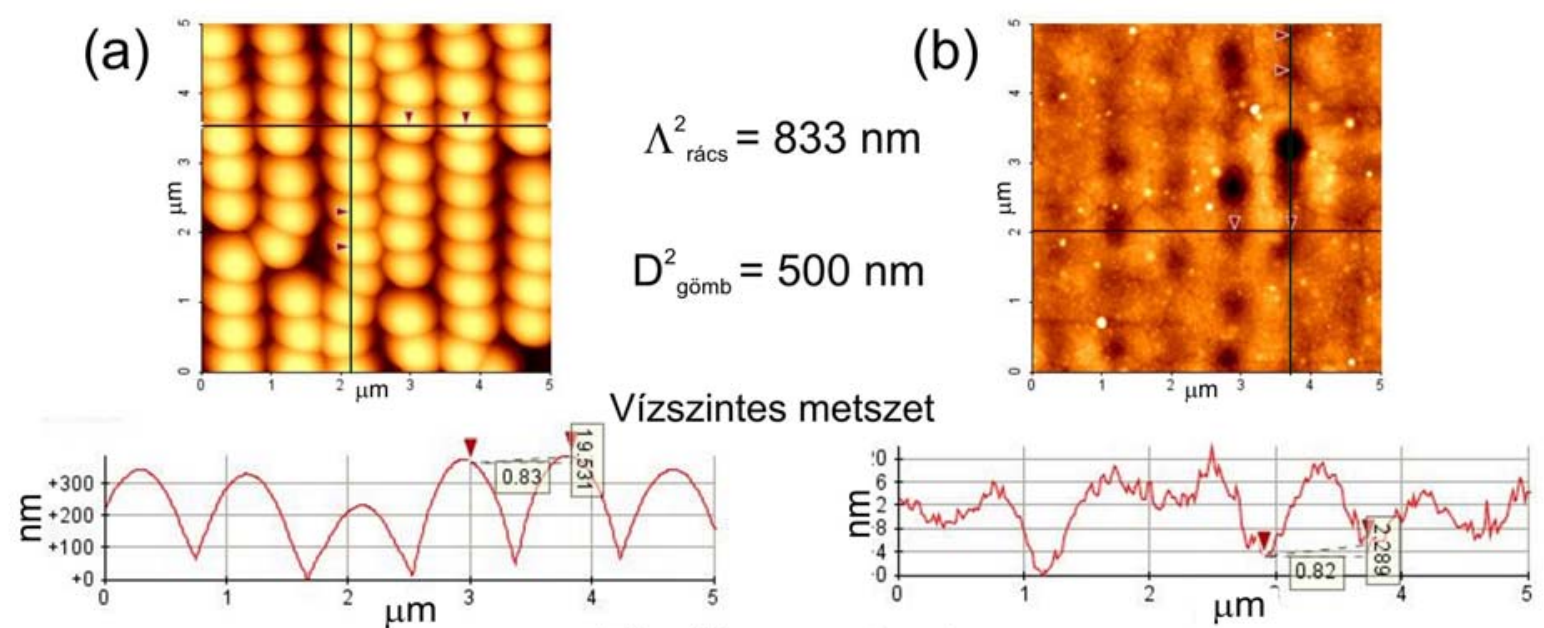

Függőleges metszet
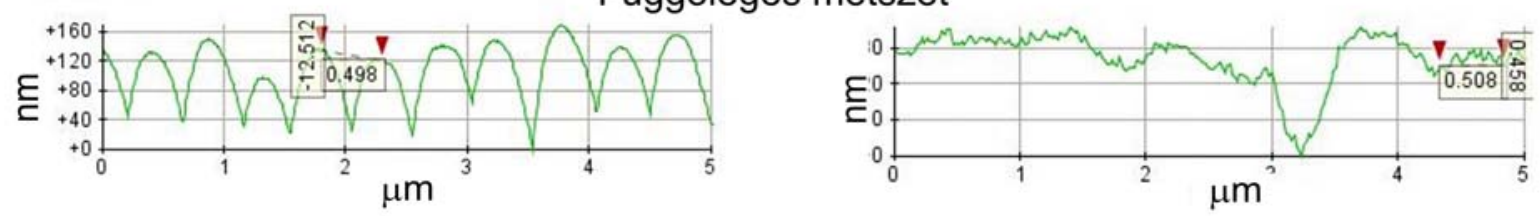

17. ábra. $500 \mathrm{~nm}$-es kvarc gömbök $833 \mathrm{~nm}$ periódusú polikarbonát rácson 


\section{Kolloid gömb litográfia}

Kolloid gömb monorétegek kétnyaláb interferometriás kivilágítását (KGMIK) vizsgáltam végeselem módszerrel. A szorosan illeszkedő hatszöges kétdimenziós kristályszerkezetben elhelyezkedő arany kolloid és Stöber-kvarc gömböket két interferáló nyalábbal világítottam ki. Ennek előnye a homogén megvilágításhoz képest, hogy az abban elérhető hatszöges mintázatszimmetria megtörhető, jellemzően négyszöges egységcellájú elrendezés hozható létre nagy felületen, kis költséggel.

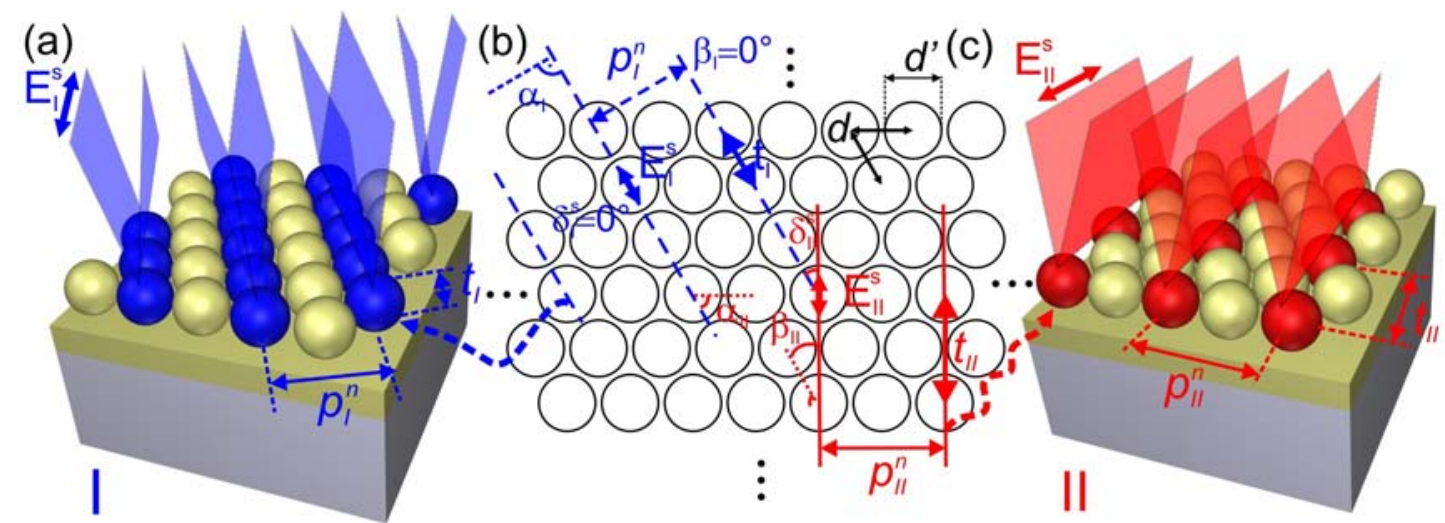

18. ábra. A KGMIK módszer elvi vázlata, mely a két relatív orientációt mutatja be. A 3D ábrákon kék illetve piros színnel kiemelt gömbök középpontja esik az interferencia maximumába.

A módszer lényege, hogy egy adott kolloid gömb monoréteget tökéletes szinkronizálással lineáris interferencia-mintázattal világítunk ki. A gyakorlati megvalósítás során a szinkronizáláshoz tökéletes hexagonális monorétegre és lineáris interferenciamintázatra van szükség, mivel a módszer átörökíti az egyszerü homogén nyalábbal végzett kolloidgömb litográfia érzékenységét a különböző rácshibákra, mint például az esetleges polidiszperzitás, diszlokációk vagy lyukak. Ezek a hibák egy ideális, tökéletesen homogén nyalábok kétnyaláb interferenciájának esetét tekintve is korlátozzák a nagyméretü felületek megmunkálását. Tökéletes monoréteg esetén a kivilágító lineáris interferencia-mintázat és a kolloid monoréteg helyzetének optimalizálásával biztosítható, hogy a periodikus intenzitásmoduláció és a kolloid gömbök által eredményezett közeltérbeli elektromágneses mező koncentráció egyszerre jelen legyen, így a periodikus intenzitás-eloszlás fókuszálása megvalósítható (18. ábra).

A KGMIK technikával egyszerre egy lépésben a teljes területrész módosítható, ahol a lineáris interferencia-mintázat és a kolloid monoréteg szinkronizációja megvalósul. A módszer mindkét litográfiai eljárás előnyeit egyesíti: az interferencia-mintázat lineáris szimmetriája és periódusa is megjelenik a hullámhossz mérettartományba eső lineáris 
periodikus mintázaton, míg a kolloid gömbök okozta intenzitás-koncentráció a hullámhossznál jóval kisebb felületrészeken jelenik meg.

A vizsgált kétnyalábos interferencialitográfia esetén a létrejövő vonalszerü mintázatot a nyalábok hullámhossza, beesési szöge határozza meg. Az első geometria paraméter a KGMIK technika során a nano-objektum mintázat lineáris interferencia-mintázattól örökölt $p$ periódusa (jellemzően a $100 \mathrm{~nm}-1000 \mathrm{~nm}$ nagyságrendben), mely a $\lambda$ hullámhosszal és $\theta$ beesési szöggel hangolható az (1) összefüggésnek megfelelően. Az interferenciacsíkok szélességének állításával a főmintázat mellett egy mellékmintázat is meghatározható.

A második jellemző paraméter a $t$ objektumok közti távolság, mely összemérhető a gömbök közötti $d$ távolsággal. A $t$ távolság a lineáris interferencia-mintázat és a gömbréteg relatív orientációjától függ adott monoréteg esetében. Azonos nagyságú kolloid gömböt és kivilágító hullámhosszat feltételezve az orientáció és az ennek megfelelő beesési szög változtatásával a lineáris interferencia-mintázat a gömbsereggel többféleképpen szinkronizálható, így megszámlálhatóan végtelen $t$ értéket lehet meghatározni. Ezekből a két legegyszerübb esetet vizsgáltam, mikor a kétnyaláb interferencia alkalmazásával két olyan egymástól eltérő geometria hozható létre, amelyek segítségével a legkisebb $t$ távolságok érhetőek el. A két geometriát római számokkal különböztettem meg, a hozzájuk kapcsolódó mennyiségeket is így jelölöm.

A két geometria leírása során használt irányokat minden esetben a szorosan illeszkedő hatszöges mintázat kétdimenziós kristályrácsának $(1,0,0)$ kristálytani irányához viszonyítom. A lineárisan polarizált nyalábok esetében s-polarizált nyalábbal dolgoztam minden esetben. Két-nyaláb interferencia esetén a beesési sík és az $(1,0,0)$ kristálytani irány szögét $\alpha_{i}$ jelöli, az interferencia-maximumok irányát pedig a $\beta_{i}=90^{\circ}-\alpha_{i}$ szög adja meg. Az elektromos tér oszcillációjának irányát a $\delta_{i}^{s}$ szög adja s-polarizációra, ez $\delta_{I}^{s}=0^{\circ}$, I típusú geometria esetén (18. ábra, kék kiemelés), II típusú geometria esetén pedig $\delta_{I I}^{s}=30^{\circ}$ (18. ábra, piros kiemelés). Ha a lineáris interferencia-mintázat párhuzamos az $(1,0,0)$ hexagonális kristálytani iránnyal, azaz $\beta_{I}=0^{\circ}$, az objektumköz $t$ távolság $t_{I}=d$. Ebben az esetben a periódus $p_{I}^{n}=n \cdot \sqrt{3} / 2 \cdot d$, mely mindig nagyobb a nano-objektumok közötti távolságnál, ha $n>1$. A gömbökkel összehangolt periódusú interferenciamintázathoz szükséges beesési szög:

$$
\theta_{I}^{n}=\arcsin \left(\frac{\lambda}{n \cdot \sqrt{3} \cdot d}\right)
$$


Amikor a lineáris interferenciamintázatot $\beta_{I I}=30^{\circ}$-kal elfordítjuk, a periódus $p_{I I}^{n}=n \cdot d / 2$, mely távolság szintén nagyobb a homogén kivilágításnál tapasztalható $d$ távolságtól, ha $n>1$. II típusú geometria esetén a $t$ távolság a gömbtávolságnál nagyobb, $t_{I I}=\sqrt{3} \cdot d$. A II típusú geometriában a megfelelő beesési szög:

$$
\theta_{I I}^{n}=\arcsin \left(\frac{\lambda}{n \cdot d}\right)
$$

A KGMIK dielektrikum és fém gömbök esetén is alkalmazható, de megfelelő minőségű monoréteg előállítása fém gömbökből kihívást jelent. Fém gömbök alkalmazása esetén a módszer előnye, hogy az ilyen részecskéknél megjelenő csatolások a $\theta$ beesési szög állításával is hangolható az interferencia mintázat változásával egy időben.

A harmadik karakterisztikus geometriai paraméter a lézerkezelt felület nanométeres nagyságrendbe eső a átmérője (1-100 nm), mely a kolloidgömb alatti lokális intenzitáseloszlás félértékszélességével összemérhető. Az elérhető félértékszélesség nagyságát a gömbök $d$ 'átméröje és a kivilágító fény hullámhossza határozza meg. Ezt a méretet gyakorlati megvalósítás során befolyásolja az alkalmazott intenzitás nagysága, és a megmunkálandó felület roncsolási küszöbenergia-sürüségének aránya a felület hővezetési jellemzői.

Fém gömbök lineárisan polarizált nyalábbal való kivilágítása esetén a kivilágított gömbök alatt egy karakterisztikus kettös szubstruktúra is kialakul, mely a $d_{0}$ paraméterrel jellemezhető. Szimmetria okokból ez a szubstruktúra a fény polarizációjával párhuzamosan jelenik meg, a bemutatott s-polarizáció esetén az interferenciamintázattal párhuzamosan. A $d_{0}$ paraméter az a értékével együtt változtatható a gömbátmérő, hullámhossz, alkalmazott teljesítménysürüség számértékeivel.

A módszer bemutatására arany vékonyfilmen elhelyezett arany és Stöber-kvarc gömbök modellezését mutatom be, de az eljárás más anyagokra, anyagpárokra is ugyanúgy alkalmazható [T5]. Az összehasonlítás alapjának megteremtésére először a merőlegesen beeső homogén nyalábbal való kivilágítást modelleztem (19. (a) és (d) valamint 20. ábra (a) ábrák). Ebben az esetben s-polarizált fény világít ki egy szorosan illeszkedő hatszöges, de nem érintkező gömbökből álló monoréteget, melyek egy NBK7 üveg szubsztráton lévő 45 nm-es arany filmen helyezkednek el. A gömbátmérőket oly mértékben csökkentettem, míg az $d$ ' átmérőjü arany kolloid gömbök alatt a kivilágító fény $532 \mathrm{~nm}$ hullámhosszán elérhető intenzitás nagyobb, mint a gömbök legközelebbi pontjánál. A megfelelő gömbátmérő a $250 \mathrm{~nm}$-es távolságnál $225 \mathrm{~nm}$ volt, a $100 \mathrm{~nm}$-es távolság esetén pedig $90 \mathrm{~nm}$-nek adódott. 
A homogén kivilágításnál a lineáris s-polarizáció miatt függőlegesen orientált osztott intenzitáseloszlás figyelhető meg. Ennek alapján megállapítható, hogy hasonló kettős lyuk jöhet létre minden egyes kolloid gömb alatt. Ez az intenzitáseloszlás már homogén kivilágítás esetén is függ az elektromos tér oszcillációja és a kristálytani $(1,0,0)$ irány által bezárt $\delta_{i}^{s}$ szögtől (19. ábra (a) és (d). Az I-es geometria esetén az elektromos tér a $t_{I}=d$ irányban végez rezgést a $\delta_{I}^{s}=0^{\circ}$ iránynak megfelelően (19. (a) ábra ), míg a II-es geometria esetén az elektromos tér rezgésiránya a $t_{I I}=\sqrt{3} \cdot d$ távolságban elhelyezkedő gömbök irányába történik a $\delta_{I I}^{s}=30^{\circ}$ szögnek megfelelően (19. (d) és 20. (a) ábra). Mindkét elrendezésben az intenzitáseloszlás mintázata őrzi a szorosan illeszkedő hatszöges réteg elrendezését, de a kettős lyukak az elektromos tér rezgésének különböző relatív iránya miatt a kettőződés más irányban történik az alapirányhoz képest.

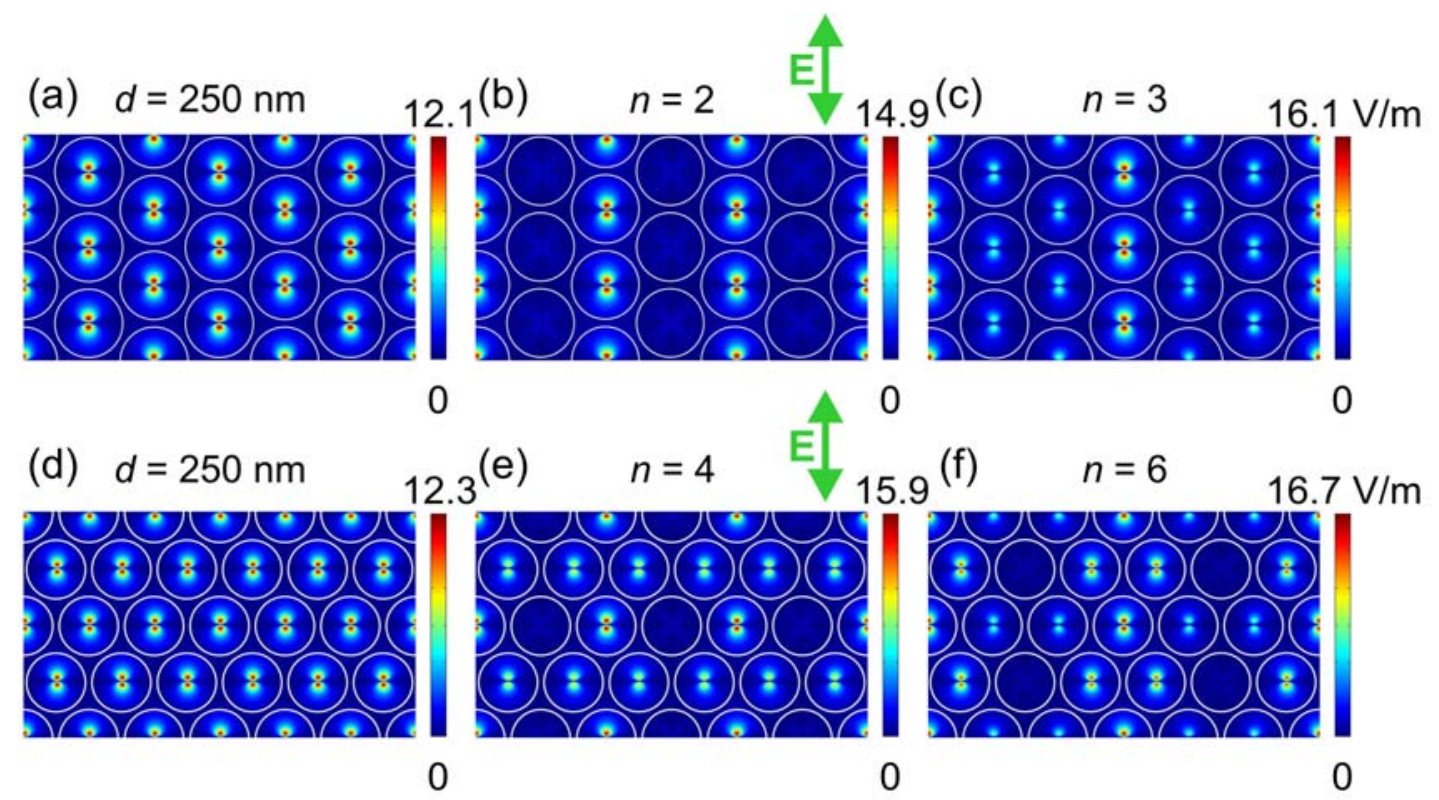

19. ábra. $250 \mathrm{~nm}$ távolságban elhelyezett, $532 \mathrm{~nm}$ hullámhosszú s-polarizált fénnyel kivilágított $225 \mathrm{~nm}$ átméröjủ arany kolloid gömb monorétegek alatti intenzitáseloszlás (a-c) I-es geometriában (d-f) II-es geometriában. Az intenzitáseloszlás (a, d) homogén illetve (b) $\mathrm{n}=2: \theta_{I}^{2}=37.9^{\circ}$, (c) $\mathrm{n}=3: \theta_{I}^{3}=24.2^{\circ}$, (e) $\mathrm{n}=4: \theta_{I I}^{4}=32.1^{\circ}$;és (f) $\mathrm{n}=6: \theta_{I I}^{6}=20.8^{\circ}$ szögeknek megfelelő kétnyalábos interferenciamintázat. A zöld nyíl a polarizáció irányát mutatja.

Kolloid monoréteget lineáris interferencia-mintázattal kivilágítva a megjelenő periodikus intenzitás-moduláció a hullámhossz és a beesési szög függvénye. Mivel spolarizált nyalábokkal világítottam ki a monoréteget, így az elektromos tér rezgésének iránya a $(1,0,0)$ kristálytani irányhoz képest $\delta_{I}^{s}=0^{\circ}$ volt I-es geometriában (19. (b) és (c) ábrák), II-es geometriában $\delta_{I I}^{s}=30^{\circ}$ (19. (e) és (f), 20. (b) és (c) ábrák). 
Először a $\beta_{i}$ relatív orientáció hatását vizsgáltam egymástól $250 \mathrm{~nm}$ távolságra elhelyezett $225 \mathrm{~nm}$ átméröjü arany kolloid gömbökön. A kolloidréteget $532 \mathrm{~nm}$ hullámhosszú fénnyel világítottam ki I-es és II-es geometriában (19. ábra (b) és (c) összevetve (e) és (f) részekkel). Ez az ábra a $p$ periódus beesési szöggel való hangolását is bemutatja: I-es geometriában az $n=2$ és $n=3$ esetnek megfelelő beesési szöggel érkeznek a nyalábok (19. ábra (b) és (c)), míg II-es geometriában a $n=4$ és $n=6$ esetnek megfelelően (19. ábra (e) és(f)). Ezekben az esetekben különböző mintázatok alakulnak ki az interferencia-maximumok alatt lévő $t_{I}=d$ illetve $t_{I I}=\sqrt{3} \cdot d$ távolságra elhelyezkedő kivilágított gömbök közelterében.

Az I-es geometriában a megkettőződött intenzitáseloszlás lyukpárja a közvetlenül egymás szomszédságában elhelyezkedő gömbök alatt alakul ki, ez esetben az interferenciamaximum és az elektromos tér rezgésének iránya is az $(1,0,0)$ kristálytani iránnyal $\left(\beta_{I}=\delta_{I}^{s}=0^{\circ}\right)$ párhuzamos. A $\theta_{I}^{2}=37.9^{\circ}$ beesési szögnek megfelelő $n=2$ eset periódusa $433 \mathrm{~nm}$ (19.(b) ábra), a $\theta_{I}^{3}=24.2^{\circ}$ szögnek megfelelő $n=3$ eset pedig $649.5 \mathrm{~nm}$ periódusú (19.(c) ábra), ezzel igazolható, hogy a két interferáló nyaláb beesési szögének változtatásával a nano-objektumok mintázatának periódusa is hangolható. Kisebb beesési szögnél egy másodlagos mintázat is kialakul a szélesebb interferencia-mintázat alatt elhelyezkedő szomszédos gömbsoron is. A megjelenő mintázat a kolloid gömbök fókuszáló hatásának és az interferencia-mintázattal modulált intenzitás-eloszlásnak együttes eredménye.
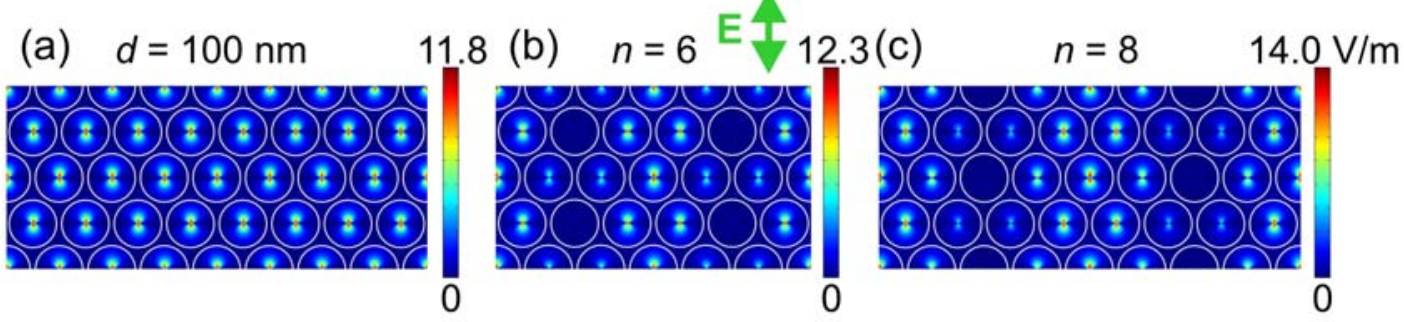

20. ábra. $100 \mathrm{~nm}$ távolságban elhelyezett, $532 \mathrm{~nm}$ hullámhosszú s-polarizált fénnyel kivilágított $90 \mathrm{~nm}$ átmérőjű arany kolloid gömb monorétegek alatti intenzitáseloszlás. Az intenzitáseloszlás (a) homogén illetve (b) $\mathrm{n}=6: \theta_{I I}^{6}=62.46^{\circ}$ és (c) $\mathrm{n}=8: \theta_{I I}^{8}=41.68^{\circ}$ szögeknek megfelelő kétnyalábos interferencia-mintázat. A zöld nyíl a polarizáció irányát mutatja.

A II-es geometria esetében lényegesen más mintázat figyelhető meg. A periódus a beesési szöggel hangolható, $250 \mathrm{~nm}$ távolságra elhelyezett kolloid gömbök esetén $500 \mathrm{~nm}$ periódus érhető el $\theta_{I I}^{4}=32.1^{\circ}$ beesési szögnél, ami az $n=4$ esetnek felel meg (19. (e) ábra), míg $750 \mathrm{~nm}$ periódus jelenik meg az $n=6$ esetnek megfelelő $\theta_{I I}^{6}=20.8^{\circ}$ szögnél (19. (f) ábra). A II-es geometriában már kisebb periódusnál is megjelenik a másodlagos 
mintázat, ami a beesési szög csökkentésével kiszélesedik az interferencia-mintázat szélesedésével, a I-es geometriához hasonlóan (19. ábra). A mintázat jellege különböző, az $(1,0,0)$ kristálytani irányhoz képest mérhető $\beta_{I I}=30^{\circ}$ szögben álló lineáris interferenciamintázatnak és a $\delta_{I I}^{s}=30^{\circ}$ szögben álló elektromos tér rezgésirányának megfelelöen. A másodlagos mintázat a hasonló beesési szögek esetében a II-es geometriánál határozottabban jelenik meg, a geometriai elrendezésből kifolyólag nagyobb felületen mutatható ki, így ebben az elrendezésben összetettebb mintázat hozható létre.

A $90 \mathrm{~nm}$ átméröjü gömböket $100 \mathrm{~nm}$ távolságra helyezve egymástól és a fentiekhez hasonlóan kivilágítva a nagyobb kolloid gömbök kivilágításával összehasonlítva a gömbméret hatásának szerepe vizsgálható. Ebben az esetben is vizsgáltam a homogén nyalábbal való kivilágítás esetét, valamint az $n=6$ és $n=8$ esetnek megfelelő $\theta_{I I}^{6}=62.46^{\circ}$ és $\theta_{I I}^{8}=41.68^{\circ}$ beesési szögekkel. A megfelelö kivilágításokat összehasonlítva látható, hogy a jellemző, $p, t$, $a$ és $d_{0}$ paraméterek együttesen változtathatóak a kolloid gömb átméröjének hangolásával. $\mathrm{A}$ kisebb kolloid gömb méret minden paraméterben jelentős csökkenést jelent, amint azt az ábra és a számszerü összesítés mutatja (20. és 21. ábra).
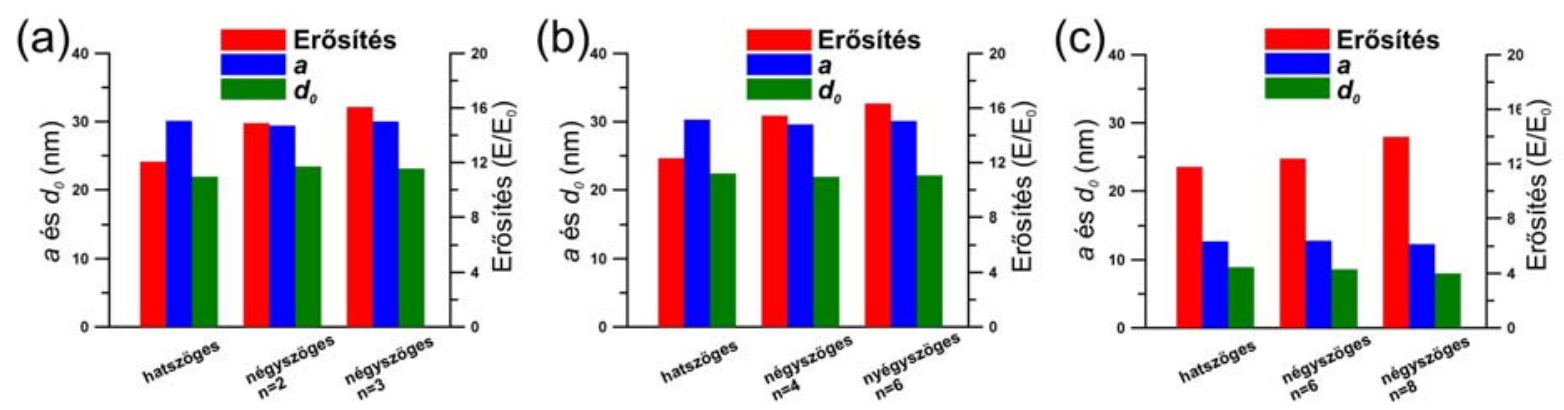

21. ábra. Az $a$ és $d_{0}$ paraméterek összehasonlítása az egyes kivilágítási esetekben.

A félértékszélességből származó $a$ és a kettőségből adódó $d_{0}$ paraméterek összehasonlításához számszerü összesítést is végeztem (21. ábra). A közeltérbeli intenzitások összehasonlítása a KGMIK módszer előnyét igazolja: a lineáris interferencia-mintázat esetén a gömbök között fellépő csatolás csökken, ennek köszönhetően nagyobb erősítés érhető el a módszerrel. Az elérhető félértékszélességnek megfelelő $a$ paraméter az egyes esetekben összemérhető, a homogén nyalábbal és az lineáris interferencia-mintázattal való kivilágítást összehasonlítva. Adott gömbméretet tekintve kettősség mértéke, a $d_{0}$ paraméter is gyakorlatilag független a kivilágítás milyenségétől, mert s-polarizált fény esetén a kettőződés hossztengelye az elektromos tér rezgésének irányával párhuzamos.

Stöber-kvarc kolloid részecskék esetén a közeltérbeli elektromágneses tér más képet mutat. Különböző átmérőjü (500, 250 és $100 \mathrm{~nm}$ ) Stöber-kvarc kolloid gömböket helyezve 
$45 \mathrm{~nm}$ aranyfilmre a hullámhossznak, kivilágítás módjának és a polarizációnak a létrehozható intenzitás-modulációra gyakorolt hatását vizsgáltam. Ebben az esetben is merőlegesen beeső, illetve a KGMIK módszerrel világítottam ki az alkalmazott modelleket. KGMIK esetén mindegyik esetben a II-es típusú geometriai elrendezést választottam $n=6$ esetre, a nyalábok beesési szögét pedig az adott gömbátmérőnek megfelelő periódushoz illesztettem a fém gömbök kivilágításához hasonlóan 532 és $400 \mathrm{~nm}$ hullámhosszakra az (1) és (19) összefüggéseknek megfelelően. A modellezés során a közeltérbeli metszeteken a létrehozható, jellemzően elliptikus nanolyukak függőleges $a$ vízszintes és $b$ függőleges tengelyeit mértem (25. (a) és (b) ábrák), a normalizált elektromos téreloszlás félértékszélességének mérésével [T6].

(a)

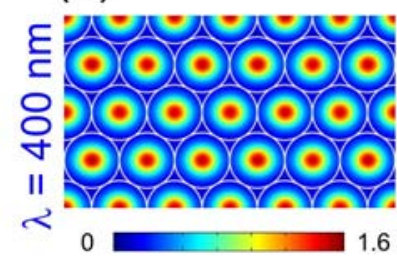

(e)

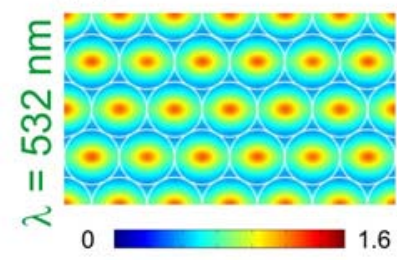

\section{lineáris polarizáció}

(b)

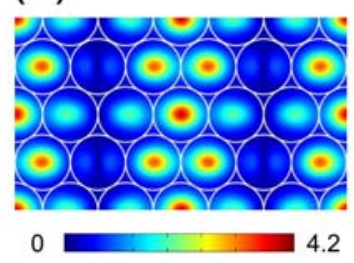

(f)

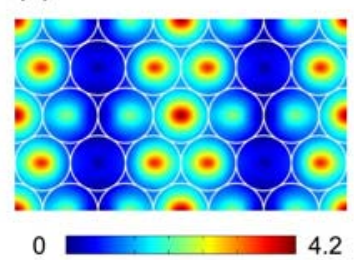

(c)

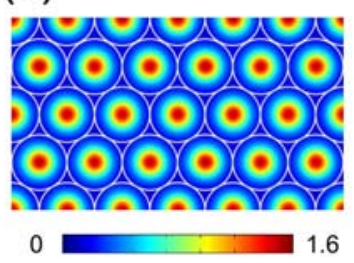

(g)

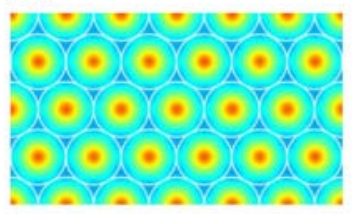

0 cirkuláris polarizáció

(d)

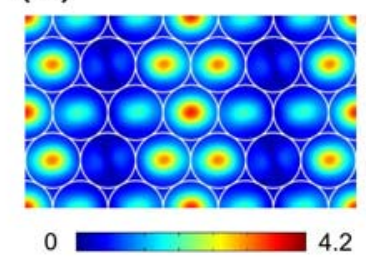

(h)

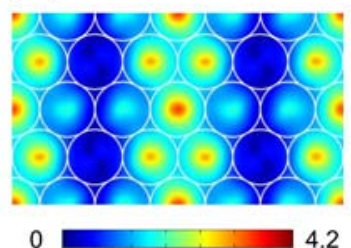

22. ábra. Intenzitáseloszlás $500 \mathrm{~nm}$ átmérőjü Stöber-kvarc kolloid gömbök alatt $400 \mathrm{~nm}$ (felső sor) és $532 \mathrm{~nm}$ (alsó sor) hullámhosszú lineáris (első két oszlop) és cirkuláris (harmadik és negyedik oszlop) polarizációjú fénnyel való kivilágítás (a, c, e, g) merőlegesen beeső nyaláb és (b, d, f, h) KGMIK elrendezés esetén.

Homogén kivilágítás esetén a fém gömbökhöz hasonlóan azonos, de nem kettőzött lyukak hozhatók létre a felületen (22.-24. (a), (c) (e) és (g) ábrák). Lineáris s-polarizáció esetén a lyukak az elektromos tér rezgési irányára merőlegesen kissé megnyúltak. A Stöberkvarc gömbök esetén nem figyelhető meg kettőződés a polarizáció irányában. Az ellipticitás a gömbátmérővel nem folytonosan változik, és határozottabban mérhető $532 \mathrm{~nm}$ hullámhosszú fénnyel való kivilágítás esetén (összehasonlítva 22.-24. (a) és (e) ábrákat valamint ezeknek megfelelő számszerű értékeket 25. (a)-(c) ábrán). A merőlegesen beeső cirkuláris polarizáció azonos objektumokat hoz létre minden gömb alatt, számottevő megnyúlás nem tapasztalható (22.-24. (e) és (g) ábrák, valamint 25. (a)-(c) értékek). Mindkét polarizáció esetén 
megállapítható, hogy 500 nm-es átmérőjü kolloid gömbök esetén a hullámhossz 400 nm-ről 532 nm-re való növelésével az objektumok mérete is megnő, míg 250 és $100 \mathrm{~nm}$ átmérőjü gömbök esetén tipikus objektum-méret közel azonos vagy enyhe méretcsökkenés mérhető.

(a)

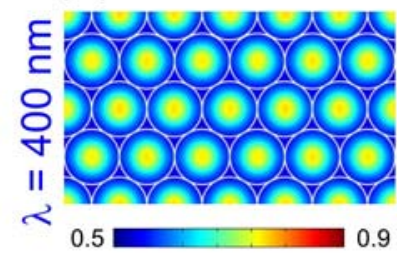

(e)

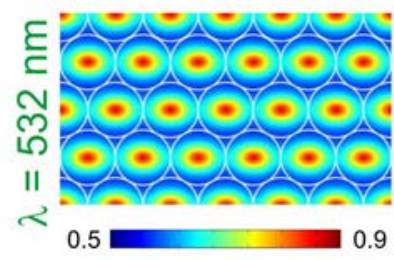

lineáris polarizáció

(b)

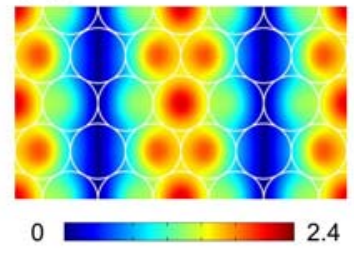

(f)

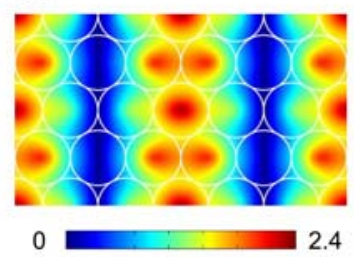

cirkuláris polarizáció

(c)

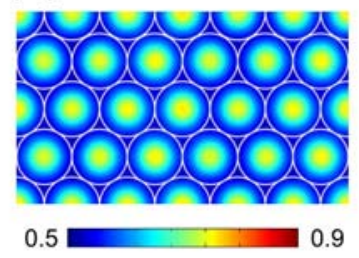

(g)

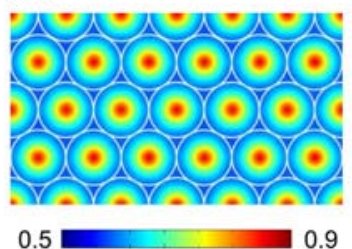

(d)

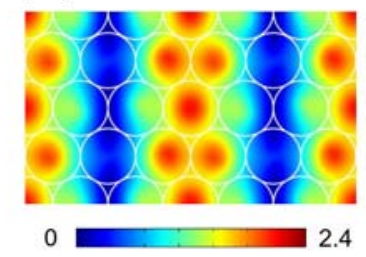

(h)

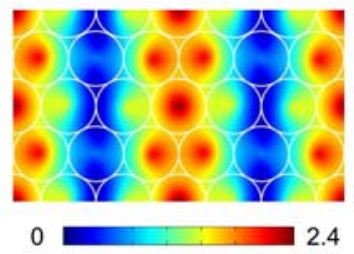

23. ábra. Intenzitáseloszlás $250 \mathrm{~nm}$ átmérőjű Stöber-kvarc kolloid gömbök alatt $400 \mathrm{~nm}$ és 532 nm (alsó sor) hullámhosszú lineáris s- (első két oszlop) és cirkuláris (harmadik és negyedik oszlop) polarizációjú fénnyel való kivilágítás (a, c, e, g) merőlegesen beeső nyaláb és (b, d, f, h) KGMIK elrendezés esetén.

KGMIK kivilágítás esetén lineáris mintázat hozható létre a felületen a fém gömböknél tapasztaltakhoz hasonlóan, bár az egyes gömbök alatt elérhető mintázat jelentősen eltér a gömbök dielektrikum anyaga miatt (22.-24. (b), (d) (f) és (h) ábrák). Elliptikus nanolyukak hozhatók létre s-polarizáció esetén (22.-24. ábrák (b) és (f)), cirkuláris polarizáció esetén pedig a köralakot jobban közelítő nanolyukak és nanoholdak jelennek meg a felületen. Érdekes jelenség, hogy kisebb gömbméret esetén $(250 \mathrm{~nm}, 100 \mathrm{~nm})$ az a méretparaméter kisebb 532 nm-es kivilágítás esetén a nagyobb hullámhossz ellenére, míg a B méretparaméter esetén hasonló tendencia nem figyelhető meg. Az elektromos tér rezgési irányában megjelenő kisebb megnyúlás ezen a hullámhosszon, mely az arany rezonancia-hullámhosszát megközelíti, az arany filmben keltett dipólusok elektromos téreloszlásával függ össze. Ennek megfelelően $532 \mathrm{~nm}$ hullámhossz esetén $400 \mathrm{~nm}$-es esethez képest egy adott gömbméretre jobban elkülönülő nano-objektumok jelennek meg.

Az 500 nm-es gömbök homogén kivilágítása egyenletes eloszlású, polarizáció- és hullámhosszfüggő méretű nanolyukakat eredményez. Lineáris s-polarizációjú $400 \mathrm{~nm}$-es hullámhosszal való kivilágítása esetén $a=209 \mathrm{~nm}$ és $b=228 \mathrm{~nm}$ méretű majdnem kör alakú nanolyuk jelenik meg (22. (a) és 25. (a)-(c) ábrák), $532 \mathrm{~nm}$ kivilágítás esetén pedig elliptikus, 
$a=209 \mathrm{~nm}$ és $b=316 \mathrm{~nm}$ méretek mérhetőek (22. (e) ábra). Cirkuláris polarizáció esetén kör alakú, $400 \mathrm{~nm}$-re $a=217 \mathrm{~nm}, 532 \mathrm{~nm}$-re $a=239$ nm átmérőjü nano-objektumok hozhatóak létre (22. (c) és $(\mathrm{g}))$.

KGMIK kivilágítás esetén $\theta_{I I}^{6}=7.7^{\circ}$ volt a beesési szög $400 \mathrm{~nm}$ (22. (b) és (d) ábrák) és $\theta_{I I}^{6}=10.2^{\circ} 532 \mathrm{~nm}$ esetén (22. (f) és (h) ábrák), a maximumhelyek így $t_{I I}=866 \mathrm{~nm}$ távolságra $p_{I I}^{6}=1500 \mathrm{~nm}$ periódussal helyezkednek el az $\mathrm{n}=6$ esetnek megfelelöen. Ebben az esetben a komplex lineáris mintázat a fỏmaximumok alatt elhelyezkedő elliptikus nanolyukakból áll, melyek 400 nm-es kivilágítás esetén vízszintes irányban megnyúltak a homogén kivilágításhoz képest mindkét polarizáció esetén (22. (a) és (b), (c) és (d) ábrák, valamint 25. (a)-(c) ábrák értékeinek összehasonlítása alapján). Az 532 nm hullámhossz és lineáris s-polarizáció esetén a megnyúlás kisebb, míg cirkuláris polarizáció alkalmazása a homogén kivilágításhoz hasonlóan kör alakú objektumokat hoz létre (22. (e) és (f), (g) és (h) ábrák, valamint 25. (a)-(c) ábrák értékeinek összehasonlítása alapján). A központi lyukmintázatot két oldalról egy másodlagos, nanoholdszerü objektumokból képezett mintázat veszi körbe, ezen objektumok középpontjai hatszöges szimmetriában helyezkednek el a központi maximum körül lineáris s-polarizációra. Cirkuláris polarizáció esetén a középponti maximum alakja jobban közelíti a kört, és a mellékmaximumok is sziromszerü alakot vesznek fel (22. ábrán (b) és (d), (f) és (h) összehasonlítása alapján). Hasonló alakváltozás figyelhető meg 400 nm-ről 532 nm-re való váltás esetén, így az a konklúzió vonható le, hogy 532 nm hullámhosszú, cirkuláris polarizációjú fénnyel állítható elő a legváltozatosabb felületi struktúra [T6].

A $250 \mathrm{~nm}$ átmérőjü kvarc gömbök homogén kivilágítása esetén a hatszöges elrendezésű nanolyukak méretparamétere csökken 400 nm-ről 532 nm hullámhosszra való váltás esetén. Lineáris s-polarizáció esetén a nano-objektumnak nemcsak mérete, hanem az alakja is változik, az $500 \mathrm{~nm}$ átmérőjü kolloid részecskékhez hasonlóan (23. (a) és (e) ábrák). A 400 nm hullámhosszú kivilágítás esetén kör alakú, a = 134 nm átmérőjü lyukak hozhatók létre, $532 \mathrm{~nm}$-en pedig $\mathrm{a}=96 \mathrm{~nm}, \mathrm{~b}=121 \mathrm{~nm}$ tengelyü elliptikus objektum. Cirkuláris polarizáció esetén mindkét hullámhosszra kör alakú, 400 nm-re a =134 nm, 532 nm-re $\mathrm{a}=112 \mathrm{~nm}$ átmérőjű lyukak jelennek meg (23. (c) és (g) ábrák), a hullámhossz változtatásával járó méretváltozás iránya az 500 nm-es gömbökhöz képest megfordul.

KGMIK kivilágításban a $p_{I I}^{6}=750 \mathrm{~nm}$ periódusú, $t_{I I}=433 \mathrm{~nm}$ távolságra elhelyezkedő mintázathoz $400 \mathrm{~nm}$ esetén $\theta_{I I}^{6}=15,5^{\circ}$ (23. (b) és (d) ábrák), $532 \mathrm{~nm}$ esetén $\theta_{I I}^{6}=20,8^{\circ}$ (23. (f) és (h) ábrák) beesési szöget állítottam be. A komplex mintázat ez esetben 
is kerek objektumokból áll az 500 nm átméröjü gömbökhöz hasonlóan, de a főmaximumok két oldalán lévő szomszédos mellékmaximumok a gömbök és a hordozófelület közti érintkezési ponttól a középponti maximum felel tolódnak el.

(a)

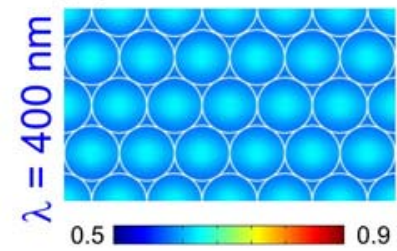

(e)

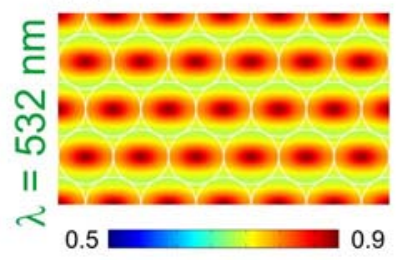

lineáris polarizáció

(b)

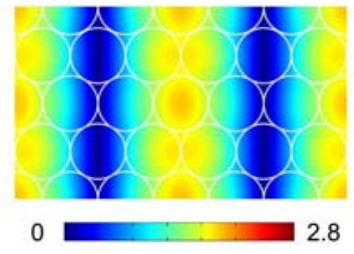

(f)

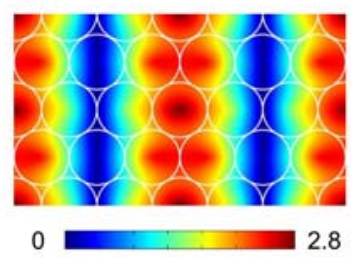

cirkuláris polarizáció

(c)

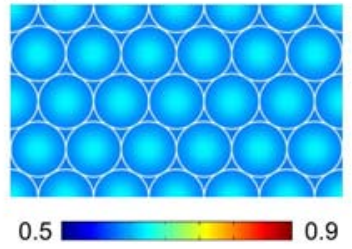

(g)

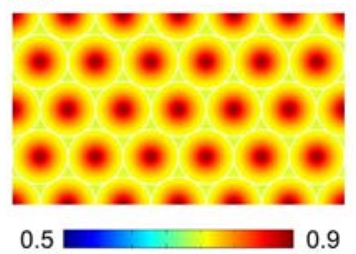

(d)

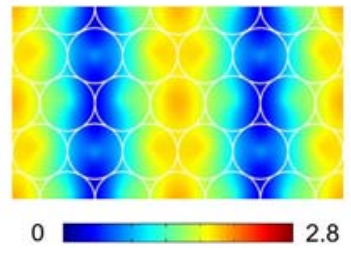

(h)

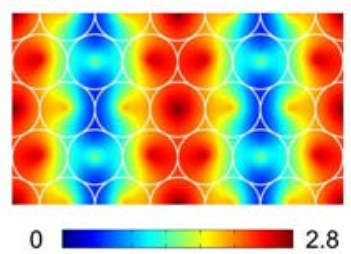

24. ábra. Intenzitáseloszlás $100 \mathrm{~nm}$ átmérőjü Stöber-kvarc kolloid gömbök alatt $400 \mathrm{~nm}$ és $532 \mathrm{~nm}$ (alsó sor) hullámhosszú lineáris (első két oszlop) és cirkuláris (harmadik és negyedik sozlop) polarizációjú fénnyel való kivilágítás (a, c, e, g) merőlegesen beeső nyaláb és (b, d, f, h) KGMIK elrendezés esetén.

A 400 nm-es hullámhosszú fénnyel történő kivilágítás esetén a nano-objektumok a fémgömbök esetéhez hasonlóan az elektromos tér rezgési irányában megnyúltak (23. (b) ábra), ez a megnyúlás cirkuláris polarizáció esetén kevésbé hangsúlyos (23. (b) és (d) ábra, valamint 25. (a)-(c) értékek összehasonlítása alapján). Az 532 nm KGMIK kivilágítás esetén a lyukak megnyúlása érdekes módon az elektromos tér rezgési irányára merőlegesen történik a homogén kivilágításhoz hasonlóan (23. (e) és (f) ábra, valamint 25. (a)-(c) értékek összehasonlítása alapján). Ezzel ellentétben cirkuláris polarizációra a megnyúlás az elektromos tér rezgésirányában történik, a 400 nm-es esethez hasonlóan ((23. (d) és (h) ábra, valamint 25. (a)-(c) értékek összehasonlítása alapján).

A $100 \mathrm{~nm}$ átméröjü kvarc gömbök esetén a homogén kivilágítással létrehozható egyenletes elrendezésű lyukak mérete és alakja jelentősen függ a hullámhossztól és a polarizációtól. Mindkét alkalmazott hullámhossz esetén lineáris s-polarizációra az elektromos tér rezgési irányára merőleges megnyúlást tapasztaltam. A tengelyméretek aránya $(\mathrm{a}=53 \mathrm{~nm}$ és $\mathrm{b}=65 \mathrm{~nm})$ kismértékű megnyúlást mutat $400 \mathrm{~nm}$-re, míg $532 \mathrm{~nm}$ esetén $(\mathrm{a}=35 \mathrm{~nm}$ és $\mathrm{b}=65 \mathrm{~nm}$ ) a megnyúlás határozottabb (23. (a) és (e) ábrák és 25. (a)-(c) értékek összehasonlításából). Cirkuláris polarizációjú fény esetén a nagyobb gömbméretekhez 
hasonlóan kör alakú lyukak jelennek meg mindkét hullámhosszon, de a hullámhosszváltást kisebb méretváltozás kíséri ( $\mathrm{a}=57 \mathrm{~nm} 400 \mathrm{~nm}$ és a = $42 \mathrm{~nm} 532 \mathrm{~nm}$ hullámhosszon).

A KGMIK kivilágítás realizálása során $400 \mathrm{~nm}$ esetén $\theta_{I I}^{6}=41,8^{\circ}$, illetve $532 \mathrm{~nm}$ esetén $\theta_{I I}^{6}=62.5^{\circ}$ beesési szög szükséges ahhoz, hogy az interferencia-mintázat jól illeszkedjen az $\mathrm{n}=6$ esetnek megfelelő $p_{I I}^{6}=300 \mathrm{~nm}$ periódushoz, ekkor a fömaximumok távolsága $t_{I I}=173 \mathrm{~nm}$. A kisebb gömbméret miatt a komplex mintázat kevésbé látványos ebben az esetben, a főmaximumok melletti mintázat kevésbé különül el, mint a nagyobb gömbméretek esetén. A $400 \mathrm{~nm}$ hullámhosszú fénnyel kivilágítva a monoréteget, szinte folytonos csíkok jönnek létre gyenge szub-struktúrával, ahol az egyes nano-objektumok az elektromos tér rezgési irányában erősen megnyúltak (24. (b), (d) és 25. (a)-(c) ábra). Számottevő szubstruktúra csak 532 nm-es kivilágítás esetén figyelhető meg (24. (f), (h) ábrák). A központi maximum alatt elhelyezkedő nano-objektumok az egymás közelében elhelyezkedő gömbök közelterének átfedése miatt az elektromos tér irányára merőleges megnyúlt alakot vesznek fel (24. (f) ábra). Cirkuláris polarizáció esetén a $250 \mathrm{~nm}$ átméröjü gömbökhöz hasonlóan az elektromos tér rezgési irányával megegyező kismértékủ megnyúlás tapasztalható, és komplex mintázat is megjelenik. (23. (h) és 24. (h) ábrák összehasonlítása alapján). Kis nano-objektum csoportok csak 532 nm hullámhosszú, cirkuláris polarizációjú fénnyel való kivilágítás esetén hozhatók létre $100 \mathrm{~nm}$ átmérőjü kolloid gömbök esetén (24. (h) ábra).

Az eredmények számszerű elemzéséből megállapítható, hogy a fent meghatározott ellipticitást a kivilágítás körülményei alapvetően befolyásolják (25. (c) ábra). Cirkuláris polarizációval való homogén kivilágítás minden esetben kör alakú objektumokat eredményez, azaz az ellipticitás ezen esetekben a 0 értéket közelíti (25. (c) ábra négyzethálós mintázatú oszlopai). A homogén kivilágítás lineáris s-polarizáció esetén mindkét vizsgált hullámhossz értékre hasonló ellipticitást eredményez: 250 nm-es átmérőnél a legkisebbek az értékek, azaz ebben az esetben közelítik legjobban a kör alakot a nano-objektumok (25. (c) csíkos mintázatú oszlopai). Az 532 nm-es hullámhosszúságú fénnyel kivilágításkor mindegyik gömbméret esetén nagyobb az ellipticitás értéke (25. (c) ábra kék és zöld oszlopait összehasonlítva).

A 400 nm-es fénnyel megvalósított KGMIK esetén a gömbméret változtatásával az ellipticitás pozitív értékekről negatív értékekre vált, azaz az objektumok megnyúlása az elektromos tér rezgésére merőleges irányból azzal párhuzamosra vált (25. (c) ábra kék oszlopai). Az $532 \mathrm{~nm}$-es kivilágítás esetén ez a tendencia polarizációfüggő, lineáris 
s-polarizáció esetén a nano-objektumok vízszintesen elnyújtottá válnak (25. (c) ábra zöld csíkos oszlopai), cirkuláris polarizáció esetén pedig az átmérő csökkenésével inkább függőleges irányban nyúlnak meg (25. (c) ábra zöld négyzethálós oszlopai).

(a)

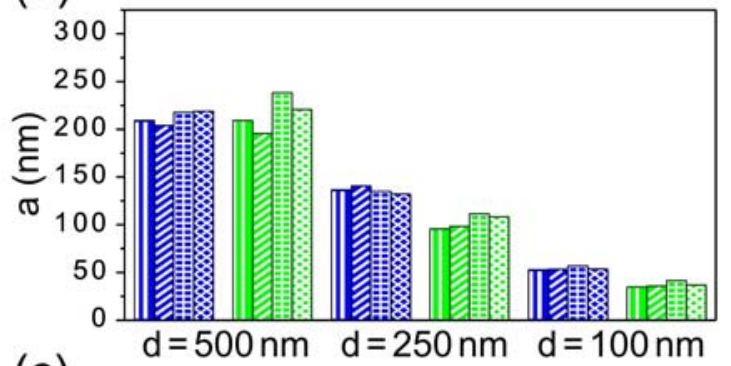

(c)

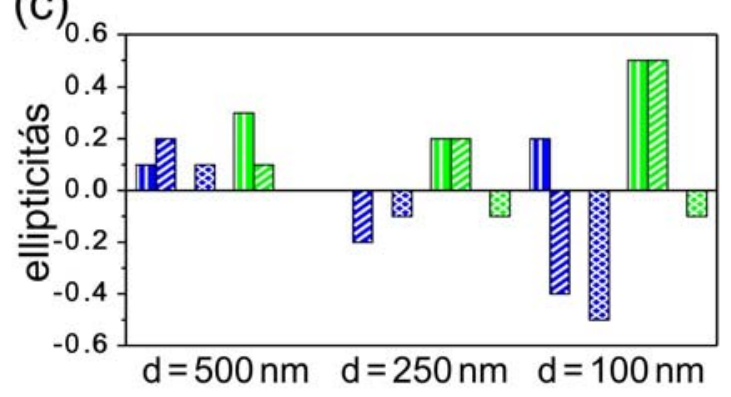

(b)

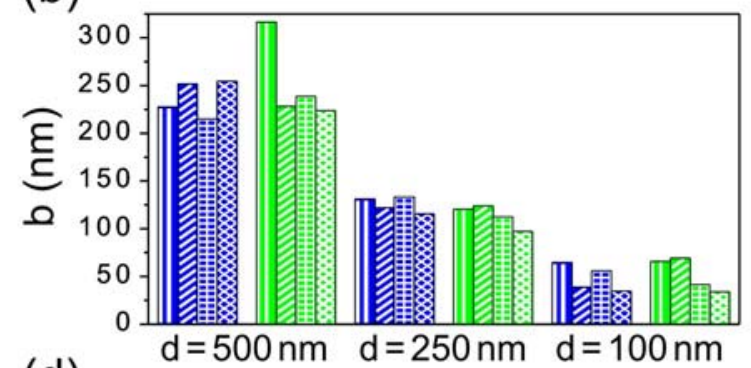

(d)

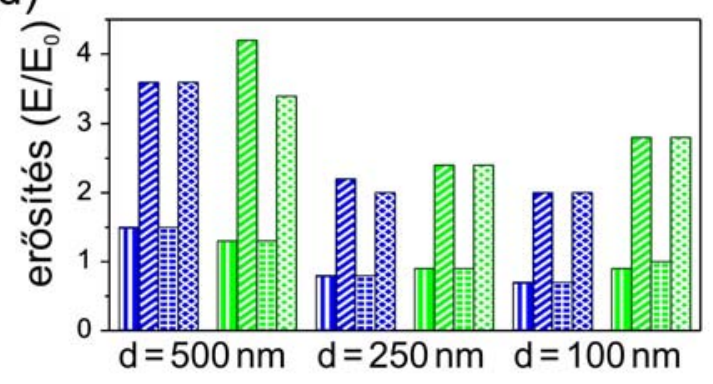

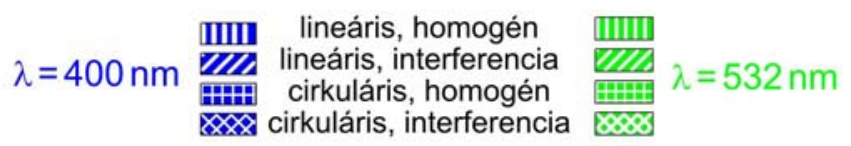

25. ábra. Az elliptikus lyukak (a) $a$ függőleges és (b) $b$ vízszintes tengelyméretei, (c) a $(b-a) / b$ ellipticitást jellemző paraméter (d) közeltérbeli erösítés az egyes esetekben.

KGMIK geometriában az elektromos tér erősítése nagyobb, mint homogén kivilágítás esetén mindkét polarizáció és hullámhossz esetén. (25. (d) ábra), ami lényeges előnyt jelent a homogén kivilágításhoz képest. A 400 nm hullámhosszú fénnyel kivilágítás esetén az erōsítés a gömbátmérővel csökken, azaz a nagyobb gömbök polarizációtól függetlenül jobban fókuszálják a fényt (25. (d) ábra kék oszlopai). A $532 \mathrm{~nm}$ esetén nem monoton a függés, 250 nm-re való csökkenés esetén az erősítés is csökken, 100 nm-re való csökkenéskor kissé megnövekedik homogén és interferencia kivilágítás esetén egyaránt (25. (d) ábra zöld oszlopai).

\subsection{Plazmonikus struktúrák plazmon rezonancia karakterisztikájának vizsgálata}

Fémes rácsok SPR vizsgálata

Egyetlen, az elsődleges plazmon rezonanciának megfelelő $\varphi_{\text {elemi }}$ csúcs mérhető sima filmek plazmon rezonancia görbéjén, ami azt jelzi, hogy ilyen esetben egyetlen $K_{\text {plazmon }}$ 
hullámvektorú plazmon gerjeszthető a fényterjedés irányában. Rács esetén a csatolt plazmonnak megfelelö $\varphi_{\text {csatolt }}<\varphi_{\text {elsödleges }}$ rezonancia-minimum is megfigyelhetö. A $\varphi_{\text {elemi }}$ várható rezonancia-minimumot megmunkálatlan film esetén, az ennek megfelelő elsőrendü csatolásból adódó $\gamma_{\text {csatolas }}^{n=1}$ irányt és a szükséges minimális $a_{\text {csatolas }}^{n=1}$ modulációs amplitúdó 4.4 alfejezetben felsorolt összefüggések alapján kiszámolt értékeit az egyes rétegpárokra/mintafelületekre a 2 . táblázatba foglaltam.

(a)

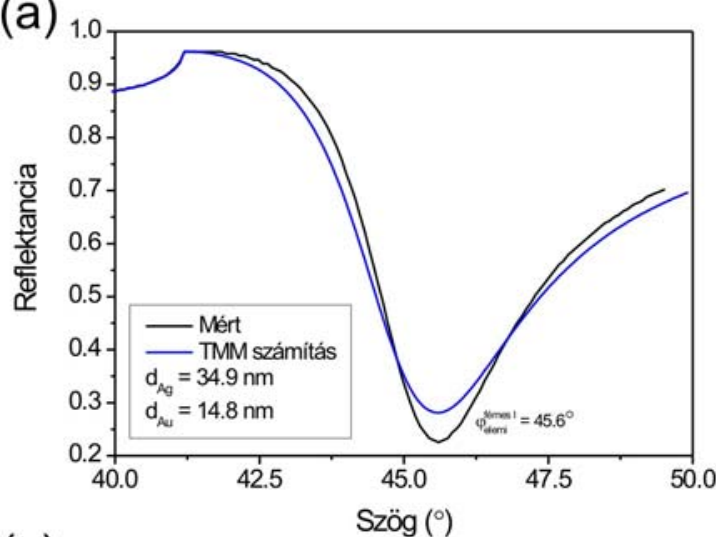

(c)

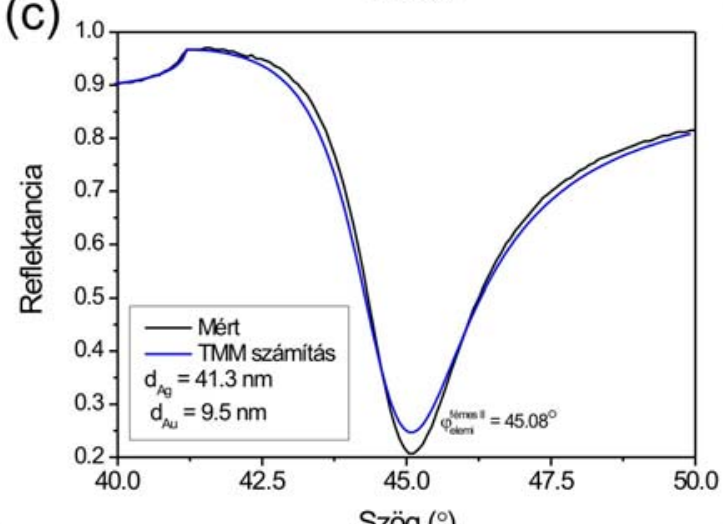

(e)

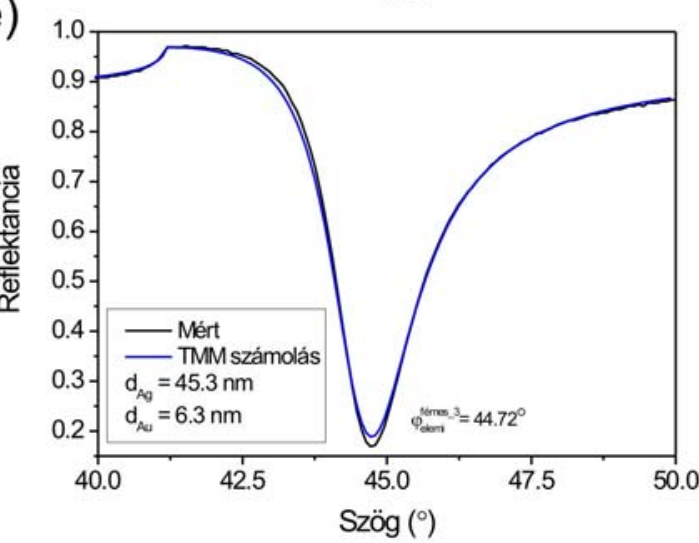

(b)

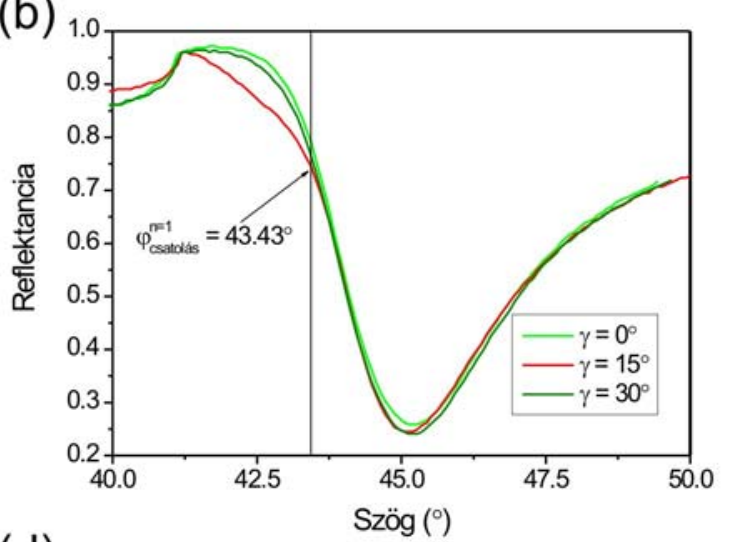

(d)

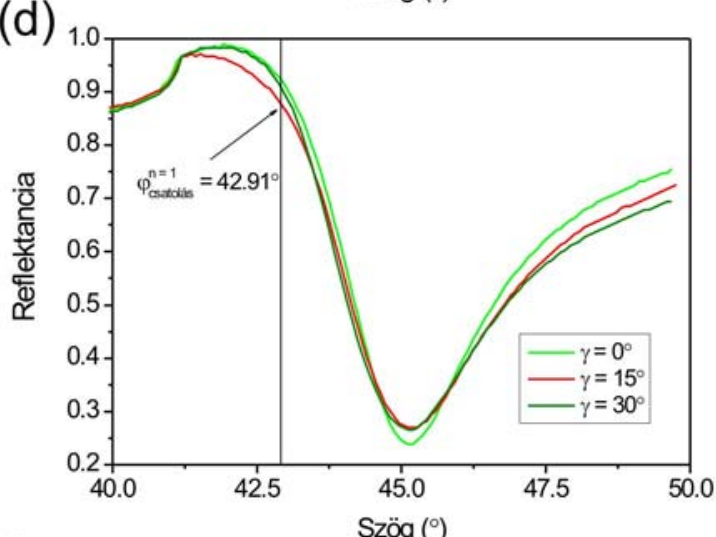

(f)

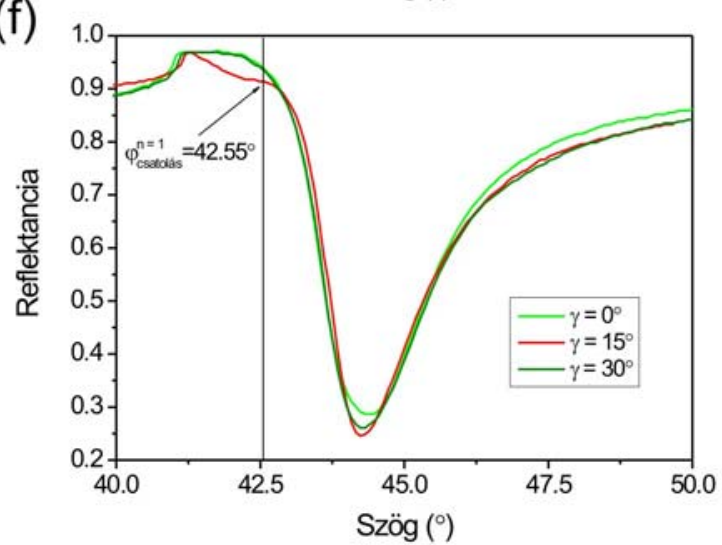

26. ábra. (a), (b) 1-es, (c), (d) 2-es és (e), (f) 3-as fémes minta SPRS mérés eredményei

A bimetál rétegek különböző vastagságpárjainak összehasonlításából levonható a következtetés, hogy az ezüstre párologtatott arany film vastagságával párhuzamosan a 
rezonancia görbe csúcsa erösen kiszélesedik. A TMM számolás nem tökéletes illeszkedése abból is adódik, hogy a filmek dielektromos állandói kissé eltérnek az irodalmi értékektől. A vékony fémrétegek komplex dielektromos állandóinak valós és imaginárius része függ a film minőségétől, tisztaságától, az értékek megváltozása pedig önmagában is okozhatja a csúcsok kiszélesedését. Ezt a változást a számítások során nem vettük figyelembe, mert a különböző rétegkombinációkban más-más az eltérés az irodalmi referenciaértékektől.

Az SPR görbék minimumhelyeinek vizsgálatára mindegyik lézerkezelt mintafelületen három különböző mérés végeztem. A mintafelületeken létrehozott rácsok mélysége az AFM mérések alapján a csatoláshoz szüksége minimális modulációs amplitúdóval összemérhető. A lézerrel létrehozott fémrácsokat rendre $\gamma=0^{\circ}, 15^{\circ}, 30^{\circ}$ azimuthális irányban mértem meg. A lézerkezeléssel előállított rácson való szóródás is kiszélesedést okoz, amely hozzájárul még a fémek dielektromos állandóinak változása. Mindegyik esetben a rezonanciagörbe számottevő kiszélesedése figyelhető meg a kezeletlen felületen mérhető görbékhez képest (26. ábra), melynek oka a fémfilmek szerkezetének lézermelegítés során lejátszódó módosulása. A bimetál rácsok létrejöttét az ezüst-arany határfelületen való ötvözetképződés is kísérheti. TMM számolásaink alapján, mely egy átmeneti ötvözetréteget is figyelembe vesz, ez az átmeneti réteg az eredeti arany film vastagságával összemérhető.

\begin{tabular}{|c|c|c|c|c|c|c|c|c|c|}
\hline Minta & $d_{A g}$ & $d_{A u}$ & $\begin{array}{c}\varphi_{\text {elemi }} \\
\left(^{\circ}\right)\end{array}$ & $\begin{array}{c}\gamma_{\text {csatolás }}^{n=1} \\
\left.\mathbf{(}^{\mathbf{o}}\right)\end{array}$ & $\begin{array}{c}a_{\min }^{n=1} \\
(\mathrm{~nm})\end{array}$ & $\begin{array}{l}a_{\text {attlag }}^{\text {mért }} \\
(\mathrm{nm})\end{array}$ & $\begin{array}{c}\varphi_{\text {csatolás }}^{n=1} \\
\left(^{\mathbf{o}}\right)\end{array}$ & $\begin{array}{c}\varphi_{\text {mért }} \\
\left(^{\circ}\right)\end{array}$ & $\begin{array}{l}\Delta \varphi \\
\left(^{\circ}\right)\end{array}$ \\
\hline Fémrács 1 & 34.9 & 14.8 & 45.6 & 15.81 & 22.46 & $25-30$ & 43.43 & 42.4 & -1.03 \\
\hline Fémrács2 & 41.3 & 9.5 & 45.08 & 15.95 & 22.67 & $25-30$ & 42.91 & 42.25 & -0.66 \\
\hline Fémrács3 & 45.3 & 6.3 & 44.72 & 16.06 & 22.82 & $20-25$ & 42.55 & 42 & -0.55 \\
\hline
\end{tabular}

2. táblázat. SPR mérés és számolás összehasonlítása különböző fémrácsokra. $d_{A g}$ és $d_{A u}$ az egyes minták fémréteg vastagságai, $\varphi_{\text {elemi }}$ a mért rezonanciaminimum a kezeletlen felületen, $\mathrm{n}$ a várható csatolások rendje, $\gamma_{\text {csatolas }}^{n}$ a várható csatolás azimuthális iránya, $a_{\text {min }}^{n}$ az ehhez szükséges minimális modulációs amplitúdó, $\varphi_{c s a t o l a s}^{n=1}$ és $\varphi_{\text {mért }}$ a számolt és mért csatolt minimumhelyek szögértéke valamint a számot minimumhelytől való eltérés $\Delta \varphi$.

A rácsok $\gamma=15^{\circ}=\gamma_{\text {csatolas }}^{n=1}$ szögbe való beforgatása széles oldalszárnyak megjelenéséhez vezetett az SPR görbéken a számolt $\varphi_{\text {csatolas }}^{n=1}$ szögek közelében mindegyik minta esetén. Az oldalszárnyak közepe (azon szakaszé, ahol a reflektancia kisebb, mint a $\gamma=0^{\circ}$ esetben mérhető) a számolt $\varphi_{c s a t o l a s}^{n=1}$ értéktől eltér. Figyelembe véve a sík és mintázott felületeken 
létrehozható plazmonok közötti összefüggést, az elemi és a csatolt minimumhelyek ugyanabba az irányba tolódnak el, amikor a felületkezelés hatására a film optikai vastagsága megváltozik. Bimetál film esetén a rezonancia-minimum visszatolódása mindössze $0.01^{\circ}$ 1 nm-es optikai vastagságváltozás esetén. Az ennél jóval nagyobbnak mért eltolódások arra engednek következtetni, hogy a geometriai változások mellett a fémrétegek optikai tulajdonságai is jelentősen megváltoznak a hosszan tartó lézeres megmunkálás hatására. Mivel a $\varphi_{\text {elemi }}$ szög értékének d vastagság szerinti függvénye kis filmvastagság esetén a legmeredekebb, az eredeti aranyréteg vastagságával fordítottan arányos visszatolódást várnánk. Ennek ellenére a mért visszatolódás-értékeket az eredeti aranyfilm vastagságokkal összehasonlítva azt kapjuk, hogy a fémrács1 mintán mérhető a legnagyobb szögkülönbség érték, ahol a legvastagabb az aranyréteg, míg a legkisebb változás épp a legvékonyabb aranyréteget tartalmazó fémrács3 mintán volt mérhető. Ezek az eredmények azt igazolják, hogy a vastagabb aranyréteg nagyobb szerkezeti és vastagságbeli változást segít elö. A leghangsúlyosabban a fémrács3 mintán jelenik meg a csatolt rezonanciacsúcs, mivel a vékonyabb aranyréteg kisebb kiszélesedést okoz az elemi és a csatolt rezonanciacsúcs esetén is [T1].

Felületi topográfia hatása polimer rácsokon

A vonalas rács esetén az alkalmazott ideális energiasürüség $10.47 \mathrm{~mJ} / \mathrm{cm}^{2}$ volt, megfelelő vastagságú polikarbonát film esetén keskeny félértékszélességü, megfelelő mélységü csatolásnak megfelelő minimumhely mérhető (27. ábra).

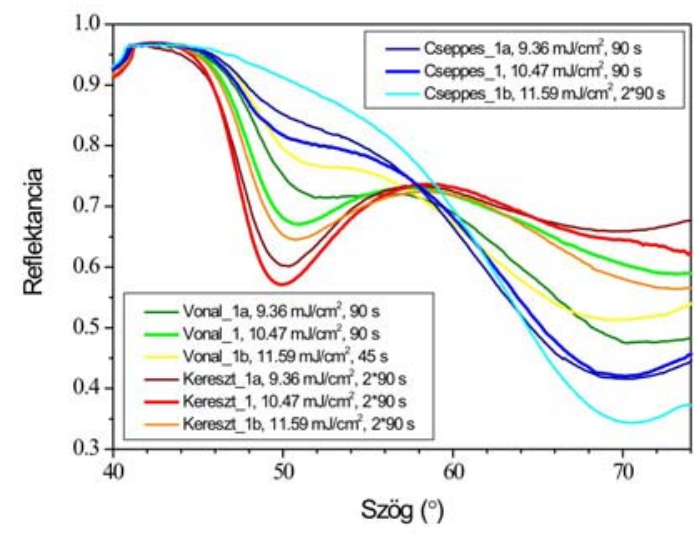

27. ábra. Cseppes, vonalas és kereszt topográfiájú polimer rács SPR mérése

Cseppes rács kialakításához az ideális energiasürüség ennél a PC réteg vastagságnál szintén $10.47 \mathrm{~mJ} / \mathrm{cm}^{2}$ volt, de a csatolásból származó minimumhely kevésbé határozott, mivel ebben az esetben az átlagos filmvastagság csökkenés valamivel kisebb. 
Keresztrácsok esetén figyelhetőek meg a legmélyebb és legkontrasztosabb oldalszárnyak a plazmon rezonanciás görbén, ez a kétirányú megvilágításnak köszönhető. Nagyobb az anyageltávolítás ebben az esetben, illetve felületarányosan kétszeresen jelennek meg azok az anyagváltozások is melyek a mély minimumhelyek kialakulását segítik elő. Ez azt igazolja, hogy két egyszerre jelen lévő rács elősegíti a plazmoncsatolást a rács megfelelő orientációja esetén [T2].

\section{Kolloid gömbök polimer sablonrácson}

A polimer gömbök előzőleg kialakított sablonrácsra való felvitele esetén mindegyik mintakészítési lépés (4. (c) ábra) esetén a plazmon rezonanciás görbéket is mértem különböző azimuthális irányok esetén. A polimer sablonrácsot $\gamma_{\text {polimerrács }}^{1}=13.2^{\circ}$ azimuthális irányba forgatva a rácson létrejövő előre- és hátraszórás a fém-üveg és a PC-levegő határfelületeken gerjeszthető plazmonok hullámszámával egyező plazmonokat hoz létre (28. (a) ábra).
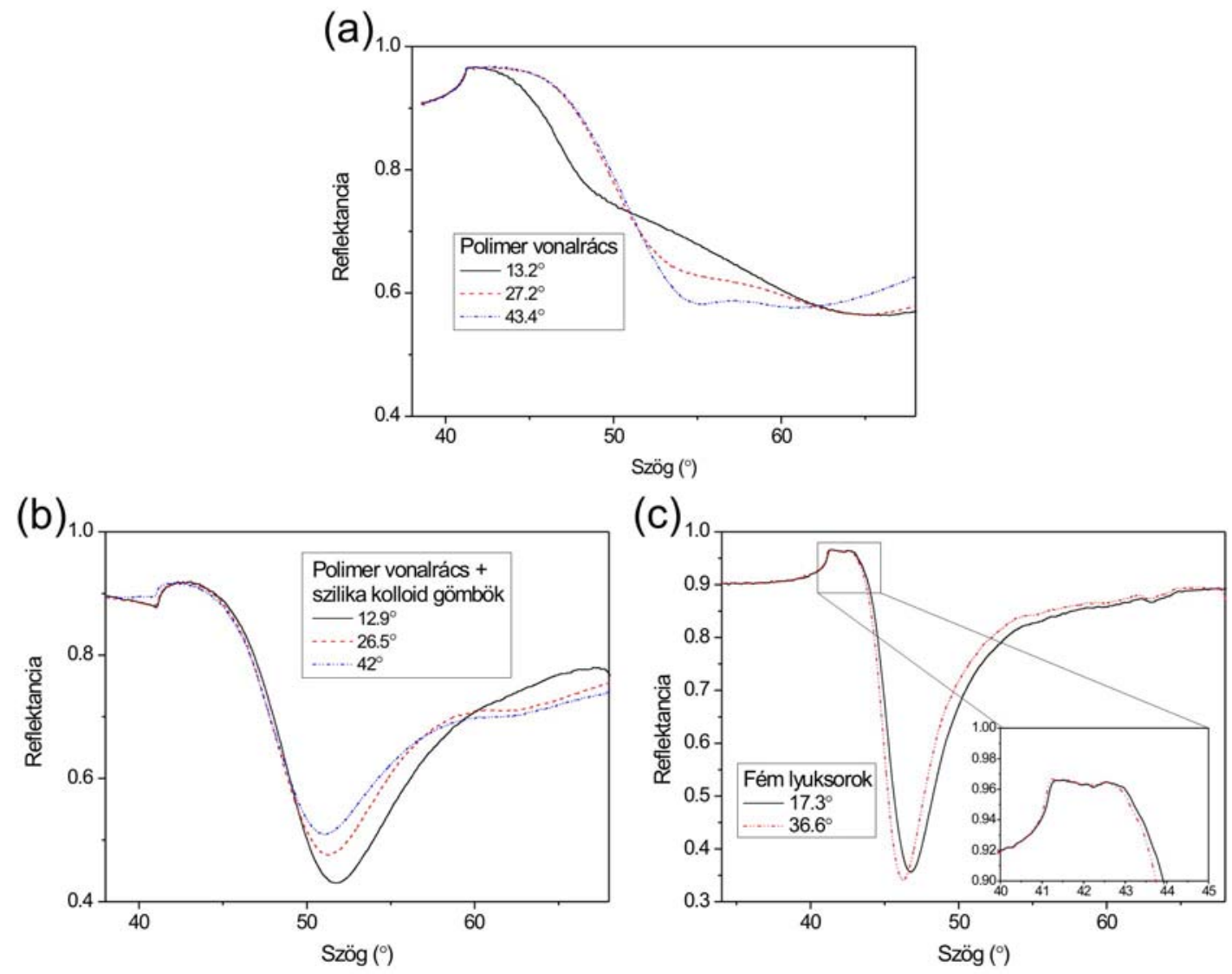

28. ábra. Lyukmintázat létrehozása során az egyes lépések után mérhető plazmon rezonancia görbék 


\begin{tabular}{|c|c|c|c|c|c|c|c|c|}
\hline Minta & $\mathrm{n}$ & $\begin{array}{c}\varphi_{\text {elemi }} \\
\left(^{\circ}\right)\end{array}$ & $\begin{array}{c}\gamma_{\text {csatolás }}^{n} \\
\left(^{\circ}\right)\end{array}$ & $\begin{array}{l}a_{\min }^{n} \\
(\mathrm{~nm})\end{array}$ & $\begin{array}{c}\varphi_{\text {csatolás }}^{n} \\
\left(^{\circ}\right)\end{array}$ & $\begin{array}{c}\varphi_{\text {mért }}^{n} \\
\left(^{\circ}\right)\end{array}$ & $\begin{array}{c}\beta_{\text {szórt }}^{N=1,-} \\
\left(^{\circ}\right)\end{array}$ & $\begin{array}{c}\varphi_{s z o ́ r t}^{N=1,-} \\
\left(^{\circ}\right)\end{array}$ \\
\hline \multirow{4}{*}{ 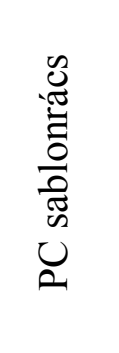 } & 1 & \multirow{4}{*}{66.8} & 13.2 & 12.2 & 63.4 & 49.36 & 26.5 & 66.8 \\
\hline & 2 & & 27.2 & 12.8 & 54.8 & 54.96 & 27.2 & 54.8 \\
\hline & 3 & & 43.4 & 13.9 & 41.9 & 55.12 & 25.9 & 44.4 \\
\hline & 4 & & 66.3 & 17.2 & 21.7 & & 17.6 & 34.0 \\
\hline \multirow{4}{*}{ 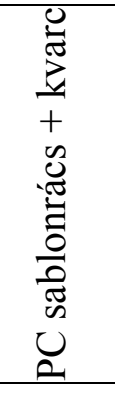 } & 1 & \multirow{4}{*}{70.5} & 12.9 & 10.9 & 66.8 & 51.76 & 25.8 & 70.5 \\
\hline & 2 & & 26.5 & 11.4 & 57.5 & 51.28 & 26.5 & 57.5 \\
\hline & 3 & & 42.0 & 12.4 & 44.5 & 51.12 & 25.3 & 47.0 \\
\hline & 4 & & 63.1 & 14.9 & 25.2 & & 18.5 & 36.8 \\
\hline \multirow{3}{*}{ 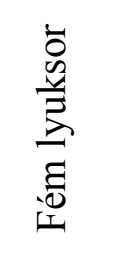 } & 1 & \multirow{3}{*}{44.9} & 17.3 & 22.8 & 42.4 & 42.08 & 34.7 & 44.9 \\
\hline & 2 & & 36.6 & 24.7 & 34.5 & 42.24 & 36.6 & 34.5 \\
\hline & 3 & & 63.3 & 30.8 & 18.5 & & 29.8 & 22.4 \\
\hline \multirow{3}{*}{ 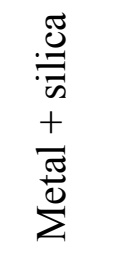 } & 1 & \multirow[t]{3}{*}{45} & 17.3 & 14.7 & 42.5 & 41.04 & 34.6 & 45 \\
\hline & 2 & & 36.5 & 15.9 & 34.6 & 41.04 & 36.5 & 34.6 \\
\hline & 3 & & 63.1 & 19.8 & 18.6 & & 29.8 & 22.5 \\
\hline \multirow{4}{*}{ 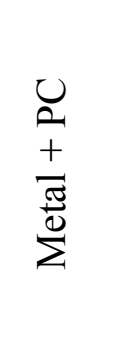 } & 1 & \multirow[t]{4}{*}{62} & 13.8 & 12.7 & 59.0 & 58.72 & 27.6 & 62.0 \\
\hline & 2 & & 28.4 & 13.4 & 50.9 & 46.24 & 28.4 & 50.9 \\
\hline & 3 & & 45.6 & 14.8 & 38.1 & 37.92 & 26.8 & 40.7 \\
\hline & 4 & & 72.3 & 19.2 & 15.6 & & 14.8 & 29.9 \\
\hline
\end{tabular}

3. táblázat. SPR mérés és számolás összehasonlítása különböző esetekben. $\varphi_{\text {elemi }}$ a mért rezonancia-minimum a kezeletlen felületen, $\mathrm{n}$ a várható csatolások rendje, $\gamma_{\text {csatolas }}^{n}$ a várható csatolás azimuthális iránya, $a_{\min }^{n}$ az ehhez szükséges minimális modulációs amplitúdó, $\varphi_{\text {csatolas }}^{n}$ és $\varphi_{\text {mért }}^{n}$ a számolt és mért csatolt minimumhelyek szögértéke (félkövér betűvel kiemelve a kísérletben elérhető számolt értékek) valamint az $\mathrm{N}=1$ visszaszórásnak megfelelő

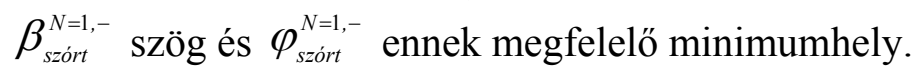


Ennél az azimuthális szögnél csak kis kiszélesedés figyelhető meg, hiszen a $\varphi_{\text {polimerrács }}^{1}=63.4^{\circ}$ az elemi csúcshoz egészen közel található. A $\gamma_{\text {polimerrács }}^{2}=27.2^{\circ}$ azimuthális irány esetén kettőződés tapasztalható és egy minimumhely megjelenése körvonalazódik a $\varphi_{\text {polimerrács }}^{2}=54.8^{\circ}$ várható poláris szög környékén. A $\gamma_{\text {polimerrács }}^{3}=43.4^{\circ}$ iránynál megjelenő mélyebb minimumhely a $N=1$ rendű szórás miatt fellépő levegőoldali plazmon intenzitásnövekedésével magyarázható.

Kvarc gömbökkel bevont sablonrács esetén a levegőoldali plazmon visszaszórás miatt mély rezonancia-mimimum erős csatolási hatásfokra utal, valamint arra, hogy nagy felülethányad borított a kvarcot és polikarbonátot tartalmazó rezonáns réteggel (. (b) ábra).

A lézeres megmunkálás után kapott lyuksorok plazmon rezonanciás mérése $\gamma_{\text {lyuksor }}^{1}=17.3^{\circ}$ irányban egy gyenge minimumhelyet mutat $\varphi_{\text {lyuksor }}^{1}=42.4^{\circ}$ poláris szögnél, az elsőrendü csatolásnak megfelelően. A minimumhely kis mélysége arra utal, hogy kis felületrészt borít megfelelő rezonáns bimetál réteg. A rácsok és lyukak mélysége nem volt elég mély ahhoz, hogy mélyebb minimumhely legyen megfigyelhető a $\gamma_{\text {lyuksor }}^{2}=36.6^{\circ}$ azimuthális irány esetén, ahol a másodrendű csatolás és elsőrendű szórás együttes jelenléte miatt erösebb hatást vártunk. Ezek a csatolási szögek nem közelítik meg azt a tartományt, ahol a bimetál-levegő és bimetál-üveg határfelületen megjelenő plazmonok keresztcsatolása létrejöhet, így a mért minimumhelyek csak a rácscsatolásból származnak (28. (c) ábra). A számolások és mérések eredményeit a 3. táblázatban foglalom össze, a mérés során megjelenő számolt szögértékeket félkövér szedéssel emeltem ki [T4].

Fém lyuksor bevonása kolloid részecskékkel és polikarbonát filmmel

A létrehozott lyukmintázat kvarc gömbökkel való visszavonása csak részben borította be a felületet (4. (e) ábra). Ezt a multiréteget $\gamma_{k \text { var c, bimetal }}^{1}=17.3^{\circ}$ azimuthális irányba forgatva kis félértékszélességü csatolásból származó minimumhely jelenik meg a rácscsatolásnak megfelelően számolt $\varphi_{k \text { varc, bimetál }}^{1}=42.5^{\circ}$ szög közelében. Hasonló minimumhely jelenik meg a másodrendű csatolásnak és elsőrendű szórásnak megfelelő $\gamma_{k \text { var c, bimetal }}^{2}=36.5^{\circ}$ irány esetén is. A csatolás hatásfoka valamivel magasabb, mint a sima bimetál lyuksor esetén, mivel a csatoláshoz kisebb modulációs amplitúdó szükséges dielektrikum réteggel való bevonás esetén (29. (a) ábra). 
(a)

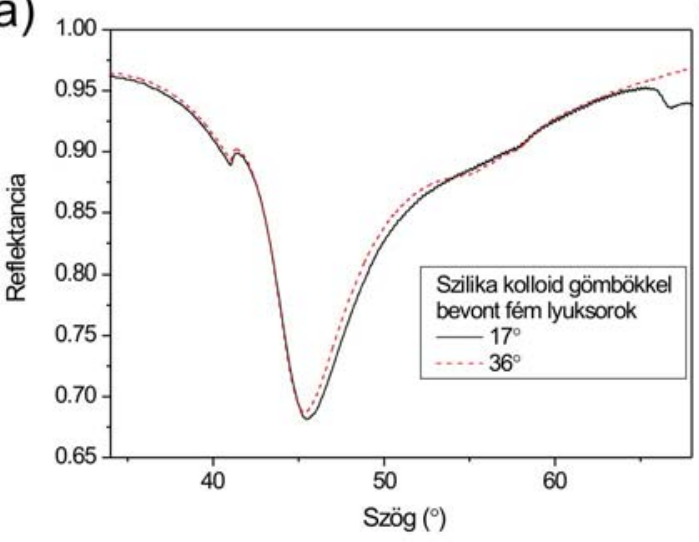

(b)

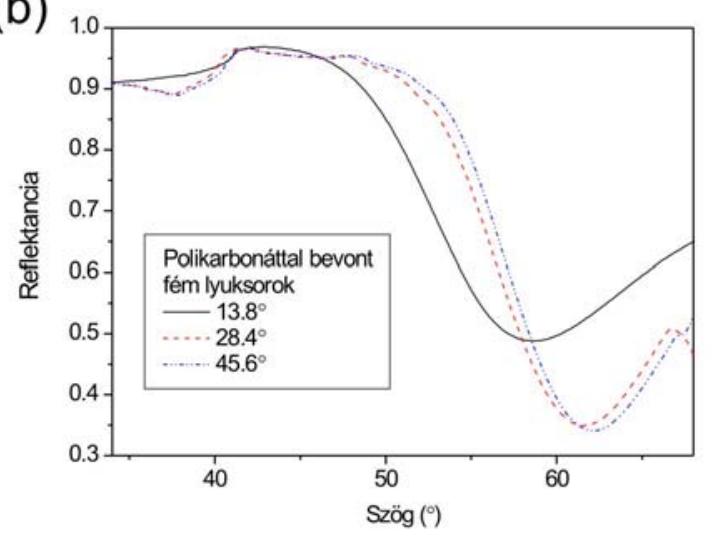

29. ábra. Fém lyuksor visszavonása (a) Stöber-kvarc kolloid gömbökkel és (b) polikarbonát vékonyréteggel

A fém lyuksorok vékony polimer filmmel való visszavonása (4. (f) ábra) a rezonanciagörbe kiszélesedését okozza . A $\gamma_{P C \text {, bimetal }}^{1}=13.8^{\circ}$ azimuthális irányban az elsőrendü csatolás az elemi minimumhelyhez közeli csúcsot eredményez, ami a kiszélesedést okozza. A szintén fellépő másodrendű csatolás és elsőrendű szórás együttesen a várható $\varphi_{P C, \text { bimetal }}^{2}=50.9^{\circ}$ közelében jelenik meg $\gamma_{P C \text {, bimetal }}^{2}=28.4^{\circ}$ azimuthális irányba való forgatás esetén. Ez a minimumhely kisebb mélységü az eredeti polimer rácson mérhető minimumhelyhez képest, a kis hatásfokú rács-csatolás oka a rácsként viselkedő fémpolikarbonát határfelület kis modulációs amplitúdója. A számolások és mérések eredményeit a 3. táblázatban fogalom össze, a mérés során megjelenő számolt szögértékeket ez esetben is félkövér szedéssel emeltem ki [T4].

\section{Kolloidgömb litográfia spektrális hatása}

Fém kolloid gömbök monorétegének homogén és KGIM módszerrel történő kivilágításával nyert mintázatok spektrális hatásának modellezésekor a létrehozható mintázatot egyenletesnek tekintettem méret, alak, és egymás közötti távolságok szempontjából. Ideális kísérleti körülmények között ezek a feltételek teljesülnek, ha a monoréteg és az interferencia-mintázat megfelelő, köztük a szinkronizáció és az alkalmazott energiasűrüség jól szabályozott.

Az 532 nm-es hullámhosszú s-polarizált fénnyel kivilágított, d=90 nm átmérőjü ritkásan elhelyezett gömbökkel létrehozható (20. (a) és (b) ábrák) lyukpárok (kitöltött jelzés 30. ábrán) és a polarizálatlan fénnyel előállítható hengeres lyukak (kitöltetlen jelzés 30. ábrán) spektrális hatását vizsgáltam különböző kivilágítással nyerhető mintázatok esetén. Referenciamintázatként homogén nyalábbal kivilágított, a klasszikus kolloid litográfiával létrehozható 
hatszöges elrendezésű lyukakból és lyukpárokból álló mintázatot használtam. Ezekhez a referencia-mintázatokhoz hasonlítom a KGMIK módszerrel létrehozható négyszöges elrendezésű, hengeres lyukakból vagy lyukpárokból álló mintázatok hatását. Minden esetben a bemutatott adatokat a következő korrekcióval mutatom be: a lyukmintázatot tartalmazó film jeléből kivontam a megfelelő homogén film adta jelet, valamint a kapott értéket lyukfelület egységcella-felület aránnyal normalizáltam. Az egyes mintázatok esetén használt egységcellát a 30. (a) és (b) ábrán látható piros téglalapok szemléltetik.

(a)

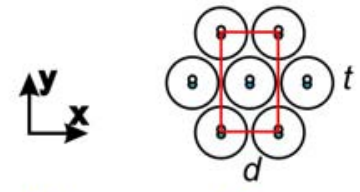

(1) $4.4 \times 10^{4}$

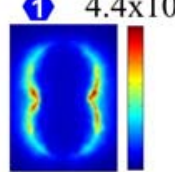

(c)

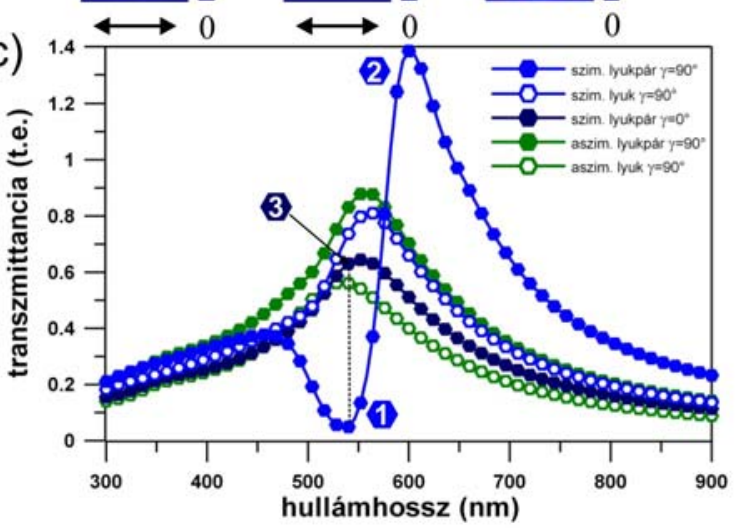

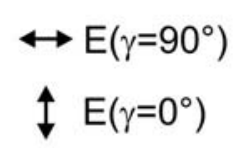

(b)
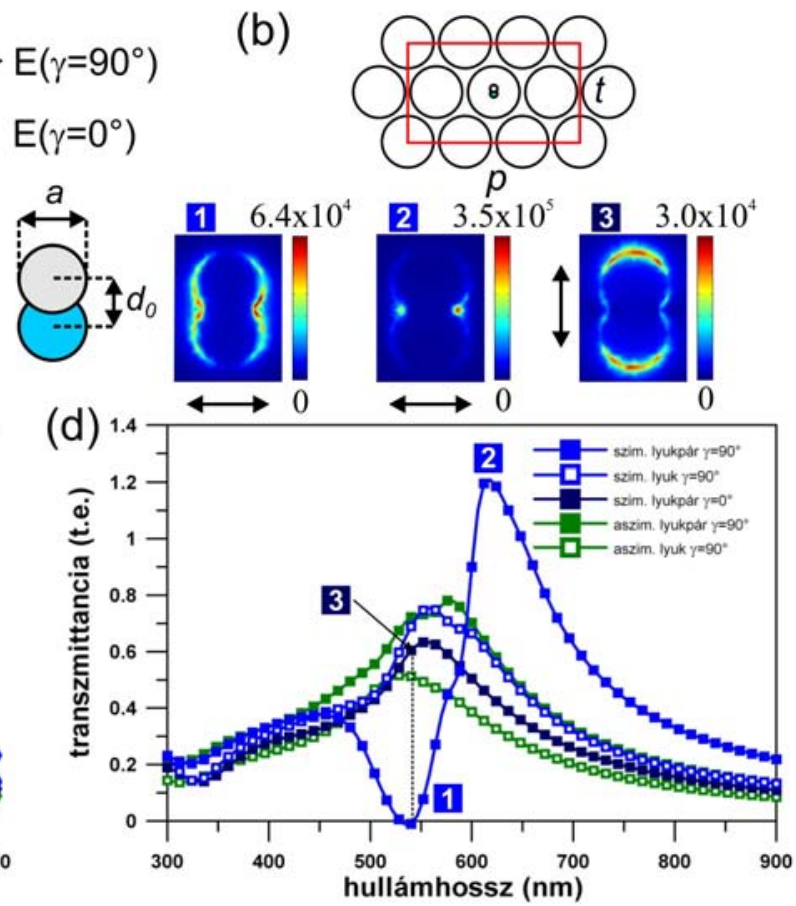

30. ábra. A modellezésnél használt egységcellák sematikus rajza (a) hatszöges és (b) négyszöges elrendezés esetén, és a normalizált elektromos tér lyukpárokon szimmetrikus

közeg esetén a $\gamma=90^{\circ}$ eset transzmittancia minimumainál $(534 \mathrm{~nm}$ és $540 \mathrm{~nm}$ ) és maximumainál $(600 \mathrm{~nm}$ és $618 \mathrm{~nm})$, valamint $\gamma=0^{\circ}$ irány $534 \mathrm{~nm}$ és $540 \mathrm{~nm}$ hullámhosszakkal. (c), (d) Lyukméretre normalizált és korrigált transzmittancia spektrum $45 \mathrm{~nm}$ vastag arany filmen különböző (c) hatszöges és (d) négyszöges lyukmintázatok esetén.

P-polarizált fénnyel való kivilágítást mutatunk be, ahol a beesési sík párhuzamos az $\mathrm{x}$ tengellyel $\left(\gamma=90^{\circ}\right)$ lyukak (kitöltetlen jelzés) és lyukpárok (kitöltött jelzés) szimmetrikus (kék) és antiszimmetrikus (zöld) közegben. Szimmetrikus közegben lévő lyukpárokat $\gamma=0^{\circ}$ irányban is számoltuk (sötétkék kitöltött jelzéssel).

A 30. (a) ábrán látható $d=100 \mathrm{~nm}$ és $t=\sqrt{3} \cdot d$ távolságok a HCP elrendezésben lévő gömbtávolságoknak felelnek meg (20. (a) ábra), míg a 30. (b) ábráról leolvasható $p=300 \mathrm{~nm}$ és $t=\sqrt{3} \cdot d$ távolságok a II-es geometria egységcellájának méretei (20. (b) ábra). A hengeres lyukak (szürke kitöltés 30. ábrán) átmérője $a=12.8 \mathrm{~nm}$ a számolt közeltér intenzitáseloszlás félértékszélességnek megfelelően, míg az egymást fedő hengerek középpontjainak távolsága lyukpárok (szürke és világoskék kitöltés) esetén $d_{0}=8.9 \mathrm{~nm}$. 
A transzmittancia-értékeket minden lyukmintázat esetén előbb aszimmetrikus környezet esetén számoltam ki, mely esetben a lyukakban és a lyukakat tartalmazó film felett levegő található, majd ugyanezen számolásokat megismételtem szimmetrikus közegre is, amikor a mintázatot arany vékonyréteget NBK7 veszi körül és ez tölti ki a lyukakat is (30. (c) és (d) ábrán zöld illetve kék, (e) és (f) ábrán narancs illetve vörös). A spektrális számítást olyan elrendezésben végeztem, ahol a p polarizációjú $\mathbf{E}$ tér rezgési iránya a lyukpárok hossztengelyére merőleges $\left(\gamma=90^{\circ}\right.$ azimuthális irány), majd szimmetrikus közegben lyukpárok esetén azt az esetet is, amikor a rezgési irány a lyukpárok hossztengelyével párhuzamos $\left(\gamma=0^{\circ}\right.$ azimuthális irány, 30. (c) és (d) ábrán sötétkék, (e) és (f) ábrán bordó színnel jelölv(e).

Az egyes lyukak kis átméröje ellenére transzmittancia-csúcsok jelennek meg az arany rezonancia-hullámhossza közelében minden esetben (30. (c)-(f) ábrák). A maximumok helyzete a mintázat geometriájától és a közeg anyagától függ [81]. A szélsőértékhelyek minden esetben a négyszöges mintázat esetén a vörös irányába tolódnak el a hatszöges elrendezéshez képest adott lyukalakra és közegre a mintázat rezonanciájának periódusfüggése miatt [82], ugyanakkor a lyukak alakjának a spektrumgörbékre való erős hatása is megfigyelhető (30. 5(c)-(f) ábra). A transzmittancia-karakterisztikák azt mutatják, hogy a KGMIK módszerből természetszerüleg fakadó lyukpárok egyedi spektrális tulajdonságokkal rendelkeznek. A lyukpárok a spektrumbeli szélsőértékhelyek nagyobb hullámhosszaknál megjelenő hangsúlyosabb transzmittancia erősítést okoznak, amikor az E-tér rezgése hossztengelyükre merőleges, azaz $\gamma=90^{\circ}$ azimuthális irány esetén (30. ábra kitöltött és kitöltetlen jelölések összehasonlítása alapján). Hasonló E-térre való szelektivitás megfigyelhető ellipszis alakú lyukak esetén [83, 84].

A normalizált transzmittanciaértékek mindkét esetben nagyobbak egynél, de csak akkor, ha lyukpárok alkotják a mintázatot és ezeket hossztengelyükre merőleges rezgési síkú E-térrel rendelkező fénnyel világítjuk ki szimmetrikus közegben (30. ábra (c) és (d)). Érdekes módon minimumhelyek (534 nm és $540 \mathrm{~nm}$ ) jelennek meg a transzmittancia görbéken a határozott maximumok (600 nm és $618 \mathrm{~nm}$ ) előtt mindkét geometria esetén.

A határozott transzmittancia maximumok olyan spektrális tartományban jelennek meg, ahol a plazmon-hullámhosszak nagyobbak a karakterisztikus periódusoknál. A transzmittancia maximumok előretolódása a Rayleigh-feltétel teljesülésének megfelelő hullámhosszakhoz képest a lyukmintázatokon való gerjesztés során fellépő fázisváltozásokkal magyarázható $[85,86]$. 
Ha az elektromos tér rezgési iránya párhuzamos a lyukpár hossztengelyével $\left(\gamma=0^{\circ}\right)$, nem figyelhetők meg minimumhelyek, csak egyetlen maximum jelenik meg. A $\gamma=90^{\circ}$ esethez tartozó minimumhelyeknél ( 1-es és 3-as számokkal jelölve a 30(c) és (d) ábrákon) a transzmittancia értékeket összehasonítva a két különböző polarizációra megállapítható, hogy nagyobb polarizáció-érzékenység érhető el négyszöges mintázat használatával. A lyukpárokon szimmetrikus közegben $\gamma=90^{\circ}$ fokban mért normalizált transzmittancia minimum értékek azt mutatják, hogy mindkét mintázat esetén a transzmittancia a folytonos film esetén elérhető értékek közelében van. A közeltérbeli metszetek számottevő E-térerősség növekményt mutatnak ezeknél a minimumhelyeknél lyukpárok esetén (30.(a) és (b) ábra első képek).

Maximumok esetén azonban a közeltérbeli intenzitás jóval nagyobb a megerösödött transzmittanciának megfelelően (30(a) és (b) ábra középső képek). Ennek oka a külső tér erösödése a hosszanti kiterjedésű lyukpárokon megjelenő dipólus momentum miatt, ha a tér rezgése merőleges ezek hossztengelyére. A $\gamma=90^{\circ}$ eset transzmittancia minimumhelyeinek megfelelő hullámhosszaknál tapasztalhatónál a $\gamma=0^{\circ}$ esetben a közeltérbeli intenzitás jelentősen kisebb (30(a) és (b) ábra utolsó képek). Ez a kisebb érték annak köszönhető, hogy a térnövekmény kisebb, ha a lyukpárok hossztengelyével az elektromos tér rezgési iránya párhuzamos [83].

Általános jellemzője a hatszöges és négyszöges mintázatoknak is, hogy a transzmittancia maximalizálásához előnyös lyukpárokat alkalmaz lyukak helyett és szimmetrikus közeget aszimmetrikus helyett. Ezen felül ezen megfigyelések igazolják KGMIK módszerrel előállított nanoméretű lyukpárok segítségével az elektromágneses tér terjedésben megjelenő plazmonikus jelenségeknek köszönhetően jobb polarizációérzékenység is elérhető [T5]. 


\subsection{Plazmonikus struktúrák alkalmazása a biodetektálás érzékenységének növelésére}

Sztreptavidin detektálása fémrácson

Sztreptavidin fehérje detektálására a legvékonyabb arany réteget tartalmazó fémrács3a jelű mintát választottam, amely a megmunkálást segítő aranyréteg és a nem túlságosan kiszélesedett rezonanciagörbe előnyeit egyesíti.

(a) Topográfia

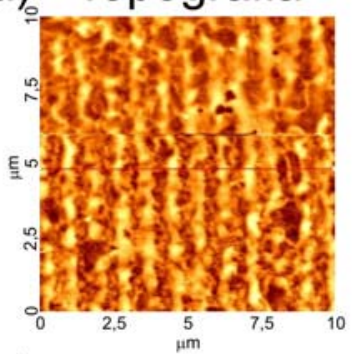

(c)

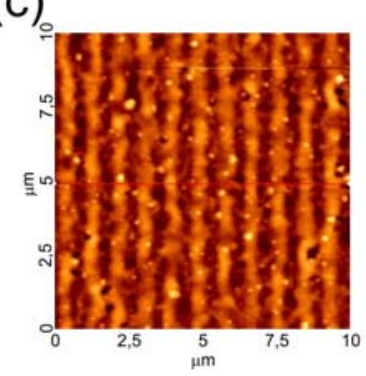

(e)

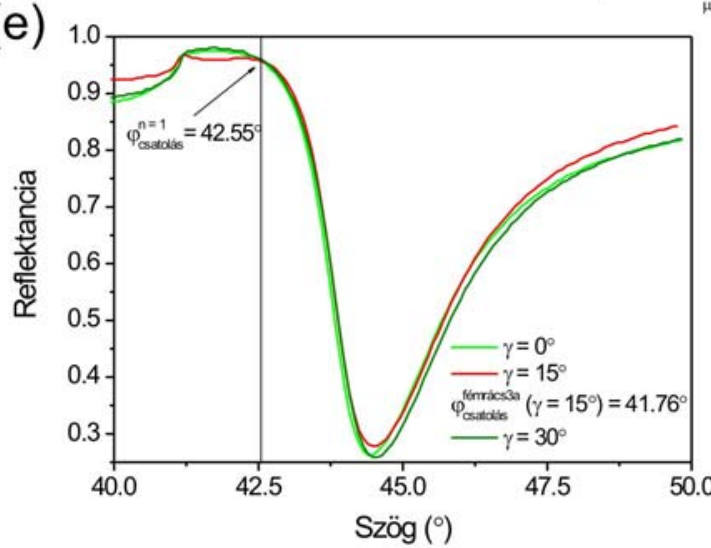

(b)

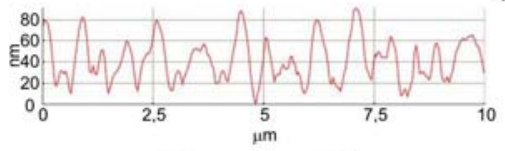

fémrács3a
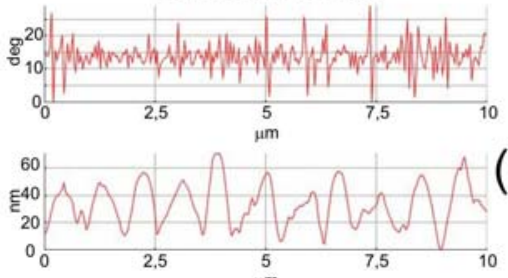

fémrács $3 a$

+ sztreptavidin

$\mathrm{c}=1 \mu \mathrm{g} / \mathrm{ml}$

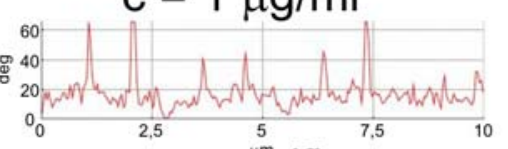

(f)

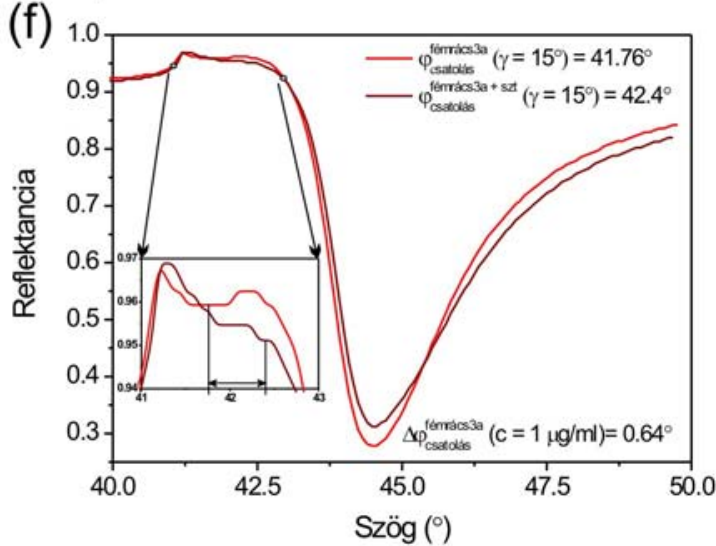

31. ábra. 3a-as fémes mintán sztreptavidin hatása (a) AFM topográfia fehérje előtt (b) fázis fehérje elött (c) topográfia fehérjefelvitel után (d) fázis fehérjefelvitel után (e) plazmonikus rezonancia-görbék sztreptavidin felvitele elött és (d) sztreptavidin hatására.

Fémrács3a minta esetén az $F_{\text {átl }}=39.5 \mathrm{~J} / \mathrm{cm}^{2}$ energiasürüség mellett alkalmazott lövésszám $\mathrm{N}=200$ volt, ami mélyebb és rendezettebb rács létrehozását tette lehetővé (12. (c) és 31. (a) ábra, 2. és 4. táblázat) a topográfiai összehasonlítás esetén alkalmazott $\mathrm{N}=100$ lövésszámhoz képest. A rácsot $\gamma=15^{\circ}=\gamma_{\text {csatolas }}^{n=1}$ azimuthális irányba forgatva a csatolásnak 
megfelelő minimumhely megjelenése volt kimutatható (31(e) ábra). A bimetál rács esetén fehérjefelvitel elött és után számolt és mért eredményeket a 4. táblázatba foglaltam össze.

A mintafelületre kis mennyiségü sztreptavidin tapadt ki a $c_{1}^{s z t}=1 \mu \mathrm{g} / \mathrm{ml}$ koncentrációjú oldatba való merítés után, ez TM AFM és plazmon rezonanciás spektroszkópia segítségével kimutatható volt. Amint az AFM fázis képek mutatják (31(b) és (d) ábrák), a fehérje a rácsok völgyeibe tapadt ki, a fázisképeken megfigyelhető kontrasztot jelentősen megnövelve. A mintafelületen lézerrel létrehozott morfológiai változás, azaz a fém lyukak és szemcsék megjelenése a sztreptavidin molekulák rácsvölgyekbe való kiülését elősegítette (31. (a) és (c) ábrák). A rácscsatolás miatt megjelenő rezonanciacsúcs fehérjefelvitel hatására történt elmozdulása $\Delta \varphi_{\text {csatolalas }}^{\text {bimetal }}\left(c_{1}^{s z t}=1 \mu \mathrm{g} / \mathrm{ml}\right) \geq 0.64^{\circ}$ volt (31(f) ábra).

\begin{tabular}{|c|c|c|c|c|c|c|c|}
\hline Minta & $\varphi_{\text {elemi }}$ & $\gamma_{\text {csatolas }}^{n=1}$ & $a_{\text {csatolas }}^{n=1}$ & $a_{\text {attag }}^{\text {mér }}$ & $\varphi_{\text {csatolas }}^{n=1}$ & $\varphi_{\text {csatolas }}^{\text {mért }}$ & $\Delta \varphi$ \\
$\left({ }^{\circ}\right)$ & $\left({ }^{\circ}\right)$ & $(\mathrm{nm})$ & $(\mathrm{nm})$ & $\left(^{\mathrm{o}}\right)$ & $\left(^{\circ}\right)$ & $\left(^{\mathrm{o}}\right)$ \\
\hline Fémrács3a & 44.72 & 16.06 & 22.82 & $25-30$ & 42.55 & 41.76 & -0.79 \\
\hline Fémrács3a + szt. & 44.72 & 16.06 & 22.82 & $<25-30$ & 42.55 & 42.4 & 0.64 \\
\hline
\end{tabular}

4. táblázat. SPR mérés és számolás összehasonlítása különböző esetekben, ahol $\varphi_{\text {elemi }}$ a mért rezonancia-minimum a kezeletlen felületen, $\mathrm{n}$ a várható csatolások rendje, $\gamma_{\text {csatolas }}^{n}$ a várható csatolás azimuthális iránya, $a_{\text {min }}^{n}$ az ehhez szükséges minimális modulációs amplitúdó, $\varphi_{c s a t o l a s}^{n}$ és $\varphi_{\text {mért }}^{n}$ a számolt és mért minimumhelyek szögértéke (félkövér betüvel kiemelve a kísérlet során elérhető számolt értékek) valamint az $N=1$ visszaszórásnak megfelelő $\beta_{\text {szór }}^{N=1,-}$ szög és $\varphi_{\text {szzort }}^{N=1,-}$ ennek megfelelő minimumhely.

Megfelelő intenzitással és lövésszámmal fémfilm esetén a filmvastagsággal összemérhető mélységü rács alakítható ki a felületen. Az arany jelenléte elősegíti megfelelő mélységü és rendezettségü rácsok létrehozását, de a rétegvastagsággal arányosan a plazmon rezonancia görbe kiszélesedését okozza. Megfelelő rétegvastagság választásával az előnyök és hátrányok kiegyenlíthetők, nagy hatásfokú rácscsatolást lehetővé tevő mély arannyal borított rácsfelület állítható elő. A bimetál rácsok kis mennyiségü sztreptavidin kimutatására nagy érzékenységü detektorként használhatók AFM és plazmon rezonancia spektroszkópia módszerének alkalmazásával [T1]. 


\section{Sztreptavidin detektálása polikarbonát rácson}

A fémrácsokhoz hasonlóan polimer vonalas rácson a többlépéses fehérje bevonás a modulációs mélység kis csökkenésével és a fáziskontraszt megnövekedésével jár. Az AFM képeken látható világos foltok sürüsége és eloszlása azt mutatja, hogy a fázisjelben tapasztalható erősítésbeli különbség az egyes fehérjekeverékek esetén fellépő adhéziós folyamatok következménye. Az 1-es minta topográfia és fázisképe azt mutatja, hogy a sürün elhelyezkedő peptid molekulák a rácsvölgyekben tapadnak ki (32. (c) és (d) ábra). A felvitt keverékben található biotin-molekulákhoz jelöletlen sztreptavidin kikötése után a 2-es mintán egy vastagabb réteg képződése figyelhető meg kis szigetek képződése mellett (32. (e) és (f) ábra). Kevésbé folytonos másodlagos rétegképződés, de nagyobb számú és kevésbé elkülönült szigetek képződnek FNG-sztreptavidin konjugátum felvitele esetén (32. (g) és (h) ábra). Ezek a szigetek nem tökéletesen a rácsvölgyekben helyezkednek el, hanem eloszlásuk véletlenszerübb és az előzőleg felvitt peptid-biotinilált peptid réteghez való kötődés is kevésbé erősnek tünik. Ezt az egy4 nm-es arany részecskéből és egy sztreptavidin molekulából álló konjugátum polaritása magyarázhatja. CG-sztreptavidin esetén a rácsvölgyekbe rendezetten elhelyezkedő sürü szigetek alkotják a másodlagos réteget, ezt a 10 nm méretü körülbelül 100 sztreptavidin molekulával borított összetett részecskék FNGsztreptavidintől eltérő felületi kémiai tulajdonságai okozzák.

A számolt és mért csatolásból származó minimumhelyeket összehasonlítva (Függelék 1. táblázat) megállapítható, hogy az egymást követő fehérjefelvitel a csatolásból adódó minimumhely fokozatos eltolódását vonja maga után. A számolások során a fehérjékre a 2.05-i·0.01 komplex dielektromos állandót alkalmaztam [63]. TMM számolás segítségével kiszámoltam az 1-es mintán mért $\Delta \varphi_{\text {csatolas }}^{1-e s+a+p+b}=2.48^{\circ}$ eltolódáshoz tartozó átlagos fehérjevastagságot. 
(a) Topográfia

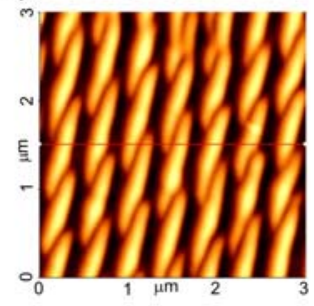

(c)

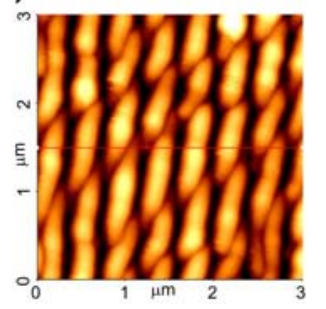

(e)

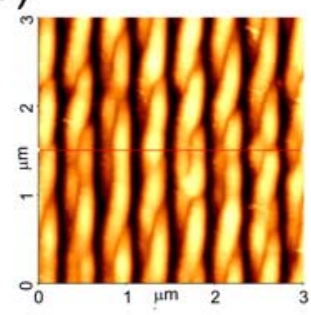

(g)

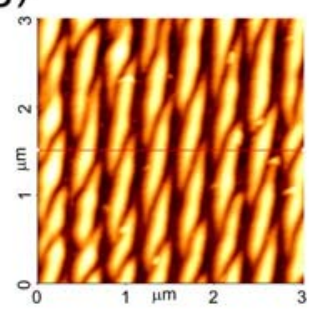

(i)

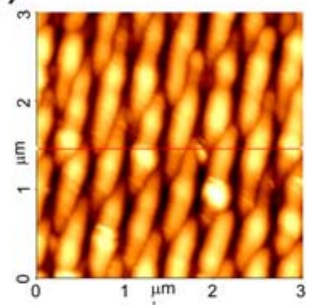

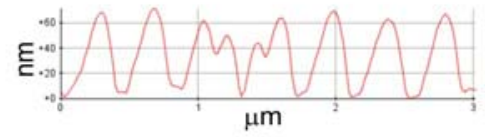

1-es minta
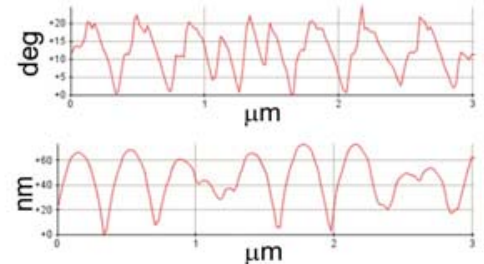

1-es minta + peptid + biotinilált peptid
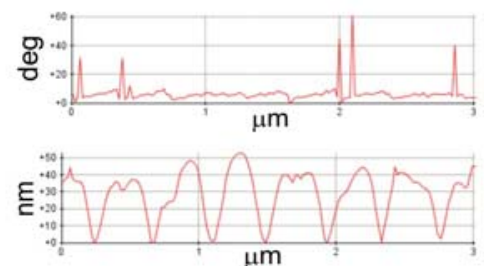

2-es minta + peptid + biotinilált peptid + szterptavidin
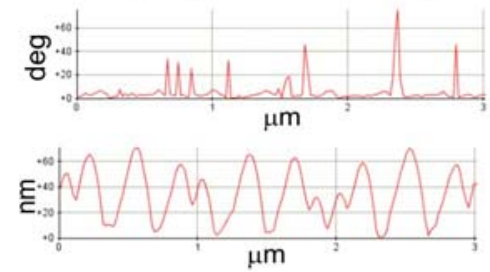

3-as minta + peptid + biotinilált peptid + FNG-sztreptavidin
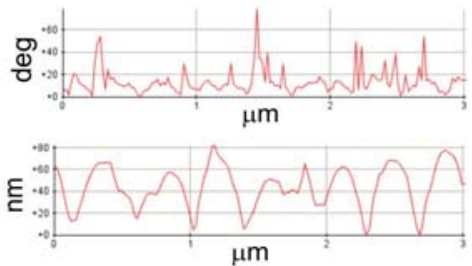

4-es minta + peptid + biotinilált peptid + CG-sztreptavidin

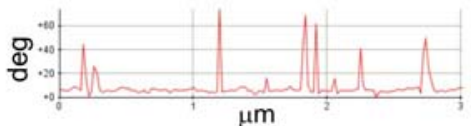

(b) Fázis

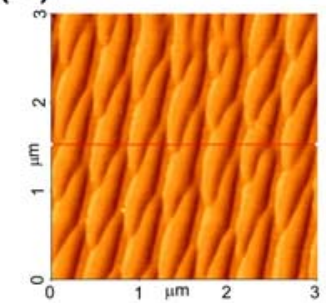

(d)

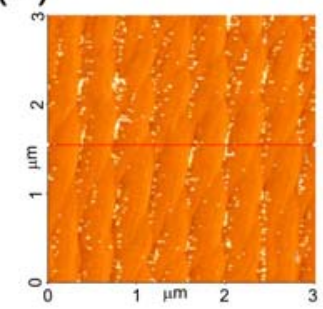

(f)

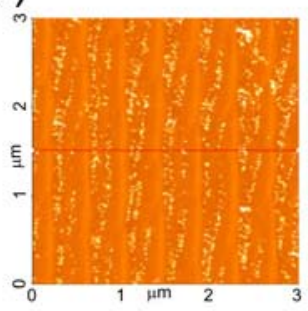

(h)

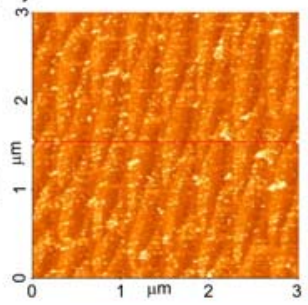

(j)

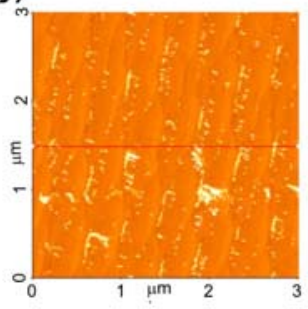

32. ábra. AFM topográfia és fázis képek (a)-(b) üres vonalrácsról 1-es mintán; (c)-(d) peptid-biotinilált peptid keverékével bevont 1-es mintán; (e)-(f) sztreptavidin kikötés 2-es mintára; (g)-(h) FNG-sztreptavidin a 3-as mintán és (i)-(j) CG-sztreptavidin $10 \mathrm{~nm}$ átméröjü arany kolloidrészecskékkel a 4-es mintán.

A továbbiakban feltételeztem, hogy ugyanezen $\Delta d_{p+b p}=6.06 \mathrm{~nm}$ vastagságú peptidréteg tapad ki a többi minta esetén is. A peptid és jelöletlen sztreptavidin kikötése 
összesen a $\Delta \varphi_{\text {csatolas }}^{2-e s \text { minta+szt }}=3.04^{\circ}$ eltolódást okozott a 2-es mintán, ami egy további $\Delta d_{s z t}=1.32 \mathrm{~nm}$ átlagvastagságú sztreptavidin rétegnek felel meg a peptid és biotinilált peptid alkotta fehérjerétegen felül.
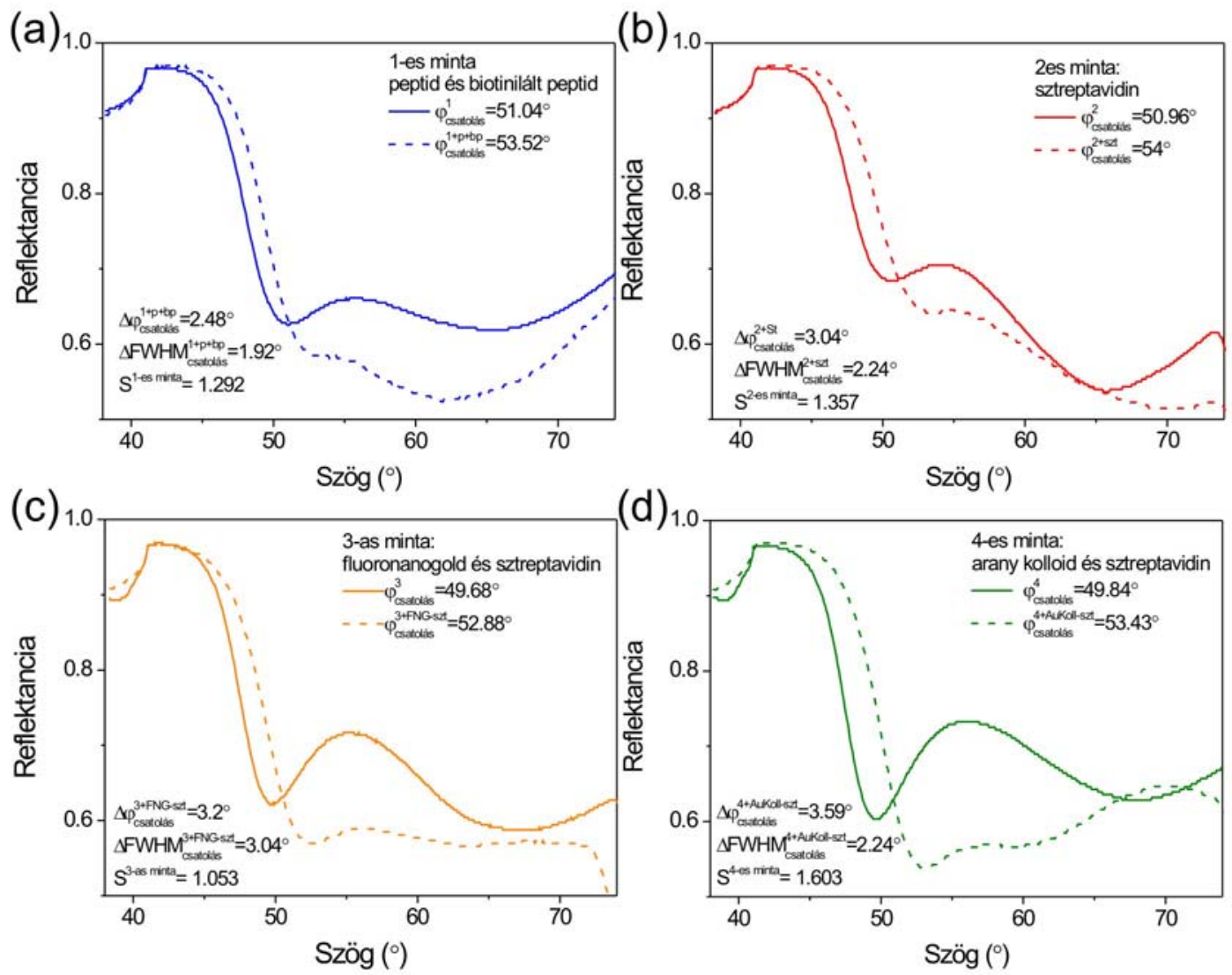

33. ábra. Kettős csúcsú plazmonrezonanciás görbék fehérjefelvitel elött és után (folytonos és szaggatott vonalak) az egyes polimer vonalrácsokon másodlagos minimumhelyek eltolódását a következő fehérjebevonat kombinációk okozzák: (a) peptid-biotinilált peptid réteg 1-es minta esetén, (b) egy hasonló rétegre további sztreptavidin felvitel 2-es minta esetén, (c)

FNG-sztreptavidin 3-as mintán és (d) CG-sztreptavidin $10 \mathrm{~nm}$ átméröjü arany kolloidrészecskékkel a 4-es mintán.

FNG-sztreptavidin és CG-sztreptavidin esetén az erös biotin-sztreptavidin kötés miatt ugyanakkora sztreptavidin mennyiség tapad ki, így ugyanaz az átlagvastagság feltételezhető 3-as és 4-es minták esetén is. Az arany-sztreptavidin vastagságarányt a kitapadt arannyal jelölt biomolekula-rétegekben az alábbi összefüggéssel határoztam meg:

$$
\frac{\Delta d_{A u}}{\Delta d_{s z t}}=\frac{\Delta m_{A u}}{\Delta m_{s z t}} \frac{\rho_{s z t}}{\rho_{A u}}
$$

ahol $\rho_{s z S t}=1000 \mathrm{~kg} / \mathrm{m}^{3}$ és $\rho_{A u}=19300 \mathrm{~kg} / \mathrm{m}^{3}$ a sztreptavidin és az arany sürüsége; $\Delta m_{A u} / \Delta m_{S t}=m_{A u} / m_{S t}$ a tömegarány adta szorzótényező, amely egyezik az alkalmazott 
oldatokban található tömegaránnyal. FNG-sztreptavidin esetén a vastagságarány a következő: $\Delta d_{A u} /\left.\Delta d_{s z t}\right|_{F N G-s z t}=0.316 \cdot \rho_{s z t} / \rho_{A u}=1.64 \cdot 10^{-2}$, míg CG-sztreptavidin esetén az alábbi: $\Delta d_{A u} /\left.\Delta d_{s z t}\right|_{C G-s z t}=1.148 \cdot \rho_{s z t} / \rho_{A u}=5.98 \cdot 10^{-2}$. Ez azt eredményezi, hogy a következő $\left.\Delta d_{A u}\right|_{F N G-s z t}=0.02 \mathrm{~nm}$ és $\left.\Delta d_{A u}\right|_{C G-s z t}=0.08 \mathrm{~nm}$ átlagos aranyréteg vastagság értékek felelnek meg $\Delta d_{s z t}=1.32 \mathrm{~nm}$ sztreptavidin vastagság mellett a mért értékeknek (Függelék 1. táblázat).

A fentiekben meghatározott sztreptavidin és aranyréteg-vastagságokat feltételezve TMM számolásokat végeztem a 3-as és 4-es minták esetén. A számolások eredménye azt mutatja, hogy ezek a rétegvastagságok keskenyebb minimumgörbéknek felelnek meg kisebb poláris szögértéknél, azaz a mért viszonylag nagy $\Delta \varphi_{\text {csatolas }}^{3-a \text { minta } F N G-s z t}=3.2^{\circ}$ és $\Delta \varphi_{\text {csatolas }}^{4-e s \text { mintatCG-szt }}=3.59^{\circ}$ eltolódás nem modellezhető a fenti sztreptavidin-arany rétegvastagság

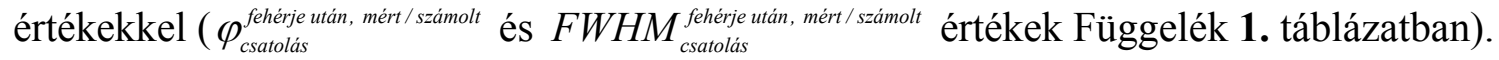

A jelöletlen sztreptavidin és FNG-sztreptavidin esetén mért csatolásból származó minimumhelyek összehasonlítása alapján megállapítható, hogy a FNG részecskék kissé megnövelik a minimumhely eltolódását, de a csúcs kiszélesedése jelentős (33(a) és (b) ábra, Függelék 1. táblázat). A kiszélesedés a 3-as minta felületére felvitt FNG-sztreptavidin konjugátumok véletlenszerű elhelyezkedésével magyarázható (32(g) és (h) ábra). A CGsztreptavidin esetén a szögeltolódás-félértékszélesség változás aránya erősen megnövekedik, nagyobb szögérték változás kísér ugyanakkora kiszélesedést, mint ami jelöletlen sztreptavidin esetén volt mérhető. Bevezetve a normalizált érzékenységi hányadost:

$$
S=\Delta \varphi / \triangle F W H M \quad .
$$

Megállapítható, hogy ez jelöletlen sztreptavidin és FNG-sztreptavidin esetén összemérhető a normalizált érzékenység: $S_{2-e \min t a} \approx S_{3-a s \min t a}$, míg a CG-sztreptavidin képes jelentősen megnöveli ezt a hányadost: $S_{2-e s \min t a}<<S_{4-e s \min t a}$.

A fehérjerétegben található aranyrészecskék mérete és elhelyezkedése jelentősen befolyásolhatja a rács-csatolt plazmon rezonancia-görbék minimumhelyeinek szögeltolódását és félértékszélességét, ezért a részecskék hatásának meghatározása céljából végeselem módszerrel modelleztük ezek közelterét. 


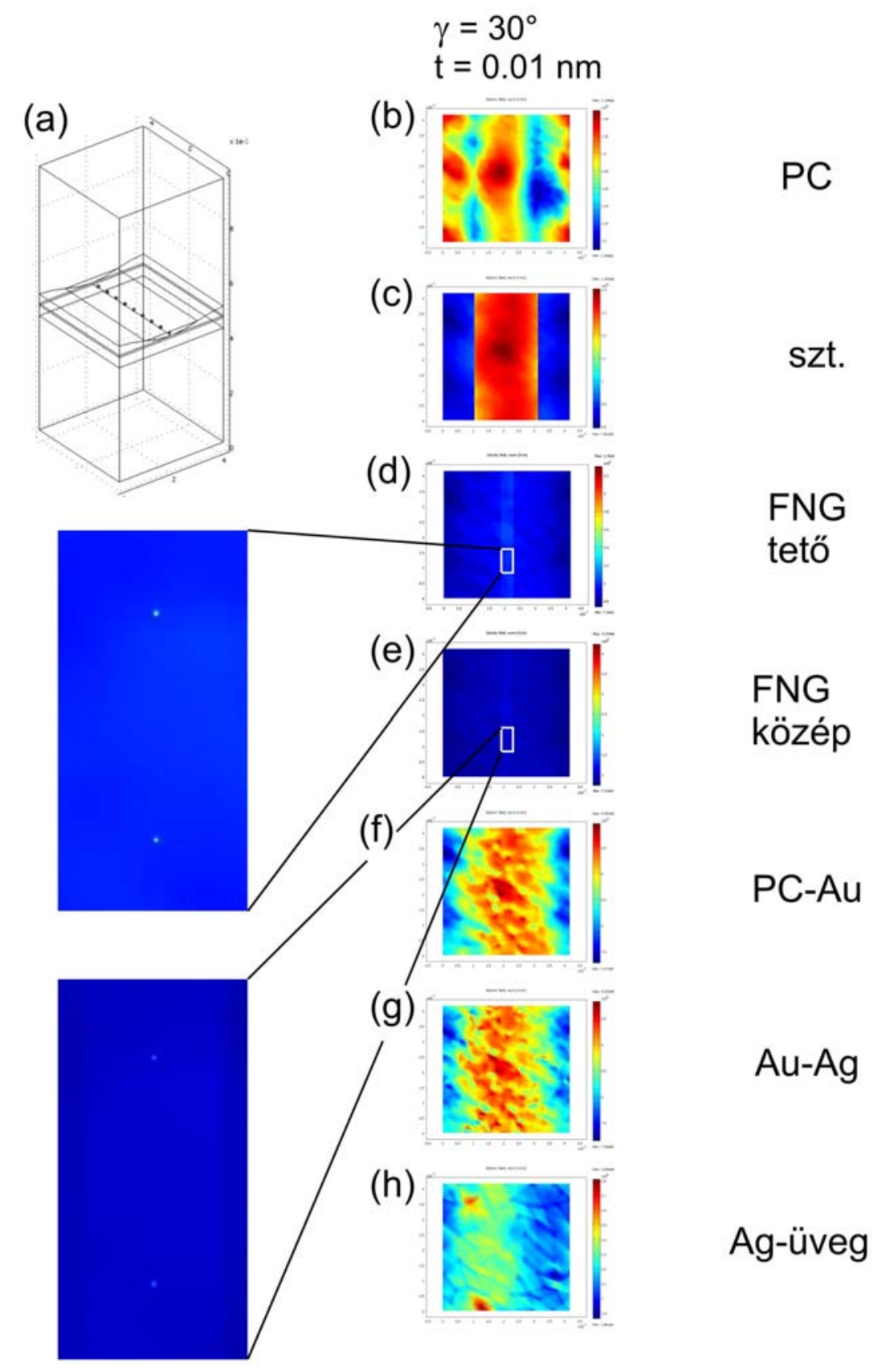

34. ábra. (a) A közeltér modellezésére használt geometria: a polimer vonalrács völgyei FNGsztreptavidinnel kitöltöttek, mint a 3-as minta esetén. A FNG arany részecskék $\mathrm{t}_{1}=0,01 \mathrm{~nm}$ távolságra vannak a völgy aljától, az azimuthális irány $\gamma=30^{\circ}$. Az elektromos tér eloszlása a (b) PC-levegő határfelületen, (c) a völgyeket borító sztreptavidin bevonat felső felületén, (d) az FNG arany részecskék felső (e) és középső részénél, (f) a PC réteg és arany felület találkozásánál, (g) az Au-Ag határfelületen (h) az Ag-üveg találkozásnál.

A rácsok profilját szinuszos keresztmetszetủ vonalas ráccsal közelítettem. A szinuszos rácsok völgyeit a $\Delta d_{s z t}=1.32 \mathrm{~nm}$ átlagos sztreptavidin vastagságnak megfelelő mennyiségü fehérjével töltöttem ki, a rács-csatolt plazmon rezonancia spektroszkópia mérésnek megfelelően. A $d_{F N G}=1 \mathrm{~nm}$ és $d_{C G}=10 \mathrm{~nm}$ átmérőjű aranyrészecskéket a völgyek aljától 
$t_{1}=0.01 \mathrm{~nm}$ és $t_{2}=1 \mathrm{~nm}$ távolságra helyeztem el. A részecskék számát a $\left.\Delta d_{A u}\right|_{F N G-s z t}=0.02 \mathrm{~nm}$ és $\left.\Delta d_{A u}\right|_{C G-s z t}=0.08 \mathrm{~nm}$ átlagos aranyréteg vastagság alapján határoztam meg a sztreptavidin aranytartalmának megfelelően (34. (a) ábra).

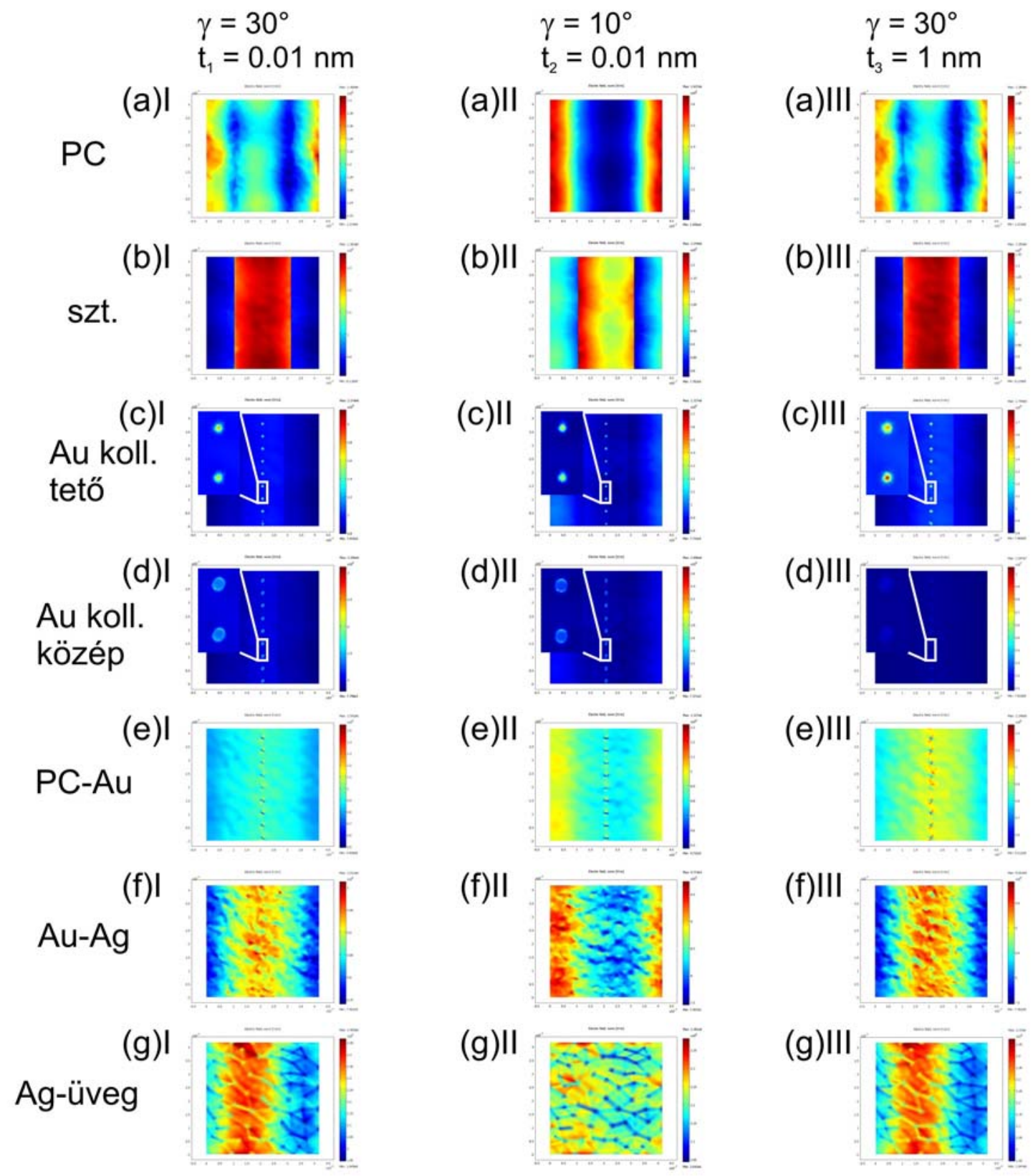

35. ábra. : A polimer vonalrács völgyei $10 \mathrm{~nm}$ átmérőjű arany kolloidrészecskékkel jelölt CG-sztreptavidinnel kitöltöttek, mint a 4-es minta esetén: I: $\gamma=30^{\circ}$ és II: $\gamma=10^{\circ}$ azimuthális irányok esetén a $C G$ részecskék a völgy aljától $\mathrm{t}_{1}=0,01 \mathrm{~nm}$ helyezkedtek el, a III esetben a: $\mathrm{t}_{2}=1 \mathrm{~nm}$ távra elhelyezett részecskéket is vizsgáltam az optimális azimuthális irányban. Az elektromos tér eloszlása a (b) PC-levegő határfelületen, (c) a völgyeket borító sztreptavidin bevonat felső felületén, (d) az arany kolloid részecskék felső (e) és középső részénél, (f) a PC réteg és arany felület találkozásánál, (g) az Au-Ag határfelületen (h) az Ag-üveg találkozásnál. 
A normalizált elektromos téreloszlást a rétegek határfelületénél vizsgáltam. A mérések szerint optimális $\gamma=30^{\circ}$ azimuthális irányú kivilágítás esetén erős periodikus elektromos tér erősítés figyelhető meg (34 és 35 III. ábra), továbbá az FNG részecskék jelenléte további gyenge térnövekményt okoz a rácsvölgyek mentén (34(d) és (e) ábra).

A 10 nm átméröjü arany kolloid gömbök esetén a FNG esetnél jóval nagyobb területen mérhető térnövekmény (35(c) és (d) ábrát összevetve 34(d) és (e) ábrával), ami azt mutatja, hogy biológiai anyagok detektálása folyamán ezek alkalmasabbak érzékenységnövelésre. A legnagyobb térnövekmény a kolloid gömbök tetején (35(c)I ábra) és közepén volt mérhető (35(d)I ábra), amikor a völgyek aljától $t_{1}=0.01 \mathrm{~nm}$ távolságra helyezkednek el és az azimuthális irány a mérésekkel korreláló $\gamma=30^{\circ}$ irány volt. Ez azt igazolja, hogy hatékony rács-csatolás esetén a $\mathrm{CG}$ részecskékben gerjesztett plazmonok lehetővé teszik az EM tér koncentrációját. Amikor az optimálistól eltérő $\gamma=10^{\circ}$ irányban világítottam ki a modellt, a periodikus intenzitásmoduláció a rácsvölgyekhez képest eltolódott (35(a)II)-(g)II ábrák), és a részecskék körüli elektromágneses tér koncentrációja is kevésbé határozott (35(c)II-(d)II ábrák), valamint a lokális plazmon terének iránya is megváltozott (35(d)II ábra). A CG részecskék a rács völgyének aljától $t_{2}=1 \mathrm{~nm}$ nagyobb távolságra való elhelyezése esetén kevésbé erős tér jön létre körülöttük, annak ellenére, hogy a $\gamma=30^{\circ}$ irányban világítjuk ki ezeket. Ez azt igazolja, hogy az aranyrészecskék helyzetének a biomolekula rétegen belül nagyon fontos szerepe van (35(a)II-(g)II ábrák) [T3]. 


\section{7. Összefoglalás}

Munkám során azt vizsgáltam, hogy fém és polikarbonát felületen előállított rácsok hogyan alkalmazhatóak biodetektálásra. Az egyszerű rácsfelülettől a bonyolultabb, részletgazdagabb felületek előállítása felé haladva kompozit maszk alapú kolloid litográfiás elrendezéssel kísérletileg vizsgáltam, hogy lineáris struktúra hogyan állítható elő és a mintázat méretparaméterei hogyan változtathatóak. Végeselem modellezéssel a maszkos elrendezésnél kevesebb lépésből álló kombinált litográfiás elrendezés lehetőségeit tanulmányoztam, mellyel az előző megoldásnál egyszerűbb és szintén szabályozható módon állítható elő lineáris struktúra. A plazmonikus struktúrákat tanulmányozva kerestem, hogy mely tulajdonságok esetében alkalmasak sztreptavidin detektálására.

Az elért eredményeket a következő tézispontokban foglaltam össze:

1.(a) Különböző összetételü ezüst és arany bimetál réteggel bevont üveghordozón készített $900 \mathrm{~nm}$ periódusú rácsok atomi erő mikroszkópos vizsgálatával igazoltam, hogy a felületen létrehozható struktúra minősége függ az egyes fémrétegek vastagságától [T1].

1.(b) A fedetlen és sztreptavidin molekula-réteggel bevont fémrácsok módosított Kretschmann-féle elrendezésben végzett szögfüggő plazmon rezonancia spektroszkópiai (SPRS) vizsgálatával kimutattam, hogy a periodikus felületi struktúrákat tartalmazó bimetál fémrétegek plazmonikus detektor-elemként alkalmazhatók [T1].

2.(a) Kimutattam, hogy a bimetál filmre forgatva bevonás módszerével felvitt vékony polikarbonát dielektrikum réteg mesterrácsos elrendezésben kivilágítása hatására kialakuló felületi topográfia moduláció hangolható a kísérleti paraméterekkel (lövésszám, energiasürüség, polarizáció) [T2].

2.(b) Igazoltam, hogy az s-polarizált fénnyel létrehozható lineáris polikarbonát-ráccsal fedett bimetál réteg plazmonikus detektor-elemként alkalmazható kis mennyiségü sztreptavidin plazmon rezonancia spektroszkópia módszerével történő kimutatására. SPRS vizsgálattal és végeselem módszerrel igazoltam, hogy a sztreptavidin molekula kolloidrészecskével történő jelölésével a detektálás érzékenysége növelhető [T3].

3.(a) A $416 \mathrm{~nm}$ és $833 \mathrm{~nm}$ periódusú lineáris polikarbonát rácsokra a forgatva bevonás módszerével felvitt $250 \mathrm{~nm}$ és $500 \mathrm{~nm}$ átméröjü Stöber-kvarc kolloid gömbök alkotta kompozit maszk lézeres megvilágításával igazoltam, hogy többlépéses kísérleti eljárással lineáris lyukmintázat hozható létre [T4]. 
3.(b) A lyukmintázat utólagos dielektrikum kolloid részecske- és polimer-réteggel történő bevonásával igazoltam, hogy a kompozit maszk alkalmazásával előállított szenzorfelület dielektrikum rétegek detektálására alkalmazható [T4].

4.(a) Arany filmre helyezett arany és Stöber-kvarc anyagú kolloid gömbök monorétegének kétnyalábos interferencia-mintázattal kivilágításának végeselem módszerrel történő modellezésével igazoltam, hogy optikai eljárással is létrehozható lineáris lyukmintázat. Kimutattam, hogy a $d$ távolságra elhelyezkedő gömbök monorétegének $(1,0,0)$ irányához képest az interferencia-maximumok irányát változtatva a gömbök közötti $[d / 2] /[\sqrt{3} d / 2]$ távolsággal összemérhető periódusú, egymástól $[d / \sqrt{3} d]$ távolságra elhelyezkedő nano-objektumok lineáris mintázatát lehet létrehozni. Kimutattam, hogy a kivilágító fény $400 \mathrm{~nm}$ vagy $532 \mathrm{~nm}$ hullámhosszától és cirkuláris vagy lineáris polarizációjától függetlenül kétnyalábos interferencia-mintázattal való kivilágítás esetén a gömbök alatti közeltér erősítése nagyobb, mint a homogén kivilágítással elérhető értékek [T5, T6].

4.(b) Arany gömb esetén igazoltam, hogy az 532 nm-es hullámhosszon való kivilágításakor a létrehozható struktúra mérete a gömbátmérővel csökken. A lyukak és lyukpárok alkotta hatszöges és négyszöges mintázatok spektrális hatásának végeselem modellezésével bizonyítottam, hogy a $\sim 10 \mathrm{~nm}$ átmérőjü a lyukak és a lyukakból képezett mintázat geometriája már kimutathatóan befolyásolja az objektumokat tartalmazó vékony aranyfilm transzmissziós spektrumát, amely a specifikus bioszenzorizációs alkalmazásokat elősegítheti [T5].

4.(c) Arany filmre helyezett 500, 250 és 100 nm átmérőjü Stöber-kvarc gömbök esetén igazoltam, hogy a homogén nyalábbal kivilágítás kör alakú nano-objektumokat eredményez cirkuláris polarizáció esetében mindkét vizsgált hullámhosszon, míg a lineáris polarizált nyaláb hatására létrejövő objektumok nagyobb ellipticitást mutatnak $532 \mathrm{~nm}$ hullámhosszon, mint 400 nm-en. Kétnyalábos interferencia-mintázattal való kivilágítást alkalmazva elliptikus lyukakból álló lineáris mintázat hozható létre lineáris polarizációval, cirkuláris polarizáció esetén pedig a köralakot jobban közelítő nanolyukak és nanoholdak együttes mintázata állítható elő. [T6]. 


\section{Summary}

\section{Introduction}

Surface plasmons are collective resonant electron oscillations induced by light illumination of a dielectric-conductor (metal in most cases) boundary. Plasmonics is a branch of photonics investigating these oscillations, studying the emergence, characteristics and means of their modification. The EM-field of surface plasmons decays exponentially if measured perpendicularly to the boundary and this decay length is smaller than the propagation length, which is in the order of $10 \mathrm{~nm}-100 \mu \mathrm{m}$ depending on the illuminating light wavelength and on material properties. Due to the development of miniaturization the fabrication of such small surface structures is possible, which can alter the resonance characteristics of plasmons. Based on these small features, surface structures can be fabricated which are able to function as plasmonic devices even though there are inherent energy losses caused by propagation.

The instruments based on the unique characteristics of plasmons have large field of applications. Wavelength-scaled plasmonic structures were demonstrated to act as like optical elements, e.g. flat mirrors. Plasmonic structures can be used in data storage, microscopy and for increasing the efficiency of photovoltaic elements. Another important filed of applications is the fabrication of plasmonic sensors to detect different biological materials, these are capable of detecting even single molecules. Significant part of surface features used in biosensors is the class of periodic structures, e.g. plasmonic crystals (which are analogous to photonic crystals) or plasmonic meta?-materials.

The wave vector of a plasmon is larger than of a photon having the same frequency according to the dispersion relation of the plasmon, so the plasmons can be generated only if this difference is compensated. This can be addressed in different ways, among them the most common experimental solution is the use of a prism. With application of a grating light can be coupled into and out from the plasmonic systems, meaning that plasmonic circuits can be fabricated. This leads to the development of electronic devices much smaller than the ones used nowadays, which is a future prospect for light-based photonic circuits.

The controlled fabrication of plasmonic structures is crucial for many applications of plasmonics, many scientific and technical problem can be solved with appropriate plasmonic patterns. Laser-based material processing methods are parallel techniques, large areas can be structured in a single step. In laser-based lithography methods the permanent surface modification depends on the parameters of the applied laser and on the material properties. 
The physical process responsible for surface structure development can be the ablation (material removal and/or relocation) or a photochemical change in the material (photoresist) or the combination of the two phenomena. The methods based on ablation usually are onestep and these are considered as fast and simple techniques, but the fabrication of complex structures is challenging. Complex structures can be prepared with multi-step lithography of photoresists. These in most cases require elaborate equipment and thorough knowledge, and appropriately high resolution structuring can be performed in high level clean room environments, which is not widely available. Structures with wavelength range size can be prepared using laser interference lithography methods, which can be used in different fields of science and industry. The disadvantage of these methods is that nanometric features can be made only via hardly controllable self-organized phenomena caused by the diffraction limit.

Colloid sphere lithography is capable of resulting in well defined small structures. The light illuminating such spheres is concentrated below them modifying the substrate surface. In most cases, the spheres are hexagonally closely packed on the surface, so the result inherits this symmetry. The result of the illumination is the function of the sphere and substrate material properties and of the illumination parameters. In multi-step processes the colloid particles or the structured surface is covered with additional material, but these patterns have always hexagonally symmetry. Fabrication of linear patterns is possible only with the use of masks ore with the alteration of the chemical forces between the spheres.

As a result plasmonic detectors investigation, at the beginning of the 1990s emerged the first commercial detectors based on surface plasmon resonance spectroscopy. More companies followed the Swedish Biacore, so thanks to the continuous developments, detection of wide variety of biomaterials ranging from allergens and cancer markers (Spreeta) through antibodies (Autolab Esprit) to bacteria (Biacore 3000) are possible. These devices measure the optical properties of a material circulated in a flow pipe and after appropriate calibration the amount of material is determined. With multichannel devices more measurements can be realized simultaneously, but these require complicate setup for materials circulation.

Plasmonic detectors based on the lab-on-chip designs can be less complicated. The concept of such a detector is that different small surface areas are prepared differently to observe a specific material, and the light in- and outcoupling is ensured, e.g. via plasmonic nanostructures. These detectors can operate even in dry environment and can be prepared via versatile lithographical procedures. 
Based on this idea, during my work I have studied whether metal and polycarbonate gratings can act as biodetectors. Advancing from the simple grating surfaces towards more complex design I have studied experimentally the fabrication of linear plasmonic structure prepared with the use of a composite mask. I have studied with finite element modeling the possibilities of an optical lithography method which has fewer steps, it is less complicated and is capable of controlling the linear structure. I have searched how the plasmonic structures can be used for the detection of streptavidin.

\section{Objectives}

Studying the literature concerning periodic and plasmonic structures one can conclude that application of complex structures consisting of wavelength-scaled arrays of components with size below the diffraction limit is very large, but there is demand for further development. The methods used to prepare such complex structures are generally time consuming and the high cost are not a marginal factor. Based on these, research for novel techniques for fabrication of periodic and complex structures is necessary.

The different fields of nanophotonics and nanoplasmonics require special complex structures. Several theoretical methods are available to describe the effect of plasmonic structures on the optical properties of a surface. The general us of nano- and plasmonic structures is preceded by the experimental and theoretical study of their properties, the testing of the surfaces as biosensors.

According to this, my objectives were as follows:

My first goal was to study the surface quality of gold-silver bimetal grating prepared with laser illumination, which is needed to determine the ideal layer thicknesses for biodetection. I intended to show with surface plasmon resonance spectroscopy (SPRS) that the bimetallic grating can be used to detect streptavidin.

My second objective was to determine those laser structuring parameters, which can be used to tune the surface morphology of a polymer layer spin-coated on bimetallic film. Using SPRS I aimed to study the use of polycarbonate gratings as biodetectors and to investigate the change of sensitivity due to the conjugation of gold particles to the streptavidin.

My third objective was the fabrication of a composite mask by spin-coating Stöbersilica colloid spheres on polymer master grating and with the illumination of this mask fabrication of linear arrays. I planned to test the fabricated linear array as a sensor for detection of dielectric materials. 
My fourth goal is the study of the illumination by two interfering beams of gold and Stöber-silica colloid sphere monolayers with the use of finite element modeling. I intended to examine the dependence of the structure parameters of the resulting pattern on the illumination conditions and monolayer characteristics. I planned to investigate theoretically the plasmonic properties of linear complex structures.

\section{Methods}

I used the two beam interference method to prepare gratings in bimetal films and in polycarbonate films spin-coated onto bimetal films. The use of simple components is the advantage of this method, low cost fabrication of appropriately variable structure is possible. The interference of two coherent beams having the same wavelength and plane of incidence results in a linear interference pattern. In experiments I used two setups to fabricate gratings. The first setup is based on the use of mirrors to produce an interference pattern on the substrate surface, the other is the master grating based arrangement. Considering the advantages and disadvantages of these methods, I used the first one to fabricate bimetal gratings which require higher fluence, and for lower fluence need of polycarbonate covered sample the master grating based arrangement was more suitable. The light source was the fourth harmonic beam of a Nd:YAG pulsed laser (Spectra Physics Quanta Ray Pro, $10 \mathrm{~Hz}$ ) with $\lambda_{\mathrm{SH}}=266 \mathrm{~nm}$ wavelength and $\tau=10 \mathrm{~ns}$ pulse length.

The sample substrate was an interferometrically flat NBK7 glass (Geodasy, EKSMA) and gold-silver bimetallic films were evaporated onto these having different thickness combinations. To prepare polymer gratings, a polycarbonate layer was spin-coated onto the bimetal film. The lower damage threshold of polycarbonate makes it possible to fabricate well-controlled gratings with relatively low laser fluence. The spin-coating technique was used to depose Stöber-silica colloid spheres into the valleys of the polycarbonate gratings. The adhesion of grating valleys and the periodic topography ensures that the colloid particles are well ordered. This complex mask consisting of colloid spheres in the grating valley was illuminated with $\mathrm{KrF}$ excimer laser. The generated linear hole array after atomic force microscope (AFM) and SPRS investigation was recovered with silica colloid spheres or polycarbonate. For the modeling of colloid sphere lithography I used gold and Stöber-silica particles, in the experiments I used the silica spheres.

In a modified Kretschmann-arrangement the attenuated total reflection based SPRS method was used to study the layer combinations and the fabricated samples were studied. The topography of the surfaces was measured with AFM. The resolution of modern AFMs is below the diffraction limit, enables to study the sample surfaces in such detail that with other 
methods is only partially available or not available at all. I used the tapping mode option during the measurement, in this configuration the cantilever oscillates above the sample surface without contact. This method is adequate to measure sensitive materials like biomaterials or even living cells. The phase map gives information on the different materials on the surface by mapping the change of the phase of cantilever oscillation compared to the driving signal.

The surfaces prepared were used to detect biomaterials, we studied detection of small amount of unlabeled streptavidin and streptavidin labeled with gold particles. The attachment of biomaterials was made always out of freshly prepared solutions. The non-covalent binding between streptavidin and biotin is strong, so the used amount of biotin determines the adhered amount of streptavidin, and thus the amount of labeling gold particles is controllable

Theoretical methods were used to analyze the measured SPRS spectra and to model the pattern available below interference illuminate colloid spheres. The finite element method is a numerical calculation procedure, which enables to calculate the solutions of predefined partial differential equations. The equations are solved at the nodes of a mesh, and the results are extrapolated to other regions. I used Fem to investigate illumination by two interfering beams of gold and Stöber-silica colloid sphere monolayers and to model the near-field effect of gold labeling particles conjugated to streptavidin molecules.

I used the analytical transfer matrix method (TMM) to help in the design and modeling of the surface structures and to analyze the measured SPRS resonance curves. Using the TMM method reflection and transmission of thin films and stack of thin films can be calculated. The essence of this method is that the reflection, transmission and absorption can be calculated at a boundary of two layers with an appropriate transfer matrix, for multiple layers a matrix for the whole system can be given.

\section{New scientific results}

I summarize the new scientific results as follows:

1.(a) Studying $900 \mathrm{~nm}$ periodic gratings prepared on glass substrate covered with bimetal layers consisting of silver and gold thin films with different thicknesses I have proven that the quality of the surface structure is a function of the composing metal layers thickness [T1].

1.(b) Based on the angle dependent surface plasmon resonance spectroscopy measurement in a modified Kretschmann-arrangement of bare and streptavidin ad-layer 
covered bimetal gratings I have shown that the periodically modulated bimetal films can be used as plasmonic detectors [T1].

2.(a) I have shown that the topographic modulation generated on a polycarbonate dielectric layer spin-coated onto bimetal thin film can be tuned by changing the experimental parameters (applied laser pulse number, fluence, polarization) in a master-grating based lithography setup [T2].

2.(b) I have proven that linear polycarbonate grating covered bimetal layers can be used as plasmonic detectors to observe small amount of streptavidin with surface plasmon resonance spectroscopy method. I proved with SPRS and finite element modeling that the labeling of streptavidin with colloidal gold particles enhances the sensitivity of detection [T3].

3.(a) I proven that linear pattern of holes can be generated using a multistep method by laser illumination of a composite mask consisting of $250 \mathrm{~nm}$ és $500 \mathrm{~nm}$ diameter Stöber-silica colloid spheres spin-coated into the valleys of a $416 \mathrm{~nm}$ and $833 \mathrm{~nm}$ periodic linear polycarbonate grating [T4].

3.(b) By recovering the linear hole-array with the polycarbonate and Stöber-silica I have proven that the surface fabricated with the composite mask can be used to detect dielectric layers [T4].

4.(a) I have proven with finite element modeling that the two-beam interference illumination of gold and Stöber-silica colloid sphere monolayers placed on thin gold films that linear hole-array can be generated via optical method. I have shown that by changing the orientation of the interference maxima measured to $(1,0,0)$ crystallographic direction of the monolayer of spheres placed at a $d$ distance between each other linear array of nanoobjects can be generated having period commensurate with $[d / 2] /[\sqrt{3} d / 2]$ and positioned at the $[d / \sqrt{3} d]$ distance along the maxima. I have shown that in case of illumination by two interfering beams the near-field under the spheres is always larger than in case of homogeneous illumination regardless $532 \mathrm{~nm}$ and $400 \mathrm{~nm}$ wavelength and the circular or linear polarization is applied [T5, T6].

4.(b) In case of gold spheres I have proven that the size of the features generated by $532 \mathrm{~nm}$ illumination the size of the structure decreases with the sphere diameter. With the finite element modeling of the transmittance spectra of hexagonal and linear patterns of single 
holes and hole doublets I have proven that the geometry of holes with $\sim 10 \mathrm{~nm}$ size and the array of these can alter the transmittance spectrum of the gold thin film containing them, which can be helpful in specific biosensor applications [T5].

4.(c) Illuminating Stöber-silica spheres having 500, 250 and $100 \mathrm{~nm}$ diameter with circularly polarized homogeneous beam the generated nano-.objects are circular regardless the wavelength, while for linear polarization these show larger ellipticity for $532 \mathrm{~nm}$ wavelength, than for $400 \mathrm{~nm}$. Using two-beam interference illumination linear arrays of elliptical holes can be generated with linearly polarized beams, while for circular polarization array of more cylindrical nanoholes and nano-crescents can be achieved [T6]. 


\section{Irodalomjegyzék}

\section{Tézispontok alapjául szolgáló publikációk:}

[T1] M. Csete, A. Kőházi-Kis, Cs. Vass, Á. Sipos, G. Szekeres, M. Deli, K. Osvay, Zs. Bor: "Atomic force microscopical and surface plasmon resonance spectroscopical investigation of sub-micrometer metal gratings generated by UV laser based two-beam interference in Au-Ag bimetallic layers”, Applied Surface Science, 254(19), p. 7662-7671 (2007).

[T2] M. Csete, Á. Sipos, A. Kőházi-Kis, A. Szalai, G. Szekeres, A. Mathesz, T. Csákó, K. Osvay, Zs. Bor, B. Penke, M. A. Deli, Sz. Veszelka, A. Schmatulla, O. Marti: "Comparative study of sub-micrometer polymeric structures: Dot-arrays, linear and crossed gratings generated by UV laser based two-beam interference, as surfaces for SPR and AFM based bio-sensing”, Applied Surface Science 254(4), p. 1194-1200 (2007).

[T3] Á. Sipos, H. Tóháti, A. Mathesz, A. Szalai, Sz. Veszelka, M. A. Deli, L. Fülöp, A. Köházi-Kis, M. Csete, Zs. Bor: "Effect of nanogold particles on coupled plasmon resonance on biomolecule covered prepatterned multilayers", Sensor Letters 8, p. 512-520 (2010).

[T4] Á. Sipos, H. Tóháti, A. Szalai, A. Mathesz, M. Görbe, T. Szabó, M. Szekeres, B. Hopp, M. Csete, I. Dékány: "Plasmonic structure generation by laser illumination of silica colloid spheres deposited onto prepatterned polymer-bimetal films", Applied Surface Science 225(10) p. 5138-5145 (2009).

[T5] M. Csete, Á. Sipos, A. Szalai, G. Szabó: "Theoretical Study on Interferometric Illumination of Gold Colloid Sphere Monolayers to Produce Complex Structures for Spectral Engineering”, IEEE Photonics Journal, 4(5) p. 1909-1921 (2012).

[T6] Á. Sipos, A. Szalai, M. Csete: “Integrated lithography to prepare periodic arrays of nano-objects" Applied Surface Science, online megjelent, DOI: 10.1016/j.apsusc.2012.11.078 p. 1-6. (2012).

\section{Felhasznált irodalom:}

[1] H. Raether: Surface plasmons on smooth and rough surfaces and on gratings (ed. G. Höhler) Springer, Berlin (1988).

[2] S. A. Maier: "Plasmonics - Towards Subwavelength Optical Devices", Current Nanoscience 1, p. 17-22 (2005).

[3] H. Ditlbacher, J. R. Krenn, G. Schider, A. Leitner, F. R. Aussenegg: "Two-dimensional optics with surface plasmon polaritons” Appl. Phys. Lett. 81, p. 1762-1764 (2002).

[4] J. Tominaga, T. Nakano: Optical Near-Field Recording - Science and Technology Springer, Berlin, Heidelberg, (2005). 
[5] A. V. Zayats, I. I. Smolyaninov, A. A. Maradudin: "Nano-optics of surface plasmon polaritons", Physics Reports 408, p. 131-314 (2005).

[6] H. A. Atwater, A. Polman: "Plasmonics for improved photovoltaic devices", Naturel Materials 9, p. 205-2013 (2010).

[7] J. Homola,Y. S. . Yee, G. Gauglitz: "Surface plasmon resonance sensors: review" Sensors and Actuators B 54 p. 3-15 (1999).

[8] K. Kneipp, Y. Wang, H. Kneipp, L. T. Perelman, I. Itzkan, R. R. Dasari, M. S. Feld: "Single molecule detection using surface-enhanced Raman scattering (SERS)", Phys. Rev. Lett. 78, p. 16671670 (1997).

[9] J. D. Joannopoulos, R. D. Meade, J. N. Winn: Photonic CrystalsV Molding the Flow of Light. Princeton University Press, Princeton, NJ (1995).

[10] E. Ozbay: "Plasmonics: Merging photonics and electronics at nanoscale dimensions", Science, 311(5758), p. 189-193 (2006).

[11] J. R. Sambles,G. W. Bradbery, F.Z. Yang: "Optical-excitation of surface-plasmons: an introduction” Contemporary Physics, 32, p. 173-183 (1991).

[12] R. H. Ritchie, E. T. Arakawa, J. J. Cowan, R. N. Hamm: "Surface-plasmon resonance effect in grating diffraction” Phys. Rev. Lett. 21, p. 1530-1533 (1968).

[13] B. D. Gates, Q. Xu, M. Stewart, D. Ryan, C. G. Wilson, and G. M. Whitesides, "New approaches to nanofabrication: Molding, printing, and other techniques”, Chem. Rev. 105, p. 1171-1196 (2005).

[14] L. Wu, Y. Zhong, C. T. Chan, K. S. Wong: "Fabrication of large area two- and threedimensional polymer photonic crystals using single refracting prism holographic lithography”, Applied Physics Letters 86, p. 241102 (2005).

[15] M. Csete, Zs. Bor: "Laser-induced periodic surface structure formation on polyethylene-terephthalate”, Applied Surface Science, 133(1-2), p. 5-16 (1998).

[16] M. Davidson, J. Tokarz, J. Gorrell: "Patterning thin metal films by dry reactive ion etching” US patent 2006/0035173 (2006).

[17] Z. Yu, P. Deshpande, W. Wu, J. Wang, S. Y. Chou: "Reflective polarizer based on a stacked double-layer subwavelength metal grating structure fabricated using nanoimprint lithography”, Appl. Phys. Lett. 77, p. $927-929$ (2000).

[18] H Jansen, H. Gardeniers, M. de Boer, M. Elwenspoek, J, Fluitman: "A survey on the reactive ion etching of silicon in microtechnology” J. Micromech. Microeng. 6 p. 14-28 (1996).

[19] P. Simon, J. Ihlemann: "Ablation of submicron structures on metals and semiconductors by femtosecond UV-laser pulses”, Applied Surface Science 109-110 p. 25 29 (1997). 
[20] Y. F. Lu, W. K. Choi, Y. Aoyagi, A. Kinomura, K. Fujii: "Controllable laser - induced periodic structures at silicon-dioxide/silicon interface by excimer laser irradiation” J. Appl. Phys. 80, p. 7052-6 (1996).

[21] M. Bolle, S. Lazare "Large scale excimer laser production of submicron periodic structures on polymer surfaces” Applied Surface Science 69, p. 31-37 (1993).

[22] C. Daniel, A. Lasagni, M. Müklich: "Stress and texture evolution of Ni/Al multi-film by laser interference irradiation”, Surf. Coat. Tech. 180-181, p. 478-482 (2004).

[23] Y. Nakata, T. Okada, M. Maeda: "Lithographical laser ablation using femtosecond laser”, Appl. Phys. A 79, p. 1481-1483 (2004).

[24] J.H. Klein-Wiele, J. Bekesi, P. Simon: "Sub-micron patterning of solid materials with ultraviolet femtosecond pulses”, Appl. Phys. A 79, p. 775-778 (2004).

[25] M.K. Kelly, J. Rogg, C.E. Nebel, M. Stutzmann, S. Kátai: "High-resolution thermal processing of semiconductors using pulsed-laser interference patterning”, Phys. Status Solidi A 166, p. 651-657 (1998).

[26] J. C. Hulteen, R. P. Van Duyne, "Nanosphere lithography: A materials general fabrication process for periodic particle array surfaces" J. Vac. Sci. Technol. A, 13, p. $1553-1558$ (1995).

[27] B. S. Luk'yanchuk, N. Arnold, S. M. Huang, Z. B. Wang, M. H. Hong: "Threedimensional effects in dry laser cleaning”, Appl. Phys. A. 77, p 209-215 (2003).

[28] A. Plech, P. Leiderer, J. Boneberg: "Femtosecond laser near-field ablation", Laser Photon. Rev. 3, p. 435-451 (2009).

[29] D. Bauerle: Laser Processing and Chemistry, Springer-Verlag, Berlin (2000).

[30] M. H. Wu, K. E. Paul, and G. M. Whitesides, "Patterning flood illumination with microlens arrays”, Appl. Opt. 41, p. 2575 2585, (2002).

[31] G. C. Schatz: "Using theory and computation to model nanoscale properties", Proc. Nat. Acad. Sci. USA 104, p. 6885-6892 (2007).

[32] M. Rycenga, P. H. C. Camargo, Y. Xia: "Template-assisted self-assembly: a versatile approach to complex micro- and nanostructures”, Soft Matter 5, p. 1129-1136 (2009).

[33] S. K. Smoukov, S. Gangwal, M. Marquez, O.D. Velev: "Reconfigurable responsive structures assembled from magnetic Janus particles”, Soft Matter 5, p. 1285-1292 (2009).

[34] I Kretzschmar, J. H. K. Song: "Surface-anisotropic spherical colloids in geometric and field confinement" Current Opinion in Colloid \& Interface Science 16, p. 84-95 (2011).

[35] J. H. Moon, W. S. Kim, J-W. Ha, S. G. Jang, S-M. Yang, J-K. Park: "Colloidal lithography with crosslinkable particles: fabrication of hierarchical nanopore arrays", Chemical Communications 32, p. 4107-4109 (2005). 
[36] D. Yuan, A. Lasagni, J. L. Hendricks, D. C. Martin, S. Das: "Patterning of periodic nano-cavities on PEDOT-PSS using nanosphere-assisted near-field optical enhancement and laser interference lithography”, Nanotechnology 23, p. 015304 (2012).

[37] E. Kretschmann, H. Raether: "Radiative decay of nonradiative surface plasmons excited by light”, Z. Naturforsch. A 23, p. 2135-2136 (1968).

[38] A. Otto: "Exitation of nonradiative surface plasma waves in silver by the method of frustrated total reflection”, Z. Phys. 216, p. 398-410 (1968).

[39] B. Hecht, H. Bielefeldt, L. Novotny, Y. Inouye, D.W. Pohl: "Local excitation, scattering, and interference of surface plasmons", Phys. Rev. Lett. 77, p. 1889-1892 (1996).

[40] W.L. Barnes, T.W. Preist, S.C. Kitson, J.R. Sambles: "Physical origin of photonic energy gaps in the propagation of surface plasmons on gratings", Phys. Rev. B 54(9), p. 6227 (1996).

[41] L.A. Moraga, R. Labbe: "Plasmons on a randomly rough surface", Phys. Rev. B 41, p. 10221-10223 (1990).

[42] J.J. Burke, G.I. Stegeman, T. Tamir: "Surface-polariton-like waves guided by thin, lossy metal films", Phys. Rev. B 33 p. 5186-5201 (1986).

[43] Z. Schlesinger, A.J. Sievers: "Infrared surface wave interferometry", Appl. Phys. Lett. 36, p. 409-412 (1980).

[44] T.W. Ebbesen, H.J. Lezec, H.F. Ghaemi, T. Thio, P.A. Wolff: “Extraordinary optical transmission through sub-wavelength hole arrays”, Nature 391, p.667-669 (1998).

[45] N. Félidj, J. Aubard, G. Lévi, J.R. Krenn, G. Schider, A. Leitner, F.R. Ausenegg: "Enhanced substrate-induced coupling in two-dimensional gold nanoparticle arrays", Phys. Rev. B 66, p. 245407 (2002).

[46] M. Quinten, A. Leitner, J.R. Krenn, F.R. Aussenegg: "Electromagnetic energy transport via linear chains of silver nanoparticles”, Opt. Lett. 23, p. 1331-1333 (1998).

[47] J. R. Krenn, A. Dereux, J. C. Weeber, E. Bourillot Y. Lacroute, J. P. Goudonnet, G. Schider, W. Gotschy, A. Leitner, and F. R. Aussenegg: "Squeezing the optical near-field zone by plasmon coupling of metallic nanoparticles”, Phys. Rev. Lett. 82, p. 259-2593 (1999).

[48] A. Degiron, H. Lezec, W. L. Barnes, T. W. Ebbesen: "Effects of hole depth on enhanced light transmission through subwavelength hole arrays" Appl. Phys. Lett. 81, p. 4327-4329 (2002).

[49] L. Martín-Moreno, F. J. Garcia-Vidal, H. J. Lezec, K. M. Pellerin, T. Thio, J. B. Pendry, T. W. Ebbesen: "Theory of extraordinary optical transmission through subwavelength hole arrays”, Phys. Rev. Lett. 86, p. 1114-1117 (2001). 
[50] N. Bonod, S. Enoch, L. Li, E. Popov, M. Nevière: "Resonant optical transmission through thin metallic films with and without holes", Opt. Expr. 11, p. 482-490 (2003).

[51] A.P. Hibbins, J.R. Sambles, C.R. Lawrence: "Azimuth-angle-dependent reflectivity data from metallic gratings", J. Mod. Optics 45, p. 1019-1028 (1998).

[52] M. Csete, A. Kőházi-Kis, V. Megyesi, K. Osvay, Zs. Bor, M. Pietralla, O. Marti: "Coupled surface plasmon resonance on bimetallic films covered by sub-micrometer polymer gratings”, Org. Electronics 8, p. 148-160 (2007).

[53] W. L. Barnes, A. Dereux, T. W. Ebbesen: "Surface plasmon subwavelength optics", Nature 424, p. 824-830 (2003).

[54] J. Homola: "Present and future of surface plasmon resonance biosensors", Anal. Bioanal. Chem. 377(3), p. 528-539 (2003).

[55] P. I. Nikitin, A. A. Beloglazov, V. E. Kochergin, M. V. Valeiko, T. I. Ksenevich: "Surface plasmon resonance interferometry for biological and chemical sensing", Sens. and Act. B: Chem. 54(1-2), p. 43-50 (1999).

[56] S. Puderbach, S. Herminghaus, P. Leiderer: "Investigation of laser desorption of thin dielectric films using optically excited surface plasmons”, Phys. Lett. A 130, p. 401-404 (1988).

[57] D.C. Cullen, R.G.W. Brown, C.R. Lowe: "Detection of immuno-complex formation via surface plasmon resonance on gold-coated diffraction gratings", Biosensors 3, p. 211-225 (1987-1988).

[58] R. Nakamura, H. Muguruma, K. Ikebukuro, S. Sasaki, R. Nagata, I. Karube, H. Pedersen: "A Plasma-Polymerized Film for Surface Plasmon Resonance Immunosensing”, Anal. Chem. 69(22), p. 4649-4652 (1997).

[59] J. Homola, I. Koudela, S. S.Yee: "Surface plasmon resonance sensors based on diffraction gratings and prism couplers: sensitivity comparison", Sens. and Act. B: Chem. 54(1-2), p. 16-24 (1999).

[60] C.R. Yonzon, E. Jeoung, S. Zou, G.C. Schatz, M. Mrksich, R.P. Van Duyne: “A Comparative Analysis of Localized and Propagating Surface Plasmon Resonance Sensors: The Binding of Concanavalin A to a Monosaccharide Functionalized SelfAssembled Monolayer", J. Am. Chem. Soc. 126, p. 12669-12676 (2004).

[61] Dintinger, S. Klein, F. Bustos,W.L. Barnes, T.W. Ebbesen: "Strong coupling between surface plasmon-polaritons and organic molecules in subwavelength hole arrays", Phys. Rev. B 71, p. 035424 (2005).

[62] J. V. Coe, K. R. Rodriguez, S. Teeters-Kennedy, K. Cilwa, J. Heer, H. Tian, S. M. Williams: "Metal Films with Arrays of Tiny Holes: Spectroscopy with Infrared Plasmonic Scaffolding”, J. Phys. Chem. C 111, p. 17459-17472 (2007). 
[63] J. S. Mitchell, Y. Wu, C. J. Cook, L. Main: "Sensitivity enhancement of surface plasmon resonance biosensing of small molecules" Anal. Biochem. 343, p. 125-135 (2005).

[64] S. J. Oldenburg, C. C. Genick, K. A. Clark, D. A. Schultz: "Base pair mismatch recognition using plasmon resonant particle labels”, Anal. Biochem. 309, p. 109-116 (2002).

[65] Homola, J. Surface Plasmon Resonance Based Sensors, Springer, Berlin, Germany, (2006).

[66] C. Nylander , B. Liedberg, T. Lind: "Gas detection by means of surface plasmon resonance”, Sens. and Act. 3, p. 79-88 (1982).

[67] C.A. Meeusen, E.C. Alocilja, W. N. Osburn: "Detection of E. coli O157: H7 using a miniaturized surface plasmon resonance biosensor", W. N. Trans. ASAE 48, p. 2409-2416 (2005).

[68] F. Fernández, K. Hegnerová, M. Piliarik, F. S. Baeza, J. Homola, M.-Pilar Marco: “A label-free and portable multichannel surface plasmon resonance immunosensor for on site analysis of antibiotics in milk samples", Biosensors and Bioelectronics 26, p. 1231-1238 (2010).

[69] H.M. Phillips, D.L. Callahan, R. Sauerbrey, G. Szabó, Z. Bor. "Direct laser ablation of sub-100 nm line structures into polyimide” Applied Physics A 54 p. 158-165 (1992).

[70] W. Stöber, A. Fink, E. Bohn: "Controlled growth of monodisperse silica spheres int he micron size range”, Journal of Colloid Interface Science 26, p. $62-69$ (1968).

[71] I. Dékány, J. Németh, M. Szekeres, R. Schoonheydt: "Surfacial, liquid sorption and monolayerforming properties of hydrophilic and hydrophobic Stöber silica particles", Colloid Polymer Science 282, p. 1-6 (2003).

[72] M. Szekeres, O. Kamalin, R. A. Schoonheydt, K. Wostyn, K. Clays, A. Persoons, I. Dékány: "Ordering and optical properties of monolayers and multilayers of silica spheres deposited by the Langmuir-Blodgett method", Journal of Materials Chemistry 12, p. 3268-3274 (2002).

[73] G. Binnig, C. F. Quate, and Ch. Gerber: “Atomic Force Microscope”, Physical Review Letters 56, p. 930-933 (1986).

[74] M. Stark, C. Möller, D. J. Müller, R. Guckenberger: "From Images to Interactions: High-Resolution Phase Imaging in Tapping-Mode Atomic Force Microscopy”, Biophys. Journ. 80, p. 3009-3018 (2001).

[75] A. Mechler, J. Kokavecz, P. Heszler, R. Lal: "Surface energy maps of nanostructures: Atomic force microscopy and numerical simulation study", Appl. Phys. Lett. 82, p. 3740-3743 (2003).

[76] E. Ruska: "The development of the electron microscope and of electron microscopy", Bioscience Reports 7, p. 607-629 (1987). 
[77] M. von Ardenne: „Das Elektronen-Rastermikroskop. Theoretische Grundlagen” Zeitschrift für Physik 109(9-10), p. 553-572 (1939).

[78] M. von Ardenne, Manfred: „Das Elektronen-Rastermikroskop. Praktische Ausführung”, Zeitschrift für technische Physik 19, p. 407-416 (1938).

[79] M. A. Ordal, L. L. Long, R. J. Bell, S. E. Bell, R. R. Bell, R. W. Alexander Jr., C. A. Ward: "Optical properties of the metals $\mathrm{Al}$, Co, Cu, $\mathrm{Au}, \mathrm{Fe}, \mathrm{Pb}, \mathrm{Ni}, \mathrm{Pd}, \mathrm{Pt}, \mathrm{Ag}$, Ti, and $\mathrm{W}$ in the infrared and far infrared”, Appl. Opt. 22 p. 10991120 (1983).

[80] M. Born, E. Wolf: "Principles of optics : electromagnetic theory of propagation, interference and diffraction of light” 6. kiadás, Pergamon, Oxford- New York (1989).

[81] J. Prikulis, P. Hanarp, L. Olofsson, D. Sutherland, and M. Käll: “Optical spectroscopy of nanometric holes in thin gold films”, Nano Lett., 4(6), p. 1003-1007 (2004).

[82] W. J. Parsons, E. Hendry, C. B. Burrows, B. Auquieá, J. R. Sambles, and W. L. Barnes: "Localized surface-plasmon resonances in periodic nondiffracting metallic nanoparticle and nanohole arrays", Phys. Rev. B, Condens. Matter Mater. Phys. 79, p. $073412(2009)$.

[83] B. Sepúlveda, Y. Alaverdyan, J. Alegret, M. Ka" 11, and P. Johansson, "Shape effects in the localized surface plasmon resonance of single nanoholes in thin metal films", Opt. Exp. 16, p. 5609-5616 (2008).

[84] R. Gordon, A. G. Brolo, A. McKinnon, A. Rajora, B. Leathem, and K. L. Kavanagh, "Strong polarization in the optical transmission through elliptical nanohole arrays", Phys. Rev. Lett. 92, p. 037401 (2004).

[85] F. J. G. De Abajo: "Light scattering by particle and hole arrays", Rev. Mod. Phys 79, p. 1267-1290 (2007).

[86] D. Pacifici, H. J. Lezec, L. A. Sweatlock, R. J. Walters, H. A. Atwater: "Universal optical transmission features in periodic and quasiperiodic hole arrays", Opt. Exp. 16, p. 9222-9238 (2008). 


\section{Köszönetnyilvánítás}

Elsősorban Dr. Csete Mária témavezetőmnek szeretném megköszönni, hogy a kutatás során türelmesen segített, támogatott, fáradtságot sosem kímélve. Hálás vagyok, hogy a rengeteg tanulás mellett nemcsak szakmai élményt jelentett a közös munka.

Köszönöm Dr. Bor Zsoltnak, Dr. Szabó Gábornak és Dr. Rácz Bélának hogy biztosították a doktori fokozatszerzéshez szükséges feltételeket. Külön köszönöm Dr. Osvay Károlynak, hogy szegedi indulásomat szakdolgozat témavezetőmként segítette majd közös munkánk során támogatta.

Köszönöm kolozsvári mentoromnak, témavezetőmnek Dr. Karácsony Jánosnak, hogy az optika megszerettetése mellett segítette a lézeres kutatás felé tett első lépéseimet.

Köszönöm Szalai Anikónak a rengeteg segítséget és a türelmet, Szekeres Gábornak, Mathesz Annának, az AFM és ATR mérésekben nyújtott segítségüket.

Hálás vagyok az MTA Szegedi Biológiai Központból Dr. Deli Máriának és Dr. Veszelka Szilviának a biológiai anyagok elkészítésében és felvitelében nyújtott támogatásukért.

Köszönettel tartozom Dr. Dékány Imrének, Dr. Szekeres Mártának, Dr. Szabó Tamásnak és Ábrahám Nórának a kolloid részecskék előállításában nyújtott támogatásért

Köszönet illeti a TeWaTi kutatócsoport jelenlegi és egykori munkatársait, közöttük is Dr. Kurdi Gábort, Dr. Görbe Mihályt, Dr. Merő Márkot, Dr. Börzsönyi Ádámot, Dr. Vass Csabát, Jójárt Pétert, Balogh Imrét, Kiss Miklóst, Kiss Bálintot, Péter Viktóriára és Verseghy Veronikát, hogy gondoskodtak a jó hangulatról és a mindennapok könnyebbé tételében társaim voltak.

Köszönöm Fazakas Csillának, Végh Gergőnek, Vass Istvánnak hogy szegedi családként számíthatok rájuk.

Szeretném megköszönni szüleimnek és testvéreimnek támogatásukat a sokszor nagynak távolság ellenére.

Fel sem tudom sorolni, mi mindent köszönök feleségemnek.

Jelen kutatási eredmények megjelenését az Országos Tudományos Kutatási Alapprogramok (OTKA) K75149 és CNK-78549 azonosítószámú, valamint „Az SZTE Kutatóegyetemi Kiválósági Központ tudásbázisának kiszélesítése és hosszú távú szakmai fenntarthatóságának megalapozása a kiváló tudományos utánpótlás biztosításával" című, TÁMOP-4.2.2/B-10/1-2010-0012 azonosítószámú projekt támogatta. Az értekezésemben bemutatott projektek az Európai Unió támogatásával, az Európai Szociális Alap társfinanszírozásával valósultak meg. 


\section{Függelék}

\begin{tabular}{|c|c|c|c|c|c|c|c|c|c|c|c|c|c|c|c|c|}
\hline \multirow[t]{2}{*}{ Minta } & $\varphi_{\text {csatolás }}^{\text {fehérjelött }}$ & \multicolumn{2}{|c|}{$\varphi_{\text {csatolás }}^{\text {fehérjeután }}$} & \multicolumn{2}{|c|}{$\Delta \varphi_{\text {csatolás }}$} & \multicolumn{2}{|c|}{$F W H M_{\text {csatolás }}^{\text {fehérjelöt }}$} & \multicolumn{2}{|c|}{$F W H M_{\text {csatolás }}^{\text {fehérjeután }}$} & \multicolumn{2}{|c|}{$\Delta F W H M_{\text {csatolas }}$} & \multicolumn{2}{|c|}{$\Delta \varphi_{\text {csatolás }} / \Delta F W H M_{\text {csatolás }}$} & $\Delta d_{p+b p}$ & $\Delta d_{s z t}$ & $\Delta d_{A u}$ \\
\hline & $\left({ }^{o}\right)$ & ( & ) & & ) & & o) & & & ( & & $\mathrm{S}$ & & $(\mathrm{nm})$ & $(\mathrm{nm})$ & $(\mathrm{nm})$ \\
\hline minta & mért & mért & szám. & mért & szám. & mért & szám. & mért & szám. & mért & szám. & mért & szám. & szám. & szám. & szám. \\
\hline Chip_1 & 51.04 & 53.52 & 53.52 & 2.48 & 2.48 & 6.72 & 4.82 & 8.64 & 6.1 & 1.92 & 1.28 & 1.29 & 1.94 & 6.06 & 0 & 0 \\
\hline Chip_2 & 50.96 & 54 & 54 & 3.04 & 3.04 & 7.2 & 4.78 & 9.44 & 6.34 & 2.24 & 1.56 & 1.36 & 1.95 & 6.06 & 1.32 & 0 \\
\hline Chip_3 & 49.68 & 52.88 & 52.4 & 3.2 & 2.72 & 4.96 & 4.14 & 8 & 5.5 & 3.04 & 1.36 & 1.05 & 2.01 & 6.06 & 1.32 & 0.02 \\
\hline
\end{tabular}

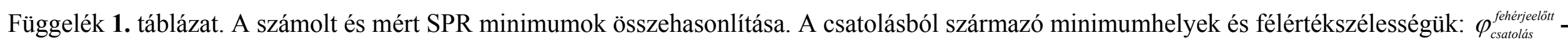

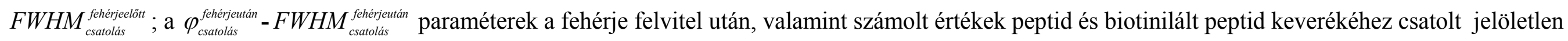

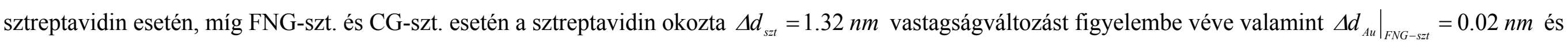

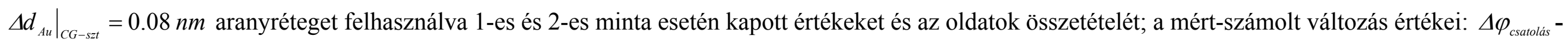

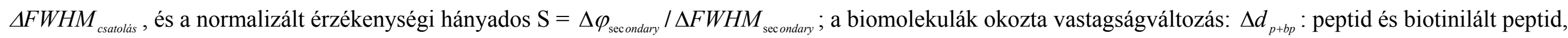
és sztreptavidin esetén, $\Delta d_{A u}$ átlagos aranyréteg változás a TMM számítások alapján. 